\title{
\#USGS
}

science for a changing world

Prepared in cooperation with the

National Exposure Research Laboratory, U.S. Environmental Protection Agency, Athens, Georgia, and the North Carolina Department of Environment and Natural Resources, Division of Water Quality, Groundwater section

\section{Geochemistry and Characteristics of Nitrogen Transport at a Confined Animal Feeding Operation in a Coastal Plain Agricultural Watershed, and Implications for Nutrient Loading in the Neuse River Basin, North Carolina, 1999-2002}
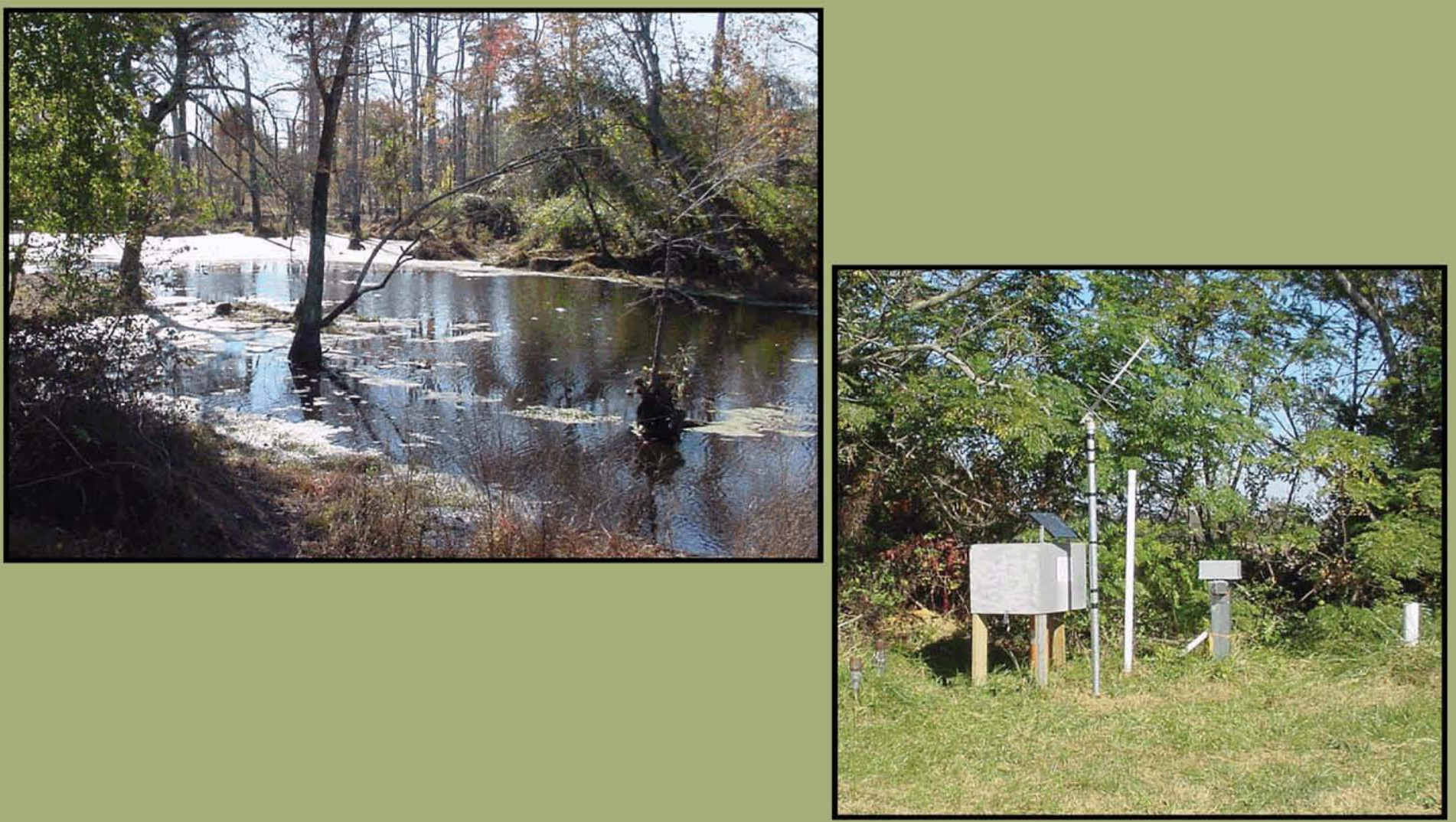

Scientific Investigations Report 2004-5283 
Cover photographs. Left: Sandy Run near the Lizzie Research Station, Greene County, North Carolina. Right: Ground-water sampling site L18 at the Lizzie Research Station. 
Geochemistry and Characteristics of Nitrogen Transport at a Confined Animal Feeding Operation in a Coastal Plain Agricultural Watershed, and Implications for Nutrient Loading in the Neuse River Basin, North Carolina, 1999-2002

By T.B. Spruill, A.J. Tesoriero, H.E. Mew, Jr., K.M. Farrell, S.L. Harden, A.B. Colosimo, and S.R. Kraemer

Prepared in cooperation with the National Exposure Research Laboratory, U.S. Environmental Protection Agency, Athens, Georgia, and the North Carolina Department of Environment and Natural Resources, Division of Water Quality, Groundwater Section

Scientific Investigations Report 2004-5283 


\title{
U.S. Department of the Interior Gale A. Norton, Secretary
}

\author{
U.S. Geological Survey \\ Charles G. Groat, Director
}

\section{U.S. Geological Survey, Reston, Virginia: 2005}

For sale by U.S. Geological Survey, Information Services

Box 25286, Denver Federal Center

Denver, CO 80225

\begin{abstract}
For more information about the USGS and its products:
Telephone: 1-888-ASK-USGS

World Wide Web: http://www.usgs.gov/

Any use of trade, product, or firm names in this publication is for descriptive purposes only and does not imply endorsement by the U.S. Government.

Although this report is in the public domain, permission must be secured from the individual copyright owners to reproduce any copyrighted materials contained within this report.
\end{abstract}

Research for this report was funded in part by the U.S. Environmental Protection Agency under Interagency Agreement DW14938792-01 to the U.S. Geological Survey; however, the report does not necessarily reflect the views of the Agency and no official endorsement should be inferred.

Suggested citation:

Spruill, T.B., Tesoriero, A.J., Mew, H.E., Jr., Farrell, K.M., Harden, S.L., Colosimo, A.B., and Kraemer, S.R., 2005, Geochemistry and characteristics of nitrogen transport at a confined animal feeding operation in a Coastal Plain agricultural watershed, and implications for nutrient loading in the Neuse River Basin, North Carolina, 1999-2002: U.S. Geological Survey Scientific Investigations Report 2004-5283, 57 p. 


\section{Contents}

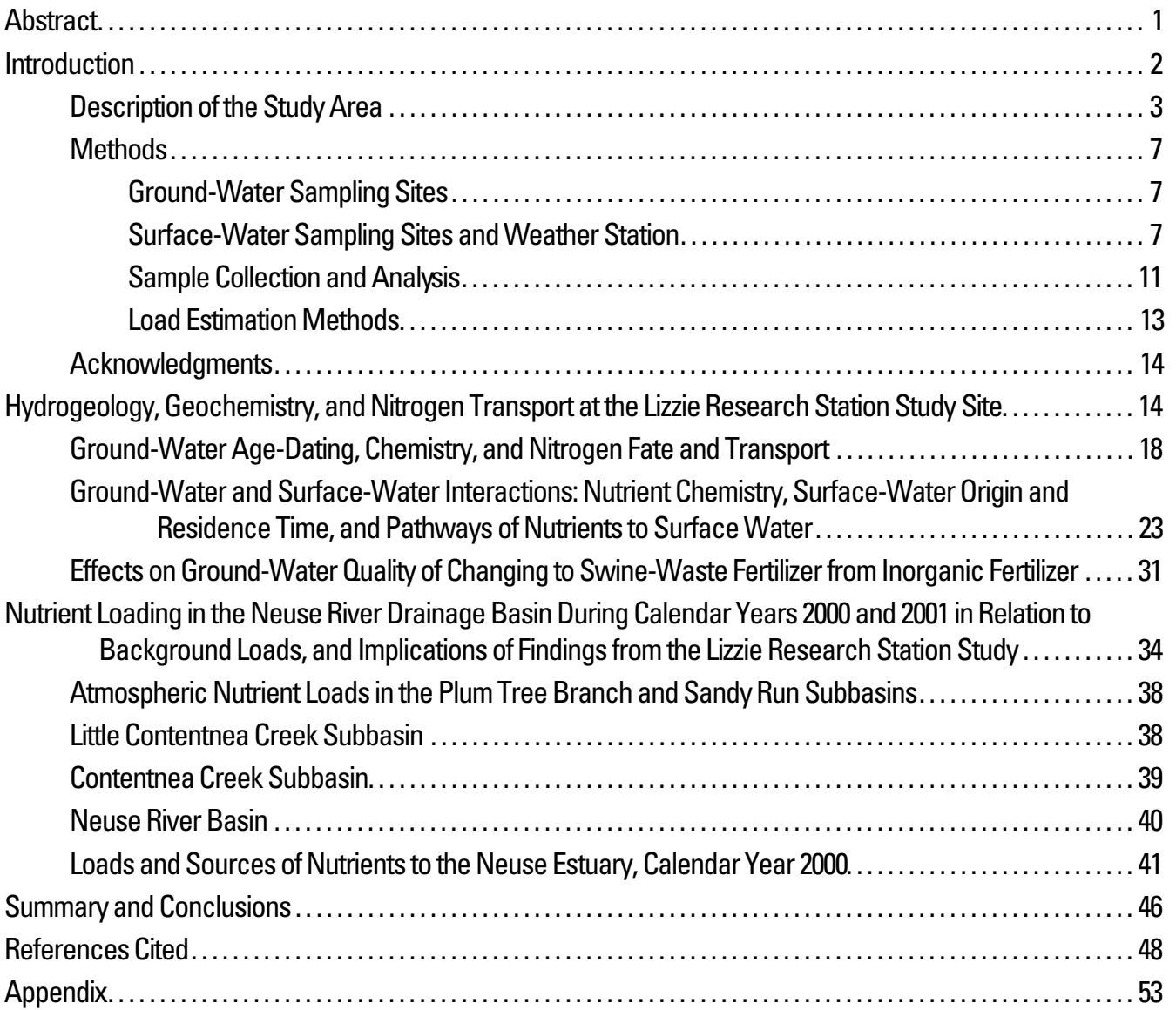

\section{Figures}

1. Locations of Lizzie Research Station and multimedia integrated modeling system

(MIMS) sampling sites in the Neuse River basin, North Carolina ......................... 4

2. Locations of surface-water and ground-water sampling sites at the Lizzie Research Station,

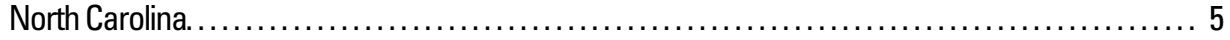

3. Photograph of weather station at the Lizzie Research Station, North Carolina ................. 11

4. Cross sections showing conceptual models of (A) stratigraphy and (B) hydrogeologic units of the Lizzie Research Station, North Carolina .................................... 15

5. Piezometric head values and contours and flow directions for the (A) surficial and (B) Yorktown aquifers on December 13, 2000, at the Lizzie Research Station, North Carolina ................ 16

6. Piezometric head values and contours along (A) cross-section A-A' and (B) cross-section B-B' . . 17

7. (A) Recharge dates and isopleths using chlorofluorocarbon concentrations, (B) isopleths and tritium concentrations, and (C) silica concentrations in ground water along transect $A-A^{\prime} \ldots \ldots \ldots 19$

8. Tritium concentrations in ground-water samples plotted against recharge year .............. 20

9. Ground-water residence time interpreted from chlorofluorocarbon (CFC) concentrations plotted against silica concentrations in samples from the Lizzie Research Station, North Carolina. 
10. Delineation of terminal electron-accepting processes along transect A-A'. Nitrate and excess

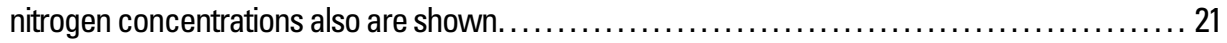

11. Sequence of oxidation-reduction reactions involved with oxidation of carbon (electron donor) and terminal electron acceptors preferred by bacteria in the saturated zone ................ 21

12. Dissolved argon and nitrogen concentrations in ground water......................... 22

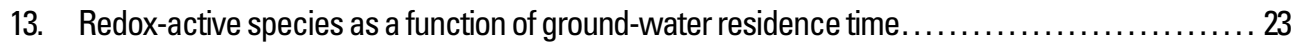

14. Nitrate and ammonium concentrations, phosphorus, and discharge for (A) Middle Swamp

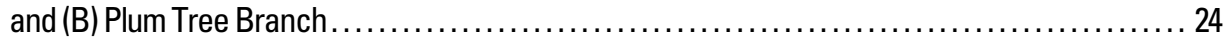

15. Trilinear diagrams of water chemistry in ground water, streams, and artificial drainages at the Lizzie Research Station, North Carolina ..................................... 28

16. Concentrations of silica in ground- and surface-water samples collected at the Lizzie Research Station, North Carolina.

17. Terminal electron-accepting zones along transect $L 2$ to Plum Tree Branch near site FP and concentrations of $(\mathrm{A})$ methane, iron, dissolved oxygen, and nitrate; and (B) silica, dissolved organic carbon, nitrate, and ammonium ................................ 30

18. Percent of nitrate flux increase along Plum Tree Branch reach from S7 to S2 that is attributed to tile drain SR5-T1, and discharge at Plum Tree Branch at S2 ........................ 31

19. Chemical constituent concentrations in ground water from wells $L 2$ and $L 6$ at the Lizzie Research Station, North Carolina, for 1995 (before swine-waste spray was used) and 1999 (after 4 years of swine-waste spraying).

20. Nitrite-plus-nitrate concentrations in ground-water samples from well L6 at the Lizzie Research Station, North Carolina, 1995-2003. 33

21. Concentrations of nitrite plus nitrate in ground water from shallow aquifers beneath four areas with selected land uses in the Coastal Plain of North Carolina ...

22. Concentrations of nitrate in fields fertilized with conventional inorganic fertilizer, sprayed swine waste, and wastewater-treatment plant sludge in the Little Contentnea Creek subbasin, North Carolina.

23. Loads of $(A)$ total nitrogen and $(B)$ total phosphorus transported at 15 stations in calendar years 2000 and 2001 in relation to results from the Lizzie Research Station study, North Carolina.

24. Annual total nitrogen yield at selected stations in the Little Contentnea Creek subbasin, North Carolina.

25. Annual total phosphorus yield at selected stations in the Little Contentnea Creek subbasin, North Carolina.

26. Annual total nitrogen yield at selected stations in the Contentnea Creek subbasin, North Carolina.

27. Annual total phosphorus yield at selected stations in the Contentnea Creek subbasin, North Carolina

28. Annual total nitrogen yield at selected stations in the Neuse River basin, North Carolina ......... 40

29. Annual total phosphorus yield at selected stations in the Neuse River basin, North Carolina. ..... 41

30. Sources of total nitrogen, estimated by three different methods, delivered to the Neuse River estuary at New Bern, North Carolina

31. Sources of total phosphorus delivered to the Neuse River estuary at New Bern, North Carolina, in calendar year 2000 


\section{Tables}

1. Land use and basin characteristics for 14 sampling sites in the Neuse River drainage basin, North Carolina, 1999-2002

2. Soil type, streamflow characteristics, and nutrient data for 14 sampling sites in the Neuse River drainage basin, North Carolina, 1999-2002.

3. Screened intervals and median concentrations of selected chemical constituents in ground-water samples collected from aquifers and riparian zones at the Lizzie Research Station, North Carolina ....

4. Recharge dates and concentrations of dissolved gases and tritium in ground-water samples collected at the Lizzie Research Station, North Carolina. . ...

5. Seasonal and annual loads and annual yields of total nitrogen and phosphorus at 14 stations in the Neuse River basin, North Carolina.

6. Annual estimated background loads and yields for total nitrogen and total phosphorus for 14 stations in the Neuse River basin, North Carolina

\section{Appendix Tables}

1. Data available for stations included in the Lizzie Research Station study ..... 54

2. Ninety-five percent confidence intervals for annual loads and methods of load estimation used in the Lizzie Research Station study . ....

\section{Conversion Factors}

\begin{tabular}{lcl}
\hline Multiply & By & To obtain \\
\hline & Length & \\
\hline inch (in.) & 2.54 & centimeter $(\mathrm{cm})$ \\
foot $(\mathrm{ft})$ & 0.3048 & meter $(\mathrm{m})$ \\
mile $(\mathrm{mi})$ & 1.609 & kilometer $(\mathrm{km})$ \\
\hline \multicolumn{3}{c}{ Area } \\
\hline square mile $\left(\mathrm{mi}^{2}\right)$ & 2.590 & \\
\hline & Flow rate & \\
\hline foot per second $(\mathrm{ft} / \mathrm{s})$ & 0.3048 & meter per second $(\mathrm{m} / \mathrm{s})$ \\
cubic foot per second $\left(\mathrm{ft}^{3} / \mathrm{s}\right)$ & 0.02832 & cubic meter per second $\left(\mathrm{m}^{3} / \mathrm{s}\right)$ \\
\hline & Mass & \\
\hline ton, short $(2,000 \mathrm{lb})$ & 0.9072 & megagram $(\mathrm{Mg})$ \\
ton, long $(2,240 \mathrm{lb})$ & 1.016 & megagram $(\mathrm{Mg})$ \\
ton per year $($ ton/yr) & 0.9072 & megagram per year $(\mathrm{Mg} / \mathrm{yr})$ \\
ton per year $($ ton/yr) & 0.9072 & metric ton per year $(\mathrm{ton} / \mathrm{yr})$ \\
\hline & Radioactivity & \\
\hline picocurie per liter $(\mathrm{pCi} / \mathrm{L})$ & 0.037 & becquerel per liter $(\mathrm{Bq} / \mathrm{L})$ \\
\hline
\end{tabular}

Temperature in degrees Celsius $\left({ }^{\circ} \mathrm{C}\right)$ may be converted to degrees Fahrenheit $\left({ }^{\circ} \mathrm{F}\right)$ as follows:

$$
{ }^{\circ} \mathrm{F}=\left(1.8 \mathrm{x}^{\circ} \mathrm{C}\right)+32
$$




\section{Datum, Abbreviations, and Acronyms}

Vertical coordinate information is referenced to the National Geodetic Vertical Datum of 1929 (NGVD 29).

Horizontal coordinate information is referenced to the North American Datum of 1983 (NAD 83).

Altitude, as used in this report, refers to distance above the vertical datum.

Concentrations of chemical constituents in water are given either in milligrams per liter (mg/L) or micrograms per liter $(\mu \mathrm{g} / \mathrm{L})$.

\begin{tabular}{|c|c|}
\hline AMLE & Adjusted Maximum Likelihood Estimator \\
\hline ASW & air-saturated water \\
\hline ASWEA & air-saturated water with excess air \\
\hline $\mathrm{Ca}^{2+}$ & calcium \\
\hline CAFO & confined animal feeding operation \\
\hline CFC & chlorofluorocarbon \\
\hline CFC-11 & trichlorofluoromethane \\
\hline CFC-12 & dichlorodifluoromethane \\
\hline CFC-113 & trichlorotrifluoroethane \\
\hline $\mathrm{Cl}^{-}$ & chloride \\
\hline DIN & dissolved inorganic nitrogen \\
\hline DNRA & dissimilatory nitrate reduction to ammonium \\
\hline DO & dissolved oxygen \\
\hline DWO & Division of Water Quality \\
\hline ELI & eutrophication loading index \\
\hline $\mathrm{HCO}_{3}^{-}$ & bicarbonate \\
\hline ICP/MS & inductively coupled plasma and mass spectrometry \\
\hline LA & Linear Attribution \\
\hline LAD & Least Absolute Deviation \\
\hline Ibs/acre & pounds per acre \\
\hline$\mu \mathrm{m}$ & micrometer \\
\hline $\mathrm{mg} / \mathrm{sec}$ & milligram per second \\
\hline MIMS & multimedia integrated modeling system \\
\hline MLE & Maximum Likelihood Estimator \\
\hline $\mathrm{N}$ & nitrogen \\
\hline $\mathrm{N}_{2}$ & nitrogen gas \\
\hline NAWOA & National Water-Quality Assessment Program \\
\hline NCDENR & North Carolina Department of Environment and Natural Resources \\
\hline NCSU & North Carolina State University \\
\hline NERL & National Exposure Research Laboratory \\
\hline $\mathrm{NO}_{3}^{-}$ & nitrate \\
\hline NPDES & National Pollutant Discharge Elimination System \\
\hline$P$ & phosphorus \\
\hline $\mathrm{pg} / \mathrm{kg}$ & picogram per kilogram \\
\hline $\mathrm{SiO}_{2}$ & silica \\
\hline $\mathrm{SO}_{4}{ }^{2-}$ & sulfate \\
\hline SPARROW & spatially referenced regression on watershed model \\
\hline TEAP & terminal electron acceptor \\
\hline TMDL & total maximum daily load \\
\hline ton/mi ${ }^{2}$ & ton per square mile \\
\hline ton/mi²/yr & ton per square mile per year \\
\hline USEPA & U.S. Environmental Protection Agency \\
\hline USGS & U.S. Geological Survey \\
\hline WWTP & wastewater-treatment plant \\
\hline
\end{tabular}




\title{
Geochemistry and Characteristics of Nitrogen Transport at a Confined Animal Feeding Operation in a Coastal Plain Agricultural Watershed, and Implications for Nutrient Loading in the Neuse River Basin, North Carolina, 1999-2002
}

\author{
By T.B. Spruill ${ }^{1}$, A.J. Tesoriero ${ }^{1}$, H.E. Mew, Jr. $^{2}$, K.M. Farrell ${ }^{3}$, S.L. Harden ${ }^{1}$, A.B. Colosimo ${ }^{4}$, and S.R. Kraemer ${ }^{5}$
}

\section{Abstract}

Chemical, geologic, hydrologic, and age-dating information collected between 1999 and 2002 were used to examine the transport of contaminants, primarily nitrogen, in ground water and the pathways to surface water in a coastal plain setting in North Carolina. Data were collected from more than 35 wells and 4 surface-water sampling sites located in a 0.59 square-mile basin to examine detailed hydrogeology and geochemical processes affecting nutrient fate and transport. Two additional surface-water sampling sites were located downstream from the primary study site to evaluate basin-scale effects. Chemical and flow data also were collected at an additional 10 sites in the Coastal Plain portion of the Neuse River basin located between Kinston and New Bern, North Carolina, to evaluate loads transported in the Neuse River and primary tributary basins.

At the Lizzie Research Station study site in North Carolina, horizontal flow is induced by the presence of a confining unit at shallow depth. Age-dating, chemical, and piezometric data indicate that horizontal flow from the surficial aquifer is the dominant source of ground water to streamflow. Nitrogen applied on cultivated fields at the Lizzie Research Station is substantially reduced as it moves from recharge to discharge areas. Denitrification in deeper parts of the aquifer and in riparian zones is indicated by a characterization of redox conditions in the aquifer and by the presence of excess nitrogen gas. Direct ground-water discharge of nitrate to surface water during base-flow conditions is unlikely to be significant because of strongly reducing conditions that occur in the riparian zones of these streams. Nitrate loads from a drainage tile at the study site may account for much of the nitrate load in the receiving stream, indicating that a major source of nutrients from ground water to this stream is artificial drainage. During base-flow conditions when the streams are not flowing, it is hypothesized that the mineralization of organic matter on the streambed is the source of nitrate and(or) ammonium in the stream. Base flow is a small contributor to nitrogen loads, because both flows and inorganic nitrogen concentrations are low during summer months.

Effects of a confined hog operation on ground-water quality also were evaluated. The use of sprayed swine wastes to fertilize crops at the Lizzie Research Station study site since 1995 resulted in increased concentrations of nitrate and other chemical constituents in ground water beneath spray fields when compared to ground water beneath fields treated with commercial fertilizer. The nitrate concentration in ground water from the spray field well increased by a factor of 3.5 after 4 years of spray applications. Nitrate concentrations ranged from

\footnotetext{
${ }^{1}$ U.S. Geological Survey, Raleigh, North Carolina.

${ }^{2}$ North Carolina Department of Environment and Natural Resources, Division of Water Quality, Raleigh, North Carolina.

${ }^{3}$ North Carolina Geological Survey, Division of Land Resources, Raleigh, North Carolina.

${ }^{4}$ Monroe Community College, Department of Chemistry and Geosciences, Rochester, New York.

${ }^{5}$ U.S. Environmental Protection Agency, National Exposure Research Laboratory/Office of Research and Development, Athens, Georgia.
} 


\section{Nitrogen Transport at a Confined Animal Feeding Operation in an Agricultural Watershed in the Neuse River Basin, 1999-2002}

10 to 35 milligrams per liter, and one concentration as high as 56 milligrams per liter was observed in water from this well in spring 2002. This finding is in agreement with findings of other studies conducted in the Coastal Plain of North Carolina that nitrate concentrations were significantly higher in ground water from cultivated fields sprayed with swine wastes than from fields treated with commercial fertilizer.

Loads and yields of nitrogen and phosphorus in 14 streams in the Neuse River basin were evaluated for calendar years 2000 and 2001. Data indicate that anthropogenic effects on nitrogen yields were greatest in the first-order stream studied (yields were greater than 2 tons per square mile [ton $/ \mathrm{mi}^{2}$ ] and $1 \mathrm{ton} / \mathrm{mi}^{2}$ or less in second- and higher-order streams) in the Little Contentnea Creek subbasin. Nitrogen yields in streams in the Contentnea Creek subbasin ranged from 0.59 to 2 ton $/ \mathrm{mi}^{2}$ with typical yields of approximately $1 \mathrm{ton} / \mathrm{mi}^{2}$. Contentnea Creek near Evansdale had the highest yield ( 2 ton $/ \mathrm{mi}^{2}$ ), indicating that a major source of nitrogen is upstream from this station. Nitrogen yields were lower at Contentnea Creek at Hookerton in 2000 and 2001 compared to previous yield estimates based on 1990 data. Along the main stem of the Neuse River, nitrogen yields during 2000 and 2001 ranged from 3.4 ton $/ \mathrm{mi}^{2}$ in Bear Creek, a tributary west of Kinston, North Carolina, to 0.55 ton $/ \mathrm{mi}^{2}$ in the Trent River. The total nitrogen load delivered to the Neuse estuary in 2000 was 4,807 tons or 9.61 million pounds, and the total phosphorus load was 425 tons or 850,000 pounds. It is estimated that about 17 percent of the delivered total nitrogen load is from background sources-35 percent from point sources and 48 percent from nonpoint sources.

Annual phosphorus yields in the Little Contentnea Creek subbasin for 2000 and 2001 ranged from 0.02 to about $0.15 \mathrm{ton} / \mathrm{mi}^{2}$. In contrast with total nitrogen yields, the larger total phosphorus yields were in higher-order streams (about three times greater), indicating either that the major source of phosphorus in the Little Contentnea Creek subbasin originates in the larger streams or the phosphorus is deposited by sediment eroded from low-order headwater streams and deposited on the bed. Phosphorus yields in the Contentnea Creek subbasin ranged from 0.02 to $0.15 \mathrm{ton} / \mathrm{mi}^{2}$. Phosphorus yields for Contentnea Creek at Hookerton were about 5 to 6 times the expected background yield, although yields for phosphorus reported for 2000 and 2001 for Contentnea Creek at Hookerton were considerably lower than those reported for 1990.

Phosphorus yields in the Neuse River basin ranged from 0.02 to $0.29 \mathrm{ton} / \mathrm{mi}^{2}$, with the highest yields occurring near New Bern in the vicinity of the upper Neuse estuary.

The total phosphorus load transported to the Neuse estuary in 2000 was 425 tons. No recently published information was found on total point-source contributions of phosphorus to the Neuse River near Fort Barnwell for this study; therefore, general estimates from past studies were used. Based on this analysis, about 7 percent of the total phosphorus load in 2000 was from background sources, about 41 percent was from anthropogenic point sources, and 52 percent was from anthropogenic nonpoint sources.
Effects of cultural eutrophication with respect to phosphorus enrichment in coastal plain streams of the Neuse River basin are much greater than for nitrogen. The eutrophication loading index of phosphorus ranged between 2 and 12 times, and values typically were 5 to 6 times the estimated background yield for second- and higher-order streams. The eutrophication loading index of total nitrogen ranged between 1 and 5 times, and values typically were about 2 times the estimated background yield.

\section{Introduction}

Eutrophication has been identified as a primary problem in the Albemarle-Pamlico estuaries, and excess algal growth and fish kills in the estuaries have been attributed to the occurrence of excess nitrogen. Worldwide, nitrate is recognized as the most ubiquitous contaminant of ground water (Spaulding and Exner, 1993) and in agriculture as the most extensive source of nitrate to ground and surface water (Hallberg, 1989). According to the Clean Water Action Plan (U.S. Environmental Protection Agency and U.S. Department of Agriculture, 1998), overenrichment by nutrients is the largest overall source of impairment in the Nation's rivers and streams. In the southeastern United States, streams and receiving waters have been adversely affected by eutrophication (Pinckney and others, 1997), increased hypoxia (Paerl and others, 1998), fish kills (Burkholder and others, 1995), and outbreaks of toxic species (Burkholder and Glasgow, 1997). In general many researchers agree that excessive nutrient loading to the Neuse River and estuary, particularly nitrogen, has been the primary contributing factor for fish kills and algal blooms in the Neuse estuary (Stow and Borsuk, 2003).

Within North Carolina's Neuse River basin, nonpointsource nutrient loads have been identified as a major component of increased estuarine nutrient loading (Spruill and others, 1998; Stow and Borsuk, 2003). In particular, confined animal feeding operations (CAFOs), which have increased five-fold over the past two decades in the North Carolina Coastal Plain (Mallin, 2000), appear to have a substantial effect on nitrogen and phosphorus loading to streams (Glasgow and Burkholder, 2000). The predominant wastewater-treatment system used in CAFOs is lagoons and spray fields, in which waste is flushed from confined animal housing into large earthen lagoons and then periodically sprayed onto agricultural fields in accordance with State regulations. Reactive nitrogen in the sprayed wastewater does one or more of the following: volatilizes into the atmosphere, becomes assimilated by crops, runs off into adjacent streams, or infiltrates into the ground-water system and eventually discharges to streams. Although more than 70 percent of the streamflow in the Coastal Plain may be derived from ground water (McMahon and Lloyd, 1995), the fate and transport of nitrate $\left(\mathrm{NO}_{3}{ }^{-}\right)$from these CAFOs, as it moves from field to stream through the ground-water system, has not previously been assessed in North Carolina. 
The National Exposure Research Laboratory (NERL) of the U.S. Environmental Protection Agency's (USEPA) Office of Research and Development began a project in 1998 to develop a multimedia integrated modeling system (MIMS). The system is intended to represent the transport and fate of nutrients and chemical stressors over multiple scales and through air, ground water, and surface water. MIMS is intended to improve the environmental management community's ability to evaluate the effects of air quality and watershed management practices on streams and estuarine conditions. The USEPA recognized the importance of a multimedia data set for developing and testing the modeling system.

The MIMS project was developed with two parallel objectives: (1) to methodically account, through scientific study, for the advective transport of stressors, such as nutrients, through the atmospheric-hydrospheric system; and (2) to develop integrated multimedia software to model the transformation of these nutrients as they move through multiple environmental media. The U.S. Geological Survey (USGS) and the North Carolina Department of Environment and Natural Resources (NCDENR) were involved in the first of these objectives, primarily by providing data adequate to test the results of the developed models. The general developmental approach of the USEPA MIMS effort was presented in Johnston and others (2000).

A thorough understanding of environmental processes, ranging from local to watershed scales, is necessary to develop accurate predictive environmental models. This concept of a multiple-scale study forms the basis for understanding environmental processes taking place within a watershed and is an integral part of the USGS National Water-Quality

Assessment (NAWQA) Program. With a multiple-scale study in mind, the Neuse River basin was selected for study because of poor water-quality conditions observed in the Neuse River estuary and Pamlico Sound due to excess nutrients (North Carolina Department of Environment and Natural Resources, 1999). The USGS, NCDENR, and USEPA NERL

cooperatively worked together to provide information on movement of a contaminant from a (1) source (atmosphere, plants, fertilizer, animal manure, and(or) other sources) near land surface, through the (2) unsaturated zone to the water table, and then from the (3) recharge area laterally and vertically through the aquifer in the saturated zone into (4) natural streams (through the hyporheic zone and into the stream channel) or artificial channels (through drainage tiles or ditches).

The USGS and NCDENR Division of Water Quality, Groundwater Section, began data-collection activities in March 1999 to provide hydrogeologic and water-quality information on transport and fate of nitrogen in a small watershed, the Lizzie Research Station (fig. 1), in the Little Contentnea Creek subbasin. In addition, the effects of swine-waste application as fertilizer on ground-water quality were evaluated by comparing water-quality characteristics in wells sampled at the Lizzie Research Station by the USGS as part of the NAWQA Program in 1995 prior to the application of swine wastes to the fields. In 2000, water-quality data collection began at 12 additional surface-water sites to evaluate surface-water loading characteristics in the Contentnea Creek subbasin and the Neuse River basin. The Contentnea Creek subbasin was selected because of the large nitrogen and phosphorus loads contributed to the Neuse River-as much as 45 percent of the phosphorus load and 35 percent of the nitrogen load delivered to the Neuse estuary (Spruill and others, 1996). All sites were sampled for 18-24 months to estimate loads of nitrogen and phosphorus. Data collected as part of the RiverNet Program at North Carolina State University also were used to evaluate the adequacy of techniques used to calculate annual stream loads (North Carolina State University, 2004).

This report summarizes activities of the USGS for the MIMS project between 1999 and 2002, including data collected during the study and general findings regarding geology, hydrology, and the fate and transport of nitrogen in ground water and streams. This information is presented for watersheds ranging in size from 0.59 square mile $\left(\mathrm{mi}^{2}\right)$ at Plum Tree Branch (site S2, fig. 2; tables 1, 2) to about $153 \mathrm{mi}^{2}$ at Little Contentnea Creek near Willow Green (site S6, fig. 1; tables 1, 2) to characterize processes occurring in smaller coastal plain watersheds. In addition, information is provided for larger-scale stream systems, including the Neuse River estuary near New Bern (fig. 1), which drains more than $4,000 \mathrm{mi}^{2}$, to evaluate implications that these processes may have on nitrogen and phosphorus transport in the Neuse River. Some of the data presented herein were obtained from USGS NAWQA studies (Spruill and others, 1998) and from another cooperative project between NCDENR and the USEPA directed at evaluating the effects of artificial drains on surface-water quality (Harden and Spruill, 2004).

\section{Description of the Study Area}

The Lizzie Research Station study site is located southeast of Farmville in Greene County, in the North Carolina Coastal Plain (fig. 1), south of the confluence of Sandy Run and Middle Swamp (fig. 2). The site has been under study by the NCDENR since 1993. Most of the Lizzie Research Station study site is drained by a first-order stream (for a definition of stream orders, see Strahler, 1963), known locally as Plum Tree Branch (fig. 2), which is a tributary to Sandy Run and drains $0.59 \mathrm{mi}^{2}$. Land use in the area primarily is agricultural, with row crops typically of corn, wheat, and soybeans.

Farming practices at the Lizzie Research Station changed during the mid-1990's. Prior to 1995, crops were fertilized by using inorganic ammonium nitrate applied at the suggested agronomic rate for corn (about 150-200 pounds per acre (lbs/acre), North Carolina State University, 1992). After 1995, crops were fertilized with sprayed swine-waste lagoon effluent. Construction of five hog houses and a lagoon began in 1994, 


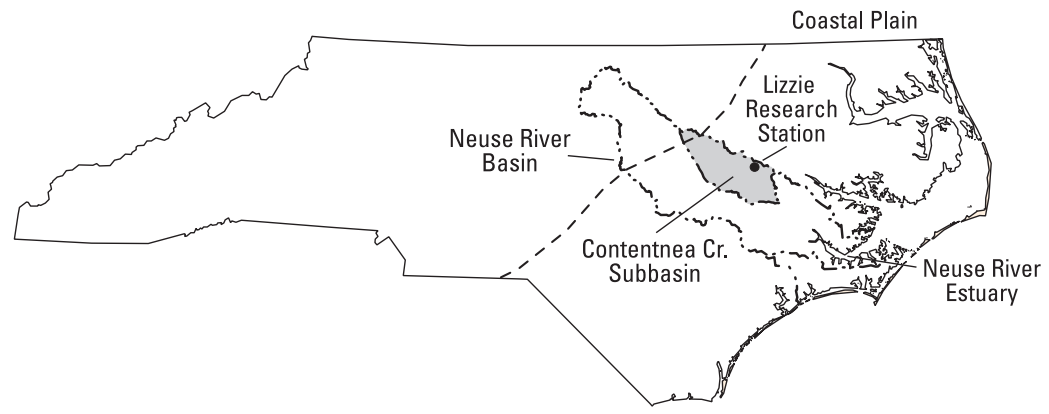

LOCATION OF LIZZIE RESEARCH STATION, CONTENTNEA CREEK SUBBASIN, AND NEUSE ESTUARY AND RIVER BASIN IN THE COASTAL PLAIN PHYSIOGRAPHIC PROVINCE OF NORTH CAROLINA

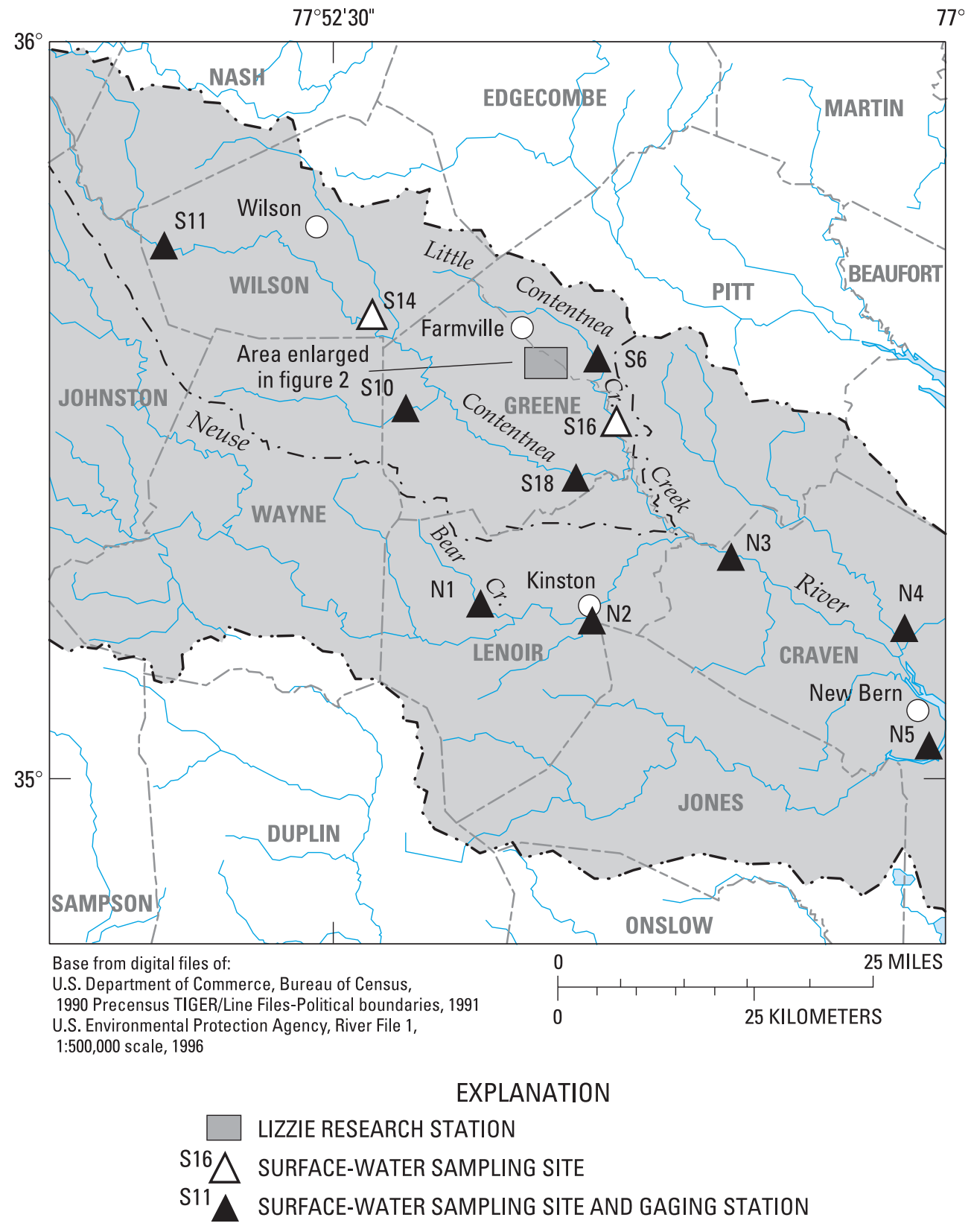

Figure 1. Locations of Lizzie Research Station and multimedia integrated modeling system (MIMS) sampling sites in the Neuse River basin, North Carolina. 


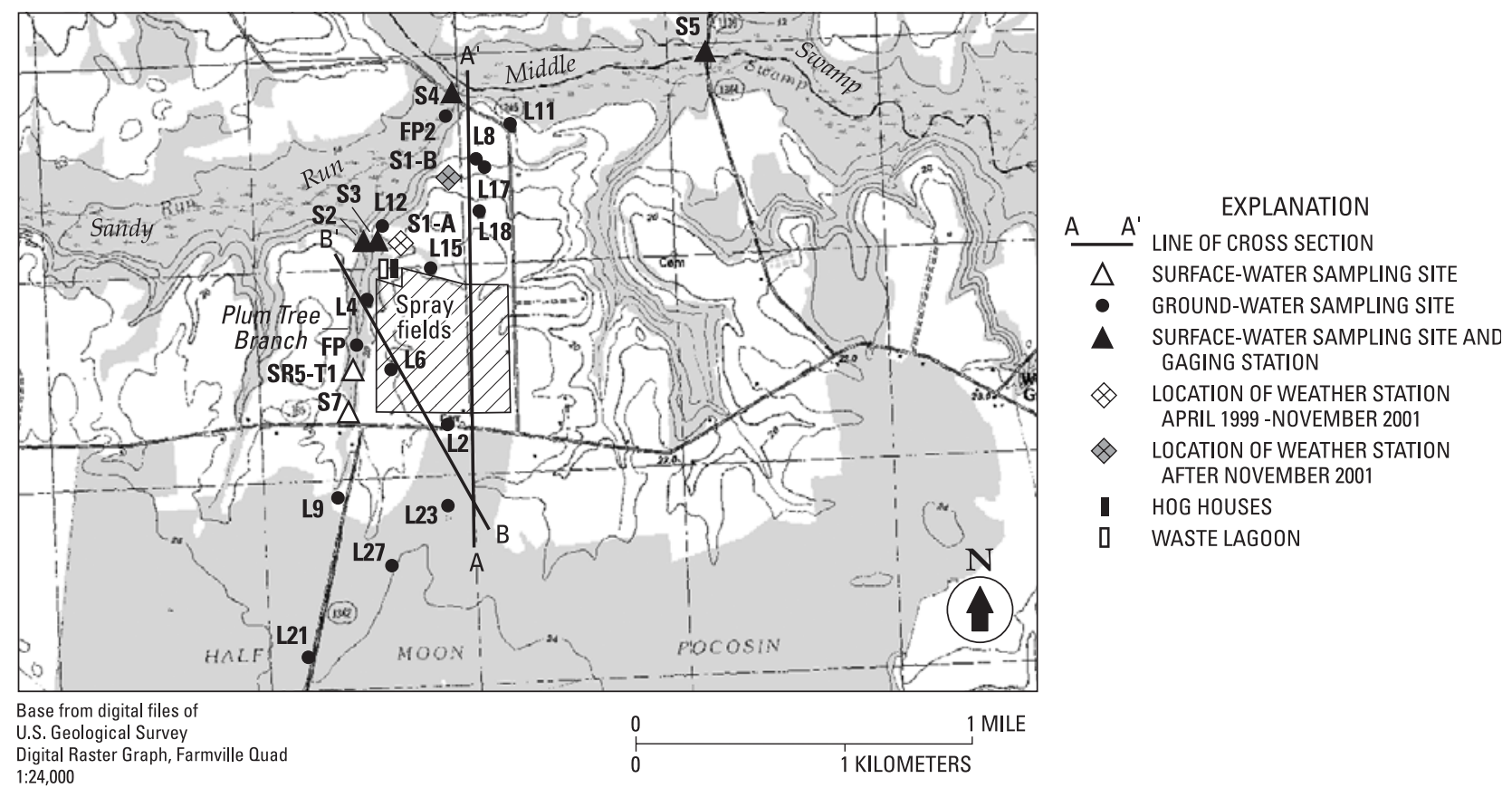

Figure 2. Locations of surface-water and ground-water sampling sites at the Lizzie Research Station, North Carolina.

Table 1. Land use and basin characteristics for 14 sampling sites in the Neuse River drainage basin, North Carolina, $1999-2002$.

[NPDES, National Pollutant Discharge Elimination System; $\mathrm{mi}^{2}$, square mile]

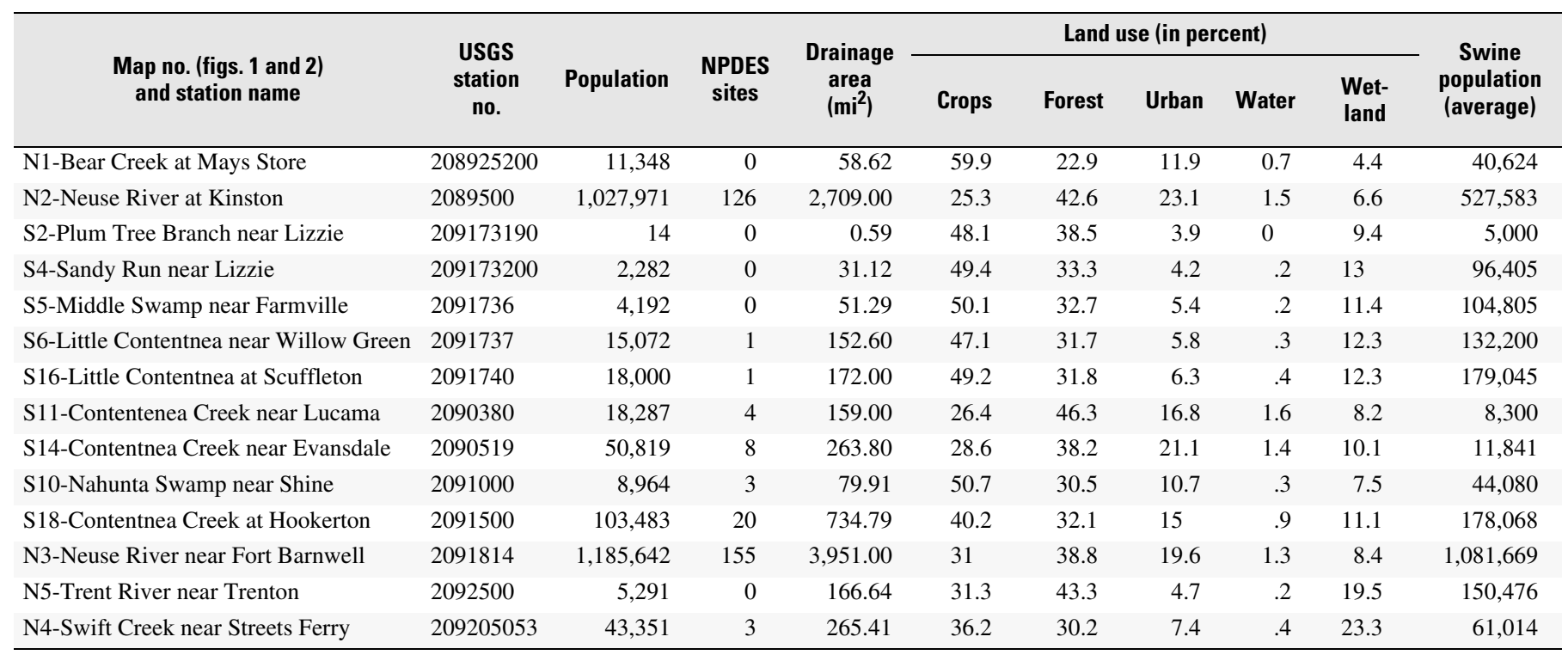


Table 2. Soil type, streamflow characteristics, and nutrient data for 14 sampling sites in the Neuse River drainage basin, North Carolina, $1999-2002$. [in., inch; $\mathrm{mg} / \mathrm{L}$, milligram per liter; $\mathrm{ft}^{3} / \mathrm{s}$, cubic foot per second]

\begin{tabular}{|c|c|c|c|c|c|c|c|}
\hline $\begin{array}{l}\text { Map no. (figs. } 1 \text { and 2) } \\
\text { and station name }\end{array}$ & $\begin{array}{c}\text { Percent } \\
\text { A/B soils }{ }^{\mathrm{a}}\end{array}$ & $\begin{array}{l}\text { Percent } \\
\text { C/D soils }\end{array}$ & $\begin{array}{l}\text { Average } \\
\text { slope }\end{array}$ & $\begin{array}{l}\text { Base-flow index } \\
\text { (annual base flow } \\
\text { [in.]/ annual total } \\
\text { flow [in.]) }\end{array}$ & $\begin{array}{l}\text { Median total nitrogen } \\
\text { ([mg/L] / range } \\
\text { [mg/L]/ number of } \\
\text { observations) }\end{array}$ & $\begin{array}{c}\text { Median total phosphorus } \\
\text { ([mg/L]/ range } \\
\text { [mg/L]/ number of } \\
\text { observations) }\end{array}$ & $\begin{array}{c}\text { Median flow / range } \\
\text { of flow } \\
\left(\mathrm{ft}^{3} / \mathbf{s}\right)\end{array}$ \\
\hline N1-Bear Creek at Mays Store & 54.5 & 45.5 & 0.9068 & 68.1 & $3.1 / 2.2-4.6 / 23$ & $0.1 / 0.04-0.66 / 23$ & $37 / 8.4-8,000$ \\
\hline N2-Neuse River at Kinston & 57.2 & 42.8 & 2.6518 & 64.8 & $0.56 / 0.51-1 / 48$ & $0.12 / 0.057-0.195 / 49$ & $1,320 / 260-35,800$ \\
\hline S2-Plum Tree Branch near Lizzie & 34.2 & 65.8 & .7192 & 51.8 & $6.5 / 1.6-13 / 27$ & $0.08 / 0.03-0.86 / 27$ & $0.09 / 0.04-17.5$ \\
\hline S4-Sandy Run near Lizzie & 38.3 & 61.7 & .6714 & 53.4 & $1.4 / 0.15-2.3 / 29$ & $0.34 / 0.11-0.81 / 33$ & $2.2 / 0.03-1,760$ \\
\hline S5-Middle Swamp near Farmville & 35.9 & 64.1 & .6584 & 51.2 & $0.97 / 0.51-1.4 / 22$ & $0.33 / 0.11-1.08 / 31$ & $7.4 / 0.01-1,410$ \\
\hline S6-Little Contentnea near Willow Green & 34.9 & 65.2 & .7383 & 53.9 & $0.98 / 0.63-1.4 / 25$ & $0.27 / 0.08-0.60 / 31$ & $30 / 1.1-3,160$ \\
\hline S16-Little Contentnea at Scuffleton & 59.1 & 40.9 & .7689 & 61.5 & $0.9 / 0.59-1.3 / 20$ & $0.19 / 0.08-0.53 / 23$ & $66 / 20-4,975$ \\
\hline S11-Contentenea Creek near Lucama & 60.5 & 38.9 & 2.3193 & 53.9 & $0.82 / 0.01-0.97 / 20$ & $0.037 / 0.02-0.07 / 20$ & $68 / 7.9-2,270$ \\
\hline S14-Contentnea Creek near Evansdale & 56.9 & 42.7 & 1.9495 & 76.4 & $1.3 / 0.05-2.73 / 20$ & $0.11 / 0.04-0.38 / 20$ & $172 / 6.5-11,308$ \\
\hline S10-Nahunta Swamp near Shine & 51.4 & 48.5 & 1.1623 & 64.6 & $1.4 / 0.91-2.1 / 21$ & $0.08 / 0.02-0.17 / 20$ & $51 / 1-1,870$ \\
\hline S18-Contentnea Creek at Hookerton & 53.4 & 46.4 & 1.467 & 70.9 & $1.2 / 0.86-1.9 / 72$ & $0.138 / 0.019-0.255 / 72$ & $480 / 18-31,500$ \\
\hline N3-Neuse River near Fort Barnwell & 54.2 & 45.7 & 2.1958 & 71.8 & $1.1 / 0.66-1.6 / 21$ & $0.11 / 0.03-0.166 / 21$ & $2,000 / 254-40,300$ \\
\hline N5-Trent River near Trenton & 35.6 & 64.4 & .7276 & 53 & $0.94 / 0.42-4.6 / 95^{\mathrm{c}}$ & $0.01 / 0.09-0.83 / 95^{\mathrm{c}}$ & $67 / 0.84-12,000$ \\
\hline N4-Swift Creek near Streets Ferry & 14.1 & 85.8 & .6118 & 20.5 & $0.5 / 0.2-2.5 / 147^{\mathrm{c}}$ & $0.13 / 0.04-1.3 / 147^{\mathrm{c}}$ & $133 / 1-5,040$ \\
\hline
\end{tabular}

${ }^{\mathrm{a}}$ Dual hydrologic soil groups: A-(Low runoff potential). The soils have a high infiltration rate even when thoroughly wetted. They chiefly consist of deep, well drained to excessively drained sands or gravels. They have a high rate of water transmission. B-The soils have a moderate infiltration rate when thoroughly wetted. They chiefly are moderately deep to deep, moderately well drained to well drained soils that have moderately fine to moderately coarse textures. They have a moderate rate of water transmission (U.S. Department of Agriculture, 2002).

${ }^{b}$ Dual hydrologic soil groups: C-The soils have a slow infiltration rate when thoroughly wetted. They chiefly have a layer that impedes downward movement of water or have moderately fine to fine texture. They have a slow rate of water transmission. D-(High runoff potential). The soils have a very slow infiltration rate when thoroughly wetted. They chiefly consist of clay soils that have a high swelling potential, soils that have a permanent high water table, soils that have a claypan or clay layer at or near the surface, and shallow soils over nearly impervious material. They have a very slow rate of water transmission (U.S. Department of Agriculture, 2002).

${ }^{\mathrm{c}}$ Data collected by the North Carolina Department of Environment and Natural Resources. 
and in late 1995, a confined animal feeding operation with approximately 5,000 animals began in the central part of the study area (fig. 2). A lagoon was constructed on the site to hold waste drained from the five hog houses. Liquid from the lagoon provided the primary source of nitrogen sprayed onto about 90 acres of fields (with about 70 acres inside the Plum Tree Branch watershed) in the northwestern portion of the Lizzie Research site (fig. 2). All property within the Lizzie study site is privately owned.

In addition to gaining an understanding of surface- and ground-water relations at the Lizzie Research site, a major objective of the MIMS study was to determine nutrient loading and discharge characteristics in drainages of the Neuse River basin. Seventeen stream sites (figs. 1,2) were sampled and streamflow was measured to characterize flow and nutrient loads or to investigate short-term transport processes and behavior (sites S3, S7, and SR5-T1, fig. 2). The natural streams studied range in drainage area from about $0.59 \mathrm{mi}^{2}$ at Plum Tree Branch to almost 4,000 $\mathrm{mi}^{2}$ at the Neuse River near Fort Barnwell (table 1). A small tile-drain site, SR5-T1 (fig. 2), drains an area of about $0.01 \mathrm{mi}^{2}$ into Plum Tree Branch. A weather station was established at this site and near one of the surface-water gages to evaluate atmospheric inputs of nitrogen into the basin. General land use, soil, and drainage-basin characteristics in the study area are presented in tables 1 and 2.

Hydrologic conditions in the Neuse River basin between 1999 and 2002 were highly variable. At the most downstream station, the Neuse River near Fort Barnwell (site N3, fig. 1), the highest daily flow of 57,000 cubic feet per second $\left(\mathrm{ft}^{3} / \mathrm{s}\right)$ occurred on September 20, 1999 (Ragland and others, 2003) during Hurricane Floyd, whereas the lowest daily mean of $340 \mathrm{ft}^{3} / \mathrm{s}$ occurred on June 27, 2002 (Ragland and others, 2003). The years for which complete data were collected for the current study include calendar years 2000 and 2001. The average daily flow of $3,679 \mathrm{ft}^{3} / \mathrm{s}$ in calendar year 2000 was closer to the long-term average daily flow of $4,217 \mathrm{ft}^{3} / \mathrm{s}$ (1997-2004) than in calendar year $2001\left(2,464 \mathrm{ft}^{3} / \mathrm{s}\right)$.

\section{Methods}

Methods used for conducting the study are presented in the following sections. Information on basic well construction and location, surface-water site locations, sample-collection procedures for surface-water and ground-water sampling, laboratory analytical procedures, and statistical methods used for analysis of load data are included.

\section{Ground-Water Sampling Sites}

The NCDENR Division of Water Quality (DWQ), Groundwater Section, installed 27 wells at 12 sites in the basin
(Ted Mew, North Carolina Department of Environment and Natural Resources, Division of Water Quality, written commun., 2000) beginning in 1993. In 2000, eight new wells were installed on the site. The locations of wells at the Lizzie Research site are shown in figure 2, and screen-interval information for each of the wells is presented in table 3 . The DWQ Drilling Unit constructed all wells in the study area according to general procedures established for monitoringwell construction by the State of North Carolina.

\section{Surface-Water Sampling Sites and Weather Station}

In order to evaluate interactions of ground water with surface water in the study area and to characterize hydrology and chemical quality of water draining the site, six primary streamgaging sites were established (fig. 2). Three streamgages were installed in 1999 at the Lizzie Research site - a gage on Sandy Run (S4, fig. 2), a weir and gage on a small first-order tributary (S2, fig. 2) on the west side of the study area, and a weir and recorder on a drainage ditch near the center of the study site (S3, fig. 2). An ungaged sampling site upstream from the S2 gage (S7, fig. 2) was selected as a supplementary sampling site to evaluate the chemical quality of water in areas upstream from the hog-farm operation. Two more gages, one at Middle Swamp near Farmville (S5, fig. 2) and one at Little Contentnea Creek near Willow Green (S6, fig. 1) were installed to evaluate basin-scale effects on water chemistry and nutrient loading.

In addition to the six primary sampling sites, several sites, including Contentnea Creek at Hookerton (S18), Nahunta Swamp near Shine (S10), Contentnea Creek near Lucama (S11), Contentnea Creek near Evansdale (S14), Bear Creek at Mays Store (N1), Neuse River at Kinston (N2), and Neuse River near Fort Barnwell (N3, fig. 1), were sampled to characterize seasonal nutrient concentrations and loading from streams in the Contentnea Creek basin down to the downstream-most station at Fort Barnwell, N.C. Flow data from two additional stations in tributaries to the Neuse River-Trent River near Trenton (N5, fig. 1) and Swift Creek at Streets Ferry (N4, fig. 1)-also were included. Water-quality data collected by the DWQ for the Trent River and Swift Creek were used in conjunction with USGS streamflow data in order to calculate nutrient loads to the Neuse River estuary. A weather station with a recorder (fig. 3) also was established initially at one location (S1-A, fig. 2) and later moved to a more suitable location about 1,000 feet (ft) away (S1-B, fig. 2). Measured properties include temperature, humidity, solar radiation, wind speed, wind direction, and soil moisture at $0.16,0.32$, and $0.98 \mathrm{ft}$ below land surface. 


\section{Nitrogen Transport at a Confined Animal Feeding Operation in an Agricultural Watershed in the Neuse River Basin, 1999-2002}

Table 3. Screened intervals and median concentrations of selected chemical constituents in ground-water samples collected from aquifers and riparian zones at the Lizzie Research Station, North Carolina.

[NGVD 29, National Geodetic Vertical Datum of 1929; mg/L, milligram per liter; N, nitrogen; <, less than; —, no data. Units are milligrams per liter unless otherwise noted. Most samples were collected from March 1999 to June 2002]

\begin{tabular}{|c|c|c|c|c|c|c|c|c|}
\hline \multirow[t]{2}{*}{ Well name } & \multirow{2}{*}{$\begin{array}{l}\text { Well name and } \\
\text { location shown in } \\
\text { figure } 2 \text { (several wells } \\
\text { may be colocated) }\end{array}$} & \multicolumn{2}{|c|}{$\begin{array}{c}\text { Screened interval } \\
\text { (feet above NGVD 29) }\end{array}$} & \multirow{2}{*}{$\begin{array}{l}\text { Dissolved } \\
\text { oxygen } \\
\text { (mg/L) }\end{array}$} & \multirow{2}{*}{$\underset{\text { (units) }}{\mathrm{pH}}$} & \multirow{2}{*}{$\underset{(\mathbf{m g} / \mathbf{L})}{\text { Calcium }}$} & \multirow{2}{*}{$\underset{(\mathrm{mg} / \mathrm{L})}{\text { Magnesium }}$} & \multirow{2}{*}{$\begin{array}{l}\text { Potassium } \\
\text { (mg/L) }\end{array}$} \\
\hline & & Bottom & Top & & & & & \\
\hline \multicolumn{9}{|c|}{ Surficial aquifer (unconfined) } \\
\hline $\mathrm{L} 2$ & L2 & 61.0 & 70.9 & 3.4 & 4.6 & 3.5 & 3.6 & .7 \\
\hline L2S & $\mathrm{L} 2$ & 72.5 & 75.5 & 4.2 & 5.1 & 2.2 & 2.5 & .7 \\
\hline L2D & L2 & 57.4 & 59.4 & 6 & 5.2 & 6.0 & 1.1 & 3.9 \\
\hline L3 & L2 & 39.0 & 54.1 & .4 & 5.1 & 2.4 & .4 & 2.0 \\
\hline $\mathrm{L} 4$ & L4 & 54.5 & 59.4 & 5.5 & 5.3 & 27 & 4.6 & 5.2 \\
\hline L4S & L4 & 56.4 & 59.4 & 4.2 & 4.2 & 28 & 7.1 & 9.1 \\
\hline L4D & L4 & 52.5 & 54.5 & 3.1 & 5.0 & 35 & 5.4 & 7.0 \\
\hline L5 & L6 & 44.3 & 54.1 & .1 & 4.4 & 3.5 & .6 & 1.5 \\
\hline L6 & L6 & 66.3 & 69.6 & 2.8 & 4.3 & 41 & 15 & 9.2 \\
\hline L6S & L6 & 70.5 & 72.5 & 1.0 & 4.7 & 41 & 14 & 13 \\
\hline L6D & L6 & 55.4 & 57.4 & .3 & 4.5 & 1.9 & .7 & 1.9 \\
\hline L9 & L9 & 52.8 & 62.7 & .2 & 6.0 & 38 & 2.5 & 1.7 \\
\hline L15 & L15 & 52.8 & 63.0 & 1.7 & 4.1 & 15 & 7.6 & 2.4 \\
\hline L15D & L15 & 50.5 & 52.5 & 1.1 & 5.9 & 25 & 3.7 & 1.5 \\
\hline L18D & L18 & 46.6 & 48.6 & 1.9 & 5.3 & 13 & .9 & 1.4 \\
\hline L20 & L21 & 59.4 & 69.2 & .1 & 4.9 & 3.3 & .3 & .5 \\
\hline L23 & L23 & 68.9 & 73.8 & 2.1 & 5.3 & 3.6 & .1 & .2 \\
\hline L24 & L23 & 53.8 & 58.7 & .5 & 7 & 88 & 1.8 & .9 \\
\hline L27 & L27 & 59.7 & 69.6 & 4.5 & 5.0 & .8 & .2 & .1 \\
\hline \multicolumn{9}{|c|}{ Alluvial aquifer (unconfined) } \\
\hline L7 & L8 & 20.7 & 40.7 & 7.8 & 4.7 & 13 & 7.4 & 4.5 \\
\hline L8S & L8 & 40.7 & 45.9 & 6.7 & 4.3 & 12 & 6.2 & 4.4 \\
\hline L8D & L8 & 25.9 & 27.9 & 1.8 & 4.7 & 15 & 6.6 & 4.3 \\
\hline L11S & L11 & 40.0 & 44.9 & 3.4 & 5.1 & 9.1 & 2.2 & 5.0 \\
\hline L11D & L11 & 24.6 & 26.6 & 4.3 & 4.5 & 16 & 5.7 & 7.1 \\
\hline L11 & L11 & 31.8 & 41.7 & 3.2 & 5.0 & 7.9 & 2.3 & 4.6 \\
\hline \multicolumn{9}{|c|}{ Yorktown aquifer (confined and unconfined) } \\
\hline L10 & L11 & 2.3 & 17.1 & 0.2 & 6.2 & 32 & 1.4 & 1.6 \\
\hline L12 & L12 & 8.5 & 28.5 & .1 & 7.5 & 59.0 & 2.2 & 2.0 \\
\hline L14 & L15 & 18.0 & 28.2 & .1 & 7.45 & 51.9 & 2.0 & 1.1 \\
\hline L16 & L4 & 14.1 & 29.2 & .4 & 7.4 & 60.5 & 1.7 & 2.2 \\
\hline L17 & L18 & 11.5 & 31.5 & .1 & 7.4 & 55.0 & 1.8 & 1.7 \\
\hline L19 & L21 & 12.1 & 37.4 & .1 & 7.5 & 61.1 & 1.4 & 1.4 \\
\hline L22 & L22 & 17.7 & 37.7 & .1 & 7.3 & 66 & 1.4 & 1.1 \\
\hline L26 & L27 & 7.9 & 27.9 & 6 & 7.5 & 52.5 & 1.2 & 1.3 \\
\hline \multicolumn{9}{|c|}{ Peedee Formation (confined) } \\
\hline $\mathrm{L} 25$ & L23 & -33.5 & -25.9 & 0.1 & 7.3 & 61.2 & 2.4 & 2.2 \\
\hline L55 & $\mathrm{L} 2$ & 7.2 & 27.6 & .1 & 7.2 & 35.1 & 1.3 & 1.9 \\
\hline \multicolumn{9}{|c|}{ Streambed and riparian zone } \\
\hline Streambed-center (GR089) & Drainage ditch at S3 & 2.0 & 1.6 & 0.1 & 5.2 & 8.2 & 2.3 & 2.9 \\
\hline $\begin{array}{l}\text { Riparian/upland boundary } \\
\text { (GR157) }\end{array}$ & FP & 5.2 & 4.9 & .3 & 4.5 & 7.2 & 5.5 & 4.0 \\
\hline Streambed-center (GR155) & Plum Tree near FP & 2.0 & 1.6 & .3 & 5.5 & 15 & 2.7 & 4.0 \\
\hline Streambank-right (GR156) & Plum Tree near FP & 2.6 & 2.3 & .2 & 5.3 & 9.8 & 3.1 & 7.9 \\
\hline Streambed-center (GR149) & Plum Tree at S2 & 2.0 & 1.6 & .3 & 5.0 & 5.4 & 1.1 & 1.7 \\
\hline Streambed-center (GR148) & Plum Tree at S2 & 4.3 & 3.9 & 1.1 & 5.1 & 6.0 & 1.1 & 1.2 \\
\hline Streambed-center (GR152) & Sandy Run at S4 & 2.6 & 2.3 & .3 & 6.0 & 28 & 1.8 & 2.3 \\
\hline Streambed-right (GR151) & Sandy Run at S4 & 2.6 & 2.3 & .3 & 6.0 & 20 & 1.2 & 1.9 \\
\hline Streambed-right (GR150) & Sandy Run at S4 & 2.0 & 1.6 & .3 & 5.7 & 17 & 1.5 & 3.4 \\
\hline Streambank-right (GR153) & Sandy Run at S4 & 1.3 & 1.0 & .2 & 5.7 & 11 & 1.5 & 1.8 \\
\hline
\end{tabular}


Table 3. Screened intervals and median concentrations of selected chemical constituents in ground-water samples collected from aquifers and riparian zones at the Lizzie Research Station, North Carolina.-Continued

[NGVD 29, National Geodetic Vertical Datum of 1929; mg/L, milligram per liter; N, nitrogen; <, less than; - , no data. Units are milligrams per liter unless otherwise noted. Most samples were collected from March 1999 to June 2002]

\begin{tabular}{|c|c|c|c|c|c|c|c|}
\hline Well name & $\begin{array}{c}\text { Well name and location } \\
\text { shown in figure } 2 \\
\text { (several wells may be } \\
\text { colocated) }\end{array}$ & $\begin{array}{l}\text { Sodium } \\
\text { (mg/L) }\end{array}$ & $\begin{array}{l}\text { Bicar- } \\
\text { bonate } \\
(\mathrm{mg} / \mathrm{L})\end{array}$ & $\begin{array}{l}\text { Chloride } \\
\text { (mg/L) }\end{array}$ & $\begin{array}{l}\text { Silica } \\
\text { (mg/L) }\end{array}$ & $\begin{array}{l}\text { Sulfate } \\
\text { (mg/L) }\end{array}$ & $\begin{array}{l}\text { Ammonia } \\
\text { (as N) }\end{array}$ \\
\hline \multicolumn{8}{|c|}{ Surficial aquifer (unconfined) } \\
\hline L2 & L2 & 2.4 & 1 & 9.1 & 5.6 & 9.3 & $<0.04$ \\
\hline L2S & L2 & 5.3 & - & 10 & 6.7 & 3.4 & .12 \\
\hline L2D & $\mathrm{L} 2$ & 14 & 10 & 23 & 9.9 & 10 & $<.04$ \\
\hline L3 & $\mathrm{L} 2$ & 4.3 & 3 & 11 & 17 & 8.5 & $<.04$ \\
\hline L4 & L4 & 3.9 & 10 & 20 & 4.9 & 14 & $<.04$ \\
\hline $\mathrm{L} 4 \mathrm{~S}$ & L4 & 6.5 & 1 & 33 & 5.4 & 16 & $<.04$ \\
\hline L4D & L4 & 7.1 & 8 & 37 & 5.6 & 36 & $<.04$ \\
\hline L5 & L6 & 4.8 & - & 9.8 & 16 & 14 & $<.04$ \\
\hline L6 & L6 & 39 & 1 & 95 & 7.9 & 17 & $<.04$ \\
\hline L6S & L6 & 30 & 7 & 76 & 9.6 & 18 & .10 \\
\hline L6D & L6 & 7.4 & 2 & 10 & 13 & 17 & $<.04$ \\
\hline L9 & L9 & 5.2 & 38 & 26 & 13 & 60 & .03 \\
\hline L15 & L15 & 3.7 & - & 25 & 6.7 & 16 & $<.04$ \\
\hline L15D & L15 & 4.6 & 19 & 20 & 9.8 & 41 & $<.04$ \\
\hline L18D & L18 & 7.8 & 5 & 11 & 8.4 & 26 & $<.04$ \\
\hline L20 & L21 & 3.4 & 8 & 7.1 & 15 & .9 & .03 \\
\hline L22 & L22 & 7.2 & 226 & 5.1 & 33 & .8 & .03 \\
\hline L23 & L23 & 17 & 9 & 22 & 12 & 12 & .07 \\
\hline L24 & L23 & 17 & 293 & 20 & 37 & 5.1 & $<.04$ \\
\hline L27 & L27 & 2.1 & 3 & 3.4 & 4.7 & 1.3 & $<.04$ \\
\hline \multicolumn{8}{|c|}{ Alluvial aquifer (unconfined) } \\
\hline $\mathrm{L7}$ & L8 & 2.4 & 2 & 18 & 6.2 & 3.9 & $<0.04$ \\
\hline L8S & L8 & 2.1 & 1 & 17 & 6.5 & 6.3 & $<.04$ \\
\hline L8D & L8 & 2.7 & 2 & 15 & 6.4 & 34 & $<.04$ \\
\hline L11S & L11 & 2.3 & 4 & 9.2 & 2.8 & 8.6 & $<.04$ \\
\hline L11D & L11 & 2.1 & 1 & 24 & 3.4 & 16 & $<.04$ \\
\hline L11 & L11 & 2.2 & 4 & 8.3 & 2.4 & 9.0 & $<.04$ \\
\hline \multicolumn{8}{|c|}{ Yorktown aquifer (confined and unconfined) } \\
\hline L10 & L11 & 4.7 & 49 & 13 & 11 & 39 & $<0.04$ \\
\hline L12 & L12 & 8.5 & 200 & 5.5 & 35 & 5.2 & .07 \\
\hline L14 & L15 & 4.1 & 151 & 7.5 & 16 & 16 & $<.04$ \\
\hline L16 & $\mathrm{L} 4$ & 7.1 & 210 & 3.1 & 40 & 1.7 & .06 \\
\hline L17 & L18 & 6.4 & 184 & 3.4 & 29 & 3.2 & $<.04$ \\
\hline L19 & L21 & 4.9 & 198 & 4.1 & 25 & 1.1 & $<.04$ \\
\hline L26 & L27 & 17 & 193 & 4.2 & 25 & 6.2 & $<.04$ \\
\hline \multicolumn{8}{|c|}{ Peedee Formation (confined) } \\
\hline $\mathrm{L} 25$ & $\mathrm{~L} 23$ & 8.6 & 218 & 4.4 & 27 & 0.4 & 0.06 \\
\hline L55 & $\mathrm{L} 2$ & 4.1 & 116 & 7.0 & 23 & 5.0 & .02 \\
\hline \multicolumn{8}{|c|}{ Streambed and riparian zone } \\
\hline Streambed-center (GR089) & Drainage ditch at S3 & 7.1 & 23 & 27 & 16 & 3.1 & 0.09 \\
\hline $\begin{array}{l}\text { Riparian/upland boundary } \\
\text { (GR157) }\end{array}$ & FP & 9.0 & - & 29 & 6.6 & 11 & $<.04$ \\
\hline Streambed-center (GR155) & Plum Tree near FP & 6.9 & 54 & 41 & 8.2 & 4.3 & 1.1 \\
\hline Streambank-right (GR156) & Plum Tree near FP & 10 & 32 & 44 & 10 & 10 & .63 \\
\hline Streambed-center (GR149) & Plum Tree at S2 & 8.2 & 7.5 & 25 & 12 & 10 & .29 \\
\hline Streambed-center (GR148) & Plum Tree at S2 & 7.8 & 15 & 23 & 12 & 9.0 & .22 \\
\hline Streambed-center (GR152) & Sandy Run at S4 & 7.4 & 81 & 12 & 18 & 1.3 & .84 \\
\hline Streambed-right (GR151) & Sandy Run at S4 & 8.1 & 59 & 13 & 11 & 28 & .60 \\
\hline Streambed-right (GR150) & Sandy Run at S4 & 6.6 & 66 & 13 & 16 & 2.0 & 4.3 \\
\hline Streambank-right (GR153) & Sandy Run at S4 & 5.3 & 49 & 14 & 9.8 & .7 & 1.6 \\
\hline
\end{tabular}


Table 3. Screened intervals and median concentrations of selected chemical constituents in ground-water samples collected from aquifers and riparian zones at the Lizzie Research Station, North Carolina.-Continued

[NGVD 29, National Geodetic Vertical Datum of 1929; mg/L, milligram per liter; N, nitrogen; <, less than; —, no data. Units are milligrams per liter unless otherwise noted. Most samples were collected from March 1999 to June 2002]

\begin{tabular}{|c|c|c|c|c|c|c|c|}
\hline Well name & $\begin{array}{l}\text { Well name and location } \\
\text { shown in figure } 2 \\
\text { (several wells may be } \\
\text { colocated) }\end{array}$ & $\begin{array}{l}\text { Ammonia plus } \\
\text { organic } \\
\text { nitrogen } \\
\text { (as N) }\end{array}$ & $\begin{array}{l}\text { Nitrate } \\
\text { (as N) }\end{array}$ & $\begin{array}{l}\text { Phos- } \\
\text { phorus }\end{array}$ & Carbon & Iron & Manganese \\
\hline \multicolumn{8}{|c|}{ Surficial aquifer (unconfined) } \\
\hline $\mathrm{L} 2$ & $\mathrm{~L} 2$ & $<0.2$ & 4.1 & $<0.02$ & 0.6 & 0.21 & 0.01 \\
\hline $\mathrm{L} 2 \mathrm{~S}$ & L2 & .29 & 2.6 & $<.02$ & 1.4 & .17 & .01 \\
\hline L2D & $\mathrm{L} 2$ & $<.2$ & .89 & .02 & .5 & .63 & .05 \\
\hline L3 & $\mathrm{L} 2$ & $<.2$ & $<.05$ & .08 & .2 & 5.06 & .01 \\
\hline L4 & L4 & $<.2$ & 15 & $<.02$ & 6 & $<.003$ & .10 \\
\hline L4S & $\mathrm{L} 4$ & .21 & 19 & .18 & 1.4 & .02 & .17 \\
\hline L4D & $\mathrm{L} 4$ & .14 & 19 & .02 & 1.0 & .17 & .15 \\
\hline L5 & L6 & $<.2$ & .14 & $<.02$ & .2 & .79 & .02 \\
\hline L6 & L6 & .33 & 41 & .01 & 1.6 & .07 & .19 \\
\hline L6S & L6 & .36 & 35 & $<.02$ & 2.0 & .02 & .21 \\
\hline L6D & L6 & $<.1$ & .12 & $<.02$ & .3 & .70 & .02 \\
\hline L9 & L9 & $<.2$ & $<.05$ & .11 & .8 & 2.48 & .05 \\
\hline L15 & L15 & .14 & 12 & .02 & .7 & .02 & .06 \\
\hline L15D & L15 & $<.1$ & 1.4 & .04 & .3 & .06 & .10 \\
\hline L18D & L18 & .17 & .46 & .15 & .4 & .03 & .08 \\
\hline L20 & L21 & $<.2$ & $<.05$ & .27 & .6 & .66 & .01 \\
\hline L22 & L22 & $<.2$ & $<.05$ & .11 & .6 & 2.45 & .05 \\
\hline L23 & L23 & .24 & .07 & .03 & - & .31 & .01 \\
\hline L24 & L23 & .19 & $<.05$ & .06 & 3.2 & 1.49 & .04 \\
\hline L27 & L27 & $<.2$ & $<.05$ & .07 & .3 & .11 & .00 \\
\hline \multicolumn{8}{|c|}{ Alluvial aquifer (unconfined) } \\
\hline L7 & L8 & $<0.1$ & 11.8 & 0.50 & 0.3 & $<0.01$ & 0.03 \\
\hline L8S & L8 & $<.1$ & 11.6 & .05 & .4 & .01 & .03 \\
\hline L8D & L8 & $<.1$ & 6.5 & .70 & .4 & .05 & .05 \\
\hline L11S & L11 & $<.1$ & 5.2 & .02 & .6 & $<.01$ & .03 \\
\hline L11D & L11 & $<.1$ & 7.7 & .05 & .4 & .01 & .04 \\
\hline L11 & L11 & $<.1$ & 3.9 & .02 & .5 & - & .02 \\
\hline \multicolumn{8}{|c|}{ Yorktown aquifer (confined and unconfined) } \\
\hline L10 & L11 & 0.09 & 0.05 & 0.51 & 0.4 & 1.15 & 0.05 \\
\hline L12 & L12 & .09 & $<.05$ & .11 & .5 & .27 & .07 \\
\hline L14 & L15 & .38 & $<.05$ & .15 & .2 & .86 & .06 \\
\hline L16 & $\mathrm{L} 4$ & $<.2$ & $<.05$ & .06 & .4 & .29 & .06 \\
\hline L17 & L18 & .15 & $<.05$ & .13 & .4 & .93 & .09 \\
\hline L19 & $\mathrm{L} 21$ & $<.2$ & $<.05$ & .08 & .3 & 1.19 & .02 \\
\hline L26 & $\mathrm{L} 27$ & $<.2$ & $<.05$ & .28 & .7 & .83 & .02 \\
\hline \multicolumn{8}{|c|}{ Peedee Formation (confined) } \\
\hline $\mathrm{L} 25$ & $\mathrm{~L} 23$ & 0.16 & $<0.05$ & 0.12 & 0.6 & 1.2 & 0.08 \\
\hline L55 & $\mathrm{L} 2$ & .06 & $<.05$ & .15 & .3 & 2.3 & .06 \\
\hline \multicolumn{8}{|c|}{ Streambed and riparian zone } \\
\hline Streambed-center (GR089) & Drainage ditch at S3 & 0.28 & 0.63 & $<0.02$ & 2.4 & 8.0 & 0.04 \\
\hline $\begin{array}{l}\text { Riparian/upland boundary } \\
\text { (GR157) }\end{array}$ & FP & .11 & 6.4 & $<.02$ & 1.1 & .09 & .04 \\
\hline Streambed-center (GR155) & Plum Tree near FP & 1.5 & $<.05$ & .07 & 9.0 & 14 & .04 \\
\hline Streambank-right (GR156) & Plum Tree near FP & .99 & $<.05$ & .08 & 12 & 9.6 & .03 \\
\hline Streambed-center (GR149) & Plum Tree at S2 & .47 & $<.05$ & .12 & 4.3 & 8.2 & .03 \\
\hline Streambed-center (GR148) & Plum Tree at S2 & .32 & $<.05$ & .18 & 3.2 & 10 & .04 \\
\hline Streambed-center (GR152) & Sandy Run at S4 & .87 & $<.05$ & .89 & 2.7 & .04 & .20 \\
\hline Streambed-right (GR151) & Sandy Run at S4 & .65 & $<.05$ & .87 & 2.2 & .08 & .03 \\
\hline Streambed-right (GR150) & Sandy Run at S4 & 3.9 & $<.05$ & 1.0 & 25 & 4.1 & .04 \\
\hline Streambank-right (GR153) & Sandy Run at S4 & 2.0 & $<.05$ & .78 & 8.5 & 6.2 & .04 \\
\hline
\end{tabular}

${ }^{a}$ For streambed and riparian wells, screen interval is given as depth below land surface, in feet. 


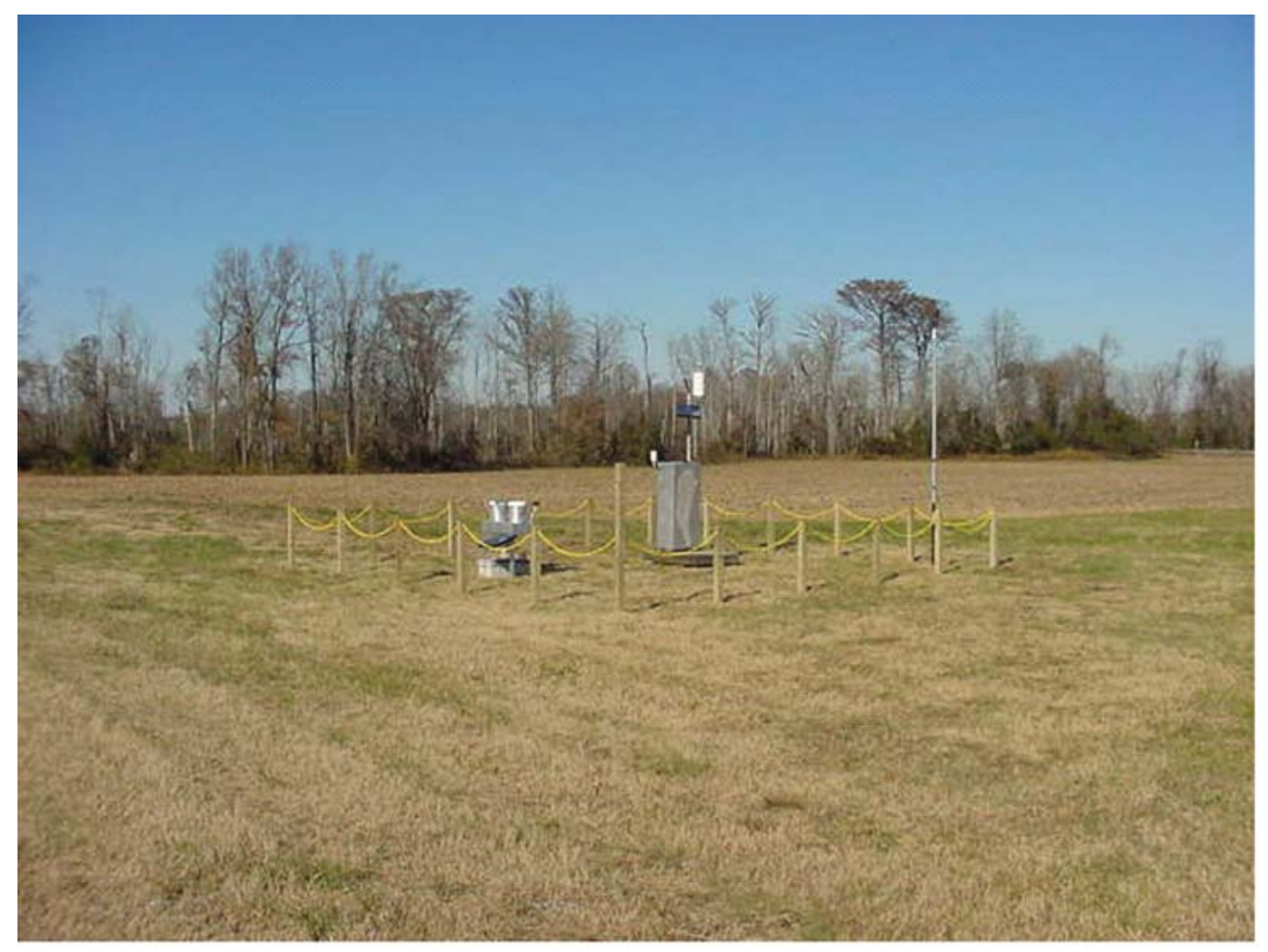

Figure 3. Weather station at the Lizzie Research Station, North Carolina.

\section{Sample Collection and Analysis}

Surface-water-quality samples and discharge measurements were collected approximately monthly at the six primary sampling sites beginning in April 1999 and continuing through September 2002; samples were collected at the remaining nine sites approximately monthly or more frequently beginning in June 2000 and continuing through September 2002. Selected precipitation events also were targeted to obtain additional samples during various flow conditions. Surfacewater samples were collected and processed according to procedures presented in Wilde and others (1998). During sample collection, field measurements of $\mathrm{pH}$, dissolved oxygen, specific conductance, and temperature were obtained. Total nitrogen and total phosphorus concentration data were collected from surface-water stations (figs. 1, 2) and used for load calculations (table 2). A summary of selected chemical constituents at ground-water sites is presented in table 3 . Selected data for inert gases and tritium collected at groundwater sites and used for age dating the water are listed in table 4. Surface-water sampling sites instrumented by the USGS include a drainage ditch (S3), Plum Tree Branch (S2), Sandy Run (S4), and Middle Swamp (S5, fig. 2). Ground-waterquality sampling was conducted according to the USGS NAWQA protocols (Koterba and others, 1995). Submersible or peristaltic pumps and Teflon lines were used for all waterquality sampling except for chlorofluorocarbon (CFC) sampling for which copper tubing was used.
Dissolved-oxygen concentrations and $\mathrm{pH}$ were measured using electrodes placed in a flow cell chamber to minimize atmospheric interactions. Alkalinity was determined in the field by titration. Water samples for major ions and nutrients were filtered using a 0.45 -micrometer $(\mu \mathrm{m})$ capsule filter. Sulfate $\left(\mathrm{SO}_{4}{ }^{2-}\right)$ was analyzed by ion chromatography. Magnesium, silica $\left(\mathrm{SiO}_{2}\right)$, iron, and manganese were analyzed by using inductively coupled plasma and mass spectrometry (ICP/MS). Nitrate, nitrite, ammonium, and bromide were analyzed by using colorimetric methods. Detailed descriptions of the analytical methods for the above-mentioned major ions and nutrients are provided in Fishman and Friedman (1989). Dissolved organic carbon was analyzed by ultraviolet promoted persulfate oxidation and infrared spectrometry (Brenton and Arnett, 1993). All of the above-listed analyses were conducted at USGS laboratories in Denver, Colorado, and Ocala, Florida. Samples for CFCs (trichlorofluoromethane, CFC-11; dichlorodifluoromethane, CFC-12; trichlorotrifluoroethane, CFC-113) and dissolved gases (nitrogen and argon) were collected and analyzed as described in Busenberg and Plummer (1992) and Busenberg and others (1993), respectively. A list of all sites sampled for this study and accessibility of the data is presented in Appendix 1. Data for major ions, nutrients, streamflow, stream stage, precipitation, wind speed, and wind direction have been published previously (U.S. Geological Survey, 1999-2002). 
Table 4. Recharge dates and concentrations of dissolved gases and tritium in ground-water samples collected at the Lizzie Research Station, North Carolina.

[pCi/L, picocurie per liter; pg/kg, picogram per kilogram; <, less than; _, no data; >, greater than. Units are milligrams per liter unless otherwise noted. Most samples were collected from March 1999 to June 2002]

\begin{tabular}{|c|c|c|c|c|c|c|c|c|c|}
\hline Well name & $\begin{array}{l}\text { Well location } \\
\text { (fig. 2) }\end{array}$ & $\mathrm{CH}_{4}$ & $\mathbf{N}_{2}$ & Ar & $\begin{array}{c}\text { Excess } \\
\mathrm{N}_{2}\end{array}$ & $\begin{array}{l}\text { Tritium } \\
\text { (pCi/L) }\end{array}$ & $\begin{array}{l}\text { CFC-12 } \\
\text { (pg/kg) }\end{array}$ & $\begin{array}{l}\text { Recharge } \\
\text { date }\end{array}$ & $\begin{array}{l}\text { Age-dating } \\
\text { method }\end{array}$ \\
\hline \multicolumn{10}{|c|}{ Surficial aquifer (unconfined) } \\
\hline L3 & L2 & .001 & 22.6 & .695 & 1.8 & 29 & 14 & 1958 & CFC-12 \\
\hline L6S & L6 & .002 & 18.8 & .646 & $<1$ & 26 & 259 & 1990 & CFC-12 \\
\hline L6D & L6 & $<.001$ & 22.8 & .668 & 3.6 & 48 & 75 & 1971 & CFC-12 \\
\hline L15D & L15 & .005 & 24.3 & .635 & 7 & 30 & 236 & 1987 & CFC-12 \\
\hline L20 & $\mathrm{L} 21$ & .014 & 21.3 & 681 & 1.3 & 36 & 12 & 1957 & CFC-12 \\
\hline L23 & L23 & - & - & - & - & 29 & - & $>1953$ & Tritium \\
\hline $\mathrm{L} 24$ & L23 & - & - & - & - & $<1$ & - & $<1955$ & Tritium \\
\hline L27 & L27 & $<.001$ & 17.3 & .650 & $<1$ & 18 & 256 & 1989 & $\mathrm{CFC}-12$ \\
\hline \multicolumn{10}{|c|}{ Alluvial aquifer (unconfined) } \\
\hline L7 & L8 & $<0.001$ & 17.7 & 0.630 & $<1$ & 23 & 284 & 1994 & CFC-12 \\
\hline L8S & L8 & $<.001$ & 16.0 & .595 & $<1$ & 19 & 288 & 1995 & CFC-12 \\
\hline L8D & L8 & $<.001$ & 19.3 & .638 & 1.9 & 22 & - & - & - \\
\hline L11D & L11 & $<.001$ & 19.1 & .685 & $<1$ & 19 & - & $1992^{\mathrm{a}}$ & $\mathrm{SF}_{6}$ \\
\hline \multicolumn{10}{|c|}{ Yorktown aquifer (confined and unconfined) } \\
\hline L10 & L11 & 0.155 & 27.3 & 0.667 & 8.2 & 28 & 108 & 1974 & CFC-12 \\
\hline L14 & L15 & .002 & 22.3 & .704 & 1.1 & 10 & 19 & 1960 & CFC-12 \\
\hline L16 & L4 & .011 & 22.1 & .743 & $<1$ & $<1$ & 2 & 1948 & CFC-12 \\
\hline L17 & L18 & .004 & 21.7 & .732 & $<1$ & $<1$ & - & $<1955$ & Tritium \\
\hline L19 & $\mathrm{L} 21$ & .003 & 22.4 & .743 & $<1$ & $<1$ & 5 & 1952 & CFC-12 \\
\hline L26 & L27 & $<.001$ & 21.7 & .722 & $<1$ & 2.6 & 32 & 1955 & Tritium \\
\hline \multicolumn{10}{|c|}{ Peedee aquifer (confined) } \\
\hline $\mathrm{L} 25$ & L23 & 0.003 & 23.0 & 0.752 & $<1$ & $<1$ & - & $<1955$ & Tritium \\
\hline L55 & $\mathrm{L} 2$ & .006 & 23.0 & .742 & $<1$ & 11 & 9 & 1955 & CFC-12 \\
\hline \multicolumn{10}{|c|}{ Streambed and riparian zone } \\
\hline Streambed-center (GR089) & Drainage ditch at S3 & $0.001^{\mathrm{b}}$ & $17.2^{b}$ & $0.531^{\mathrm{b}}$ & - & - & - & - & - \\
\hline Riparian/upland boundary (GR157) & FP & .011 & 20.1 & .632 & - & - & - & - & - \\
\hline Streambed-center (GR155) & Plum Tree near FP & $.002^{\mathrm{b}}$ & $11.5^{\mathrm{b}}$ & $.364^{\mathrm{b}}$ & - & - & - & - & - \\
\hline Streambank-right (GR156) & Plum Tree near FP & .011 & 20.1 & .638 & - & - & - & - & - \\
\hline Streambed-center (GR149) & Plum Tree at $\mathrm{S} 2$ & $.090^{\mathrm{b}}$ & $16.3^{\mathrm{b}}$ & $.542^{\mathrm{b}}$ & - & - & 51.8 & 1968 & CFC-12 \\
\hline Streambed-right (GR150) & Sandy Run at S4 & $14.7^{\mathrm{b}}$ & $2.2^{\mathrm{b}}$ & $.105^{\mathrm{b}}$ & - & - & - & - & - \\
\hline
\end{tabular}

${ }^{\mathrm{a}} \mathrm{CFC}-12$ contamination is suspected. Recharge date is based on $\mathrm{SF}_{6}$ data.

${ }^{\mathrm{b}} \mathrm{Samples}$ have outgassed. Values given underestimate actual concentrations. 


\section{Load Estimation Methods}

The transport (mass discharge) of a constituent past a monitoring site in a given amount of time is referred to as the constituent load. Constituent loads were estimated by the rating-curve method (Cohn and others, 1989; Crawford, 1991). Because some of the constituent concentrations included in this assessment were less than the detection limit, parameters of the rating curve were estimated by maximum-likelihood methods (Dempster and others, 1977; Wolynetz, 1979) or the linearattribution method (Chatterjee and McLeish, 1986). An estimate of the uncertainty in the estimated loads was obtained by using the method described by Likes (1980) and Gilroy and others (1990) for maximum-likelihood estimates and by the jackknife method (Efron, 1982) for linear-attribution estimates. A detailed description of these methods is presented in Crawford (1996).

Estimates of annual mass loads at 13 stations were made using the procedures referred to above. The eight models considered in the model-selection procedure are:

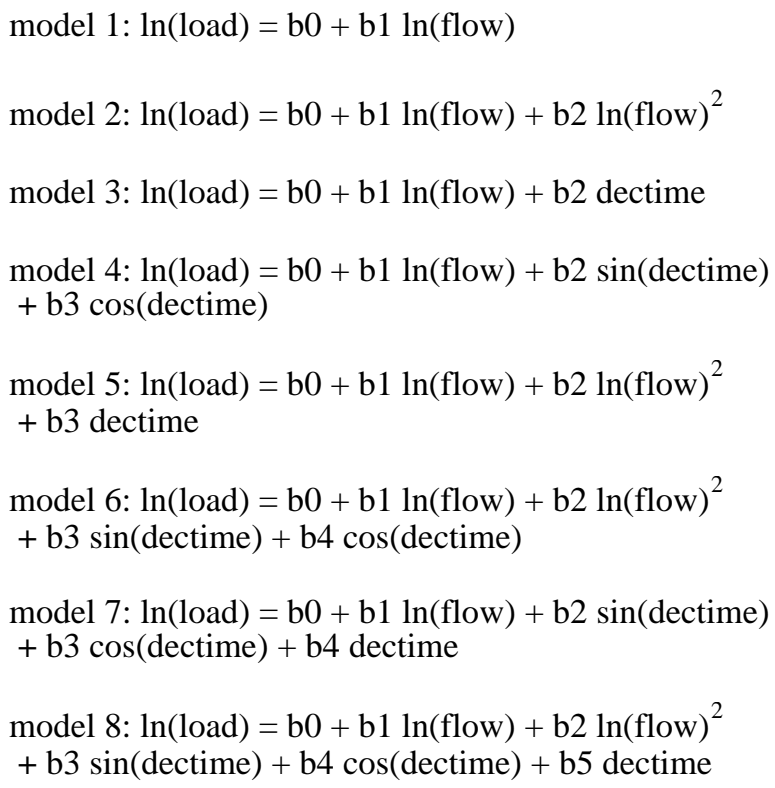

The natural logarithm of the load is considered as a function of up to eight combinations of parameters representing discharge (flow and flow ${ }^{2}$ ), time (dectime), and seasonality ( $\sin$ [dectime] and cos[dectime]), which best account for the variability of constituent concentrations. The $b$ parameters, or regression coefficients, of the model are estimated from the data. The best model is selected automatically in the USGS load estimator program (Loadest) subroutines implemented in S-Plus ${ }^{\mathrm{TM}}$. When the log-transformed loads are converted back to daily loads, one of four estimators - the Adjusted Maximum Likelihood Estimator (AMLE), Maximum Likelihood Estimator (MLE), Least Absolute Deviation (LAD), or Linear Attribution (LA) — is selected by the program, depending on the distribution of the residuals. Seasonal loads were computed by summing loads for winter (December-February), spring
(March-May), summer (June-August), and fall (SeptemberNovember).

Because not enough continuous-flow data and samples were available for Plum Tree Branch (site S2, fig. 2; tables 1, 2) for use with Loadest, the mean daily discharge for calendar year 2000 was multiplied times the annual median concentration for both total nitrogen and total phosphorus and summed to obtain an annual load estimate. Confidence intervals for total nitrogen and total phosphorus loads and estimation methods used for each station are given in Appendix 2.

In order to obtain an estimate of the accuracy of the loadestimation procedures used in this report, USGS gaging-station flow data and USGS nitrate data collected approximately twice monthly in 2001 from the Neuse River near Fort Barnwell (site N3, fig. 1) were compared to the estimated loads, using hourly data, collected by North Carolina State University (NCSU), Raleigh, N.C. Hourly measurements of nitrate, $\mathrm{pH}$, dissolved oxygen, and other constituents were measured by NCSU as part of the River Net Program in 2001 (William Showers, North Carolina State University, written commun., 2003). These data are available at http://rivernet.ncsu.edu/ index.html. Using hourly NCSU nitrate data collected by a continuous sampler/analyzer in conjunction with USGS daily discharge data for the same site, the hourly NCSU nitrate concentrations were averaged into daily values and analyzed by using the load-estimation procedures described for stations included in this report.

The annual nitrate load, using the 365 daily average concentrations and flows for 2001, was 1,138 tons. When only 21 daily nitrate values from USGS discrete water-quality samples were used to calculate the annual nitrate load at Fort Barnwell using the same load-estimation procedures, the result was 963 tons for 2001, about 15 percent lower than the results for the complete data set. In addition, the annual nitrate load for the Neuse River near Fort Barnwell also was computed by summing all 365 daily nitrate loads, using the nitrate data from NCSU and flow data from the USGS. The resulting load ( 1,148 tons) is considered to be the best estimate of the true load because it includes all days with daily mean nitrate concentrations and all days with mean flow-it is simply a direct numeric integration of all flow and concentration data (Richards, 1997). Thus, the USGS estimate, using only 21 samples, is about 16 percent lower than the true load computed using all data. The observed difference between the estimated loads is probably because the load estimate based on the 21 samples collected by the USGS included only 5 percent of the 365 samples collected by NCSU and did not cover the entire range of flow events. Specifically, the lack of samples during high flows may result in estimates that are somewhat low, particularly when the regression approach is used (Richards, 1997). Based on this brief comparative analysis, however, loads for this report are expected to be within 15 to 20 percent of the true loads transported.

Flow was generated at stations for streams that were not gaged, including Contentnea Creek near Evansdale (site S14, 
fig. 1) and Little Contentnea Creek at Scuffleton (S16, fig. 1). Daily flow values at Evansdale were estimated using daily mean flow data from Contentnea Creek at Hookerton (S18, fig. 1) by proportion of drainage area (flow at Evansdale $=$ $0.359 \times$ flow at Hookerton). Similarly, flows at Scuffleton (S16, fig. 1) were generated using flow data from Contentnea Creek near Willow Green (S6, fig. 1) (flow at Scuffleton $=1.13 \times$ flow at Willow Green).

Flows from tidally affected streams also must be corrected because of periodic flow reversals. Swift Creek is tidally influenced near Streets Ferry, and several reported daily flow values were negative. Because positive daily flows were required for analysis, unit values recorded every 15 minutes were filtered and modeled to generate positive daily net flows.

\section{Acknowledgments}

The U.S. Environmental Protection Agency, through its Office of Research and Development, partially funded the research described in this report through Interagency Agreement DW14938792-01 to the U.S. Geological Survey.

The authors acknowledge Dr. H.E. "Ted" Mew, Jr., (1942-2005), a friend and colleague, whose knowledge and insights contributed greatly to the concepts and ideas presented in this report. The work conducted at the Lizzie Research Station would not have been possible without his tireless enthusiasm and dedication.
The authors would like to thank all of the landowners who graciously allowed access to their property. Thanks also to Scott Caldwell, Terry Middleton, and Cassandra Pfeifle of the U.S. Geological Survey for their dedication and long hours toward maintaining instrumentation and collection of hydrologic and water-quality data during the study. Finally, the authors greatly appreciate comments and suggestions of the numerous reviewers of the manuscript who provided new perspectives on many topics that were incorporated into the final report.

\section{Hydrogeology, Geochemistry, and Nitrogen Transport at the Lizzie Research Station Study Site}

The Lizzie Research Station study site is in the Coastal Plain Physiographic Province (fig. 1, inset map), a landscape characterized by a series of progressively younger paleoshorelines and intervening terraces that step down in altitude and age toward the coast and into drainages. The relic landscape is mostly of Pliocene through Quaternary age, with modern drainages bordered by a series of nested Plio-

Pleistocene paleovalleys that are separated by remnants of older interfluves. The Lizzie site straddles the boundary between the Wicomico plain interfluve (60 to 90-ft terrace lying east of the Surry Scarp paleoshoreline, toe at $90 \mathrm{ft}$ [Daniels and Kane,

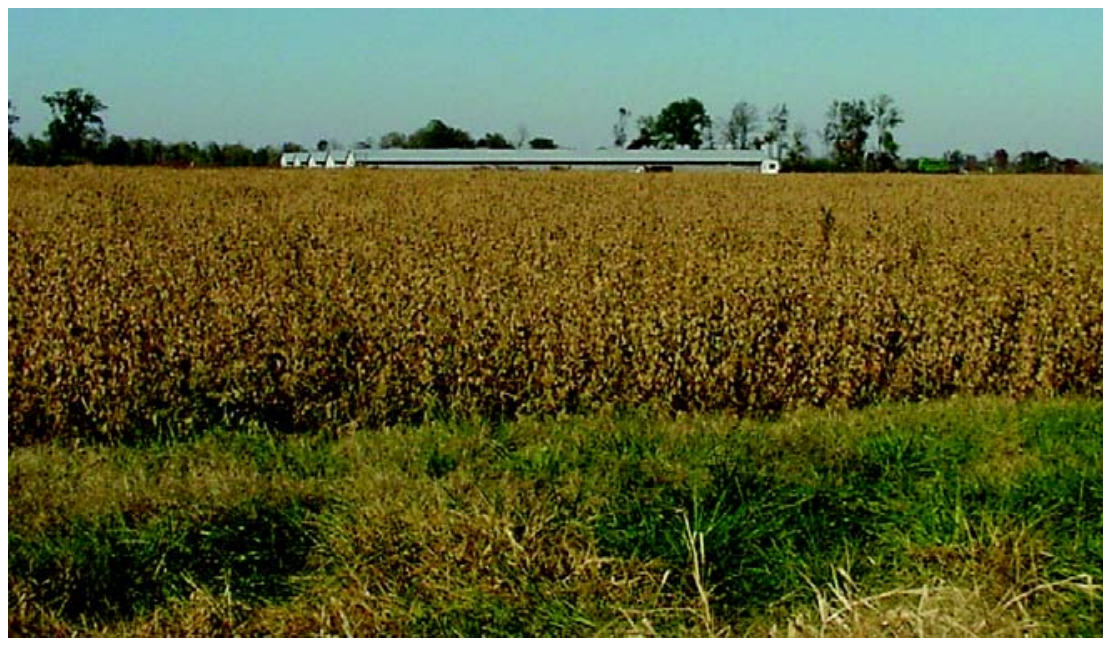

Hog houses in Greene County, North Carolina. 
2001]) and the 36-ft Sandy Run flood plain, with two sets of lower terraces separated by the 60-ft and 48-ft scarps (fig. 4A; cross-section A-A' in fig. 2; Farrell and others, 2003).

Landforms characterizing the Plum Tree Branch watershed include the poorly drained, wet flat upland headwaters, known locally as Half Moon Pocosin, and the generally well to moderately well drained, dry flat uplands and valley side slopes composing the Plum Tree Branch upland valley. Plum Tree Branch drains into Sandy Run, an alluvial paleovalley with riverine landforms along the valley bottoms.
At the Lizzie Research Station site, a Late Cretaceous marine shelf deposit resembling the Peedee Formation functions as the lower boundary for the shallow ground-water system of near-surface aquifers and confining units (fig. 4B). Overlying the Cretaceous section is the Pliocene-age Yorktown Formation and several poorly exposed Pliocene to Pleistocene units that are difficult to age date and correlate because of widespread carbonate dissolution. Stephenson and Johnson (1912) prepared the first detailed hydrogeologic maps of ground-water resources in the North Carolina Coastal Plain,

A.

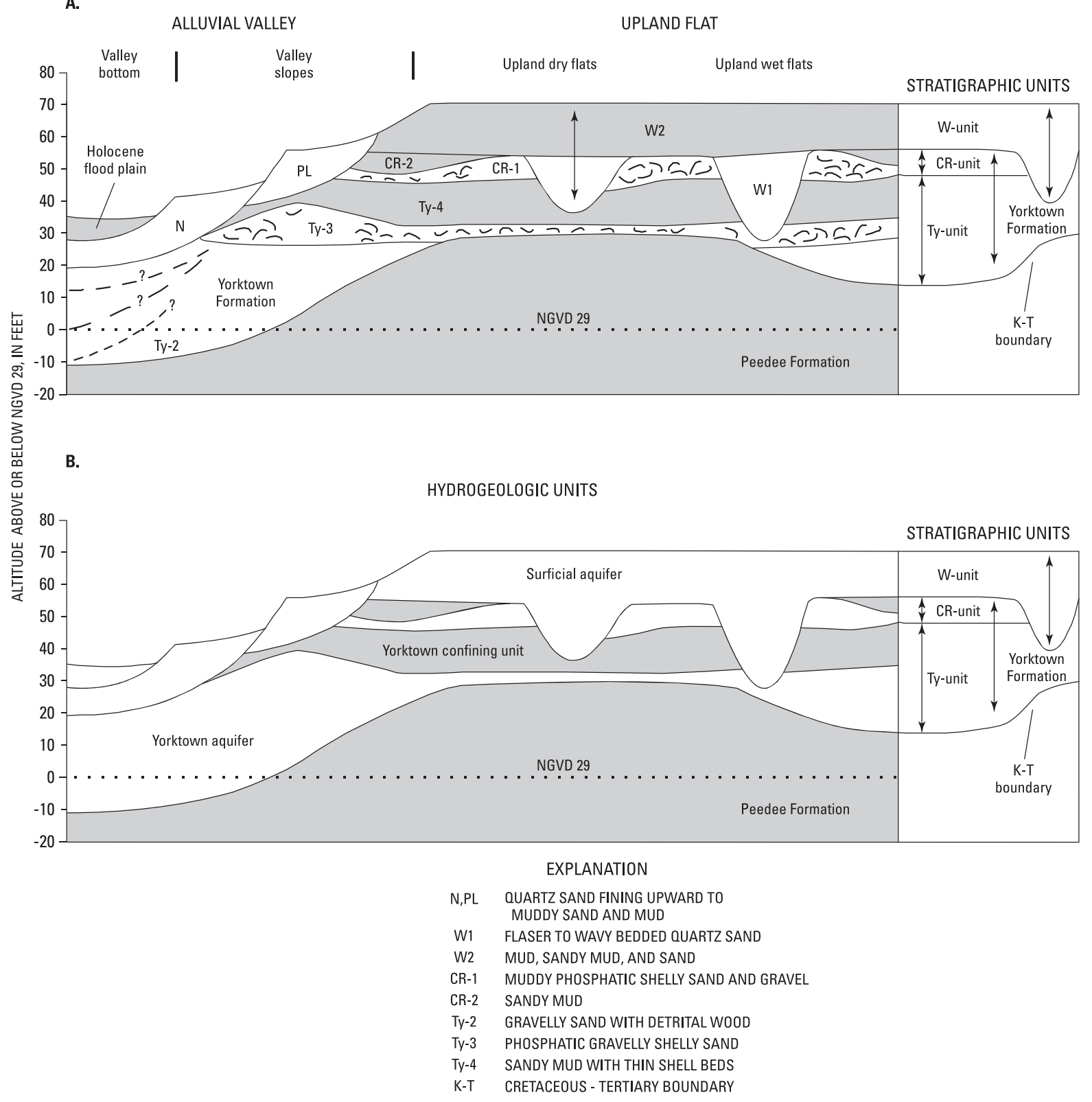

Figure 4. Conceptual models of $(A)$ stratigraphy and $(B)$ hydrogeologic units of the Lizzie Research Station, North Carolina. 
associating the surficial aquifer with Pleistocene terrace deposits, and equated the first confining unit and underlying confined aquifer with the Yorktown Formation. More recently, the surficial aquifer was generalized to include post-Yorktown deposits of Quaternary age (Winner and Coble, 1996).

The Yorktown aquifer is composed of gravelly sands and a phosphatic gravelly, shelly sand, overlain by a sandy clayey silt with beds of Mulinia congesta that function as the 3 to $21-\mathrm{ft}$ thick Yorktown confining unit. The tidally bedded surficial deposits of the Wicomico plain form the upland surficial or terrace aquifer at the Lizzie site. These deposits of medium- to fine-grained flaser-bedded sand and silt initially settled into low-lying depressions in the relic landscape, infilling paleovalleys and other channel-like features that cut into the Yorktown. Overlying these sands is a sheet of heterogeneous, extensively bioturbated, 2 to 6-ft thick, surficial layer of tidal flat or interdistributary bay-like deposits that evolve upward into salt-marsh deposits.

Within the Sandy Run paleovalley, earlier erosion truncated the surficial and Yorktown formations, and the Yorktown confining unit completely is eroded below the 50-ft scarp. Subsequent middle Pleistocene fluvial to estuarine deposition, associated with sea-level rises, overlaid fine to coarse sands in the valley. Modern flood-plain deposits rich in detrital plant debris form a riparian zone along Sandy Run and lower portions of Plum Tree Branch. Hydrologically, the paleovalley substrate breaches the Yorktown confined aquifer and functions as an unconfined alluvial valley aquifer. As determined during the current study, water from the alluvial aquifer in Sandy Run and Middle Swamp was found to be chemically distinct from both the surficial and Yorktown aquifers.

The principal shallow aquifer, termed the surficial aquifer, includes several post-Yorktown units (W, PL, and $\mathrm{N}$ units, fig. 4) that are likely Pleistocene in age. These surficial units are underlain by the areally extensive Yorktown confining unit (Ty-4 - Morgarts Beach Member) and the Yorktown aquifer (Ty-2, Ty-3). The Yorktown aquifer includes two facies (Ty-2 and Ty-3). Because the Yorktown confining unit is eroded along the Sandy Run and Middle Swamp drainages, the Yorktown aquifer (Ty-2 and Ty-3) is unconfined in these areas and is connected to the surficial aquifer.

Head values for December 13, 2000, are shown for the surficial and Yorktown aquifers (fig. 5). Flow directions in the surficial aquifer indicate that much of the ground water underlying the western part of the study site discharges to Plum Tree Branch. Along the southeast-northwest cross-section B-B' (fig. 2), large downward gradients occur between the surficial and Yorktown aquifers as the stream is approached, indicating that ground water from the Yorktown does not discharge to Plum Tree Branch (fig. 6B). Plum Tree Branch does not breach the Yorktown confining unit (fig. 6B) but flows above it. Direct
A. Surficial aquifer

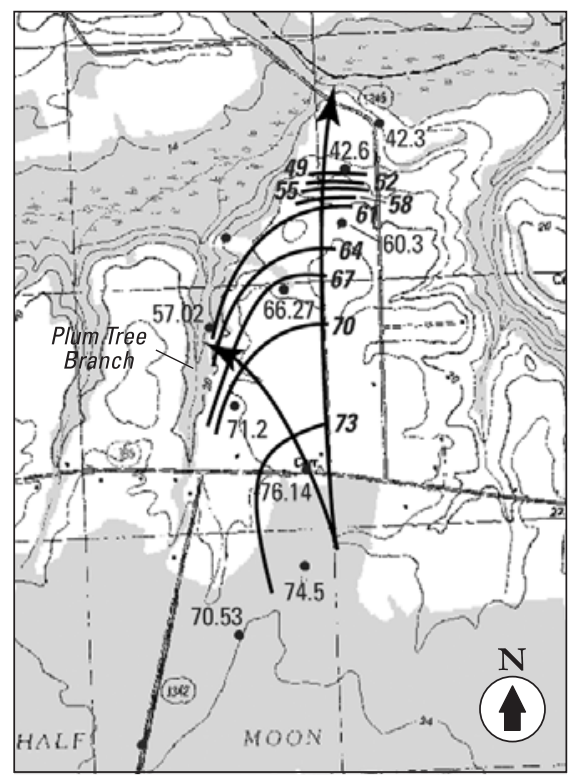

Base from digital files of

U.S. Geological Survey

Digital Raster Graph, Farmville Quad

$1: 24,000$
B. Yorktown aquifer

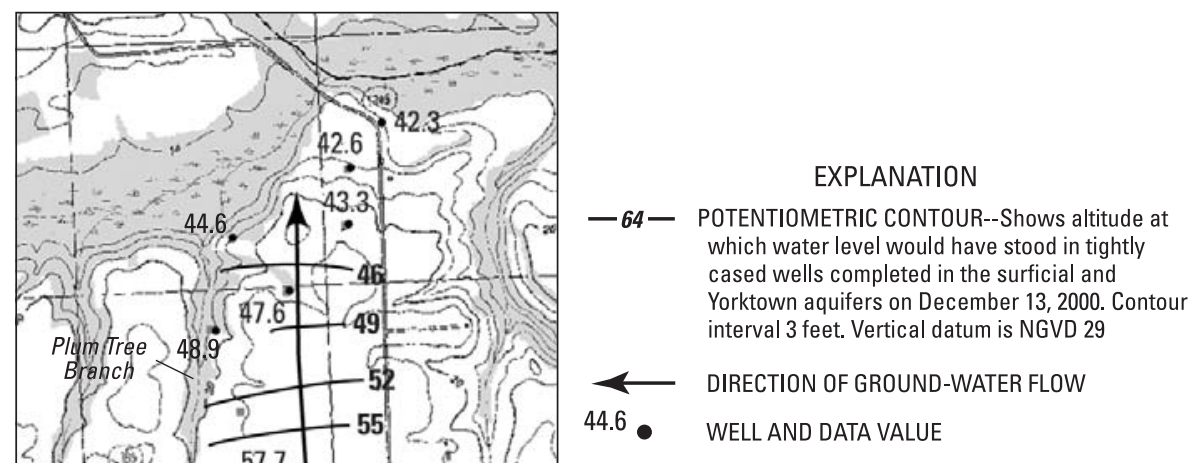

Figure 5. Piezometric head values and contours (in feet above NGVD 29) and flow directions for the (A) surficial and (B) Yorktown aquifers on December 13, 2000, at the Lizzie Research Station, North Carolina. 
discharge to streams also occurs along the northern part of the site, with flow to both Sandy Run and Middle Swamp. Head differences between the surficial and Yorktown aquifers along the south-north cross-section A-A' (fig. 2) are several feet in the upland areas but decrease to less than $0.3 \mathrm{ft}$ along the slope toward the alluvial valley (fig. 6A). Beneath this alluvial valley, the confining unit has been eroded, and the Yorktown aquifer sediments have been overlain by fluvial to estuarine deposits, creating a 45- to 50-ft thick unconfined alluvial aquifer.

Three distinct flow regimes are present at the site and can be characterized by the overlying landscape settings-poorly drained upland wet flats, moderate to well-drained upland valleys, and broad riverine alluvial valleys. These landscape features typically are found in the middle Coastal Plain environment and have been mapped across the entire North Carolina Coastal Plain (Haven, 2003). A pocosin is present at the upgradient end of the transect.

Flow is largely horizontal in the surficial aquifer underlying the upland flats and valley slopes to Plum Tree Branch, with seeps observed roughly $300 \mathrm{ft}$ south of toe-slope well L4 (fig. 2) during wetter periods of the year. Downward flow occurs along the terraced valley slopes to the Sandy Run

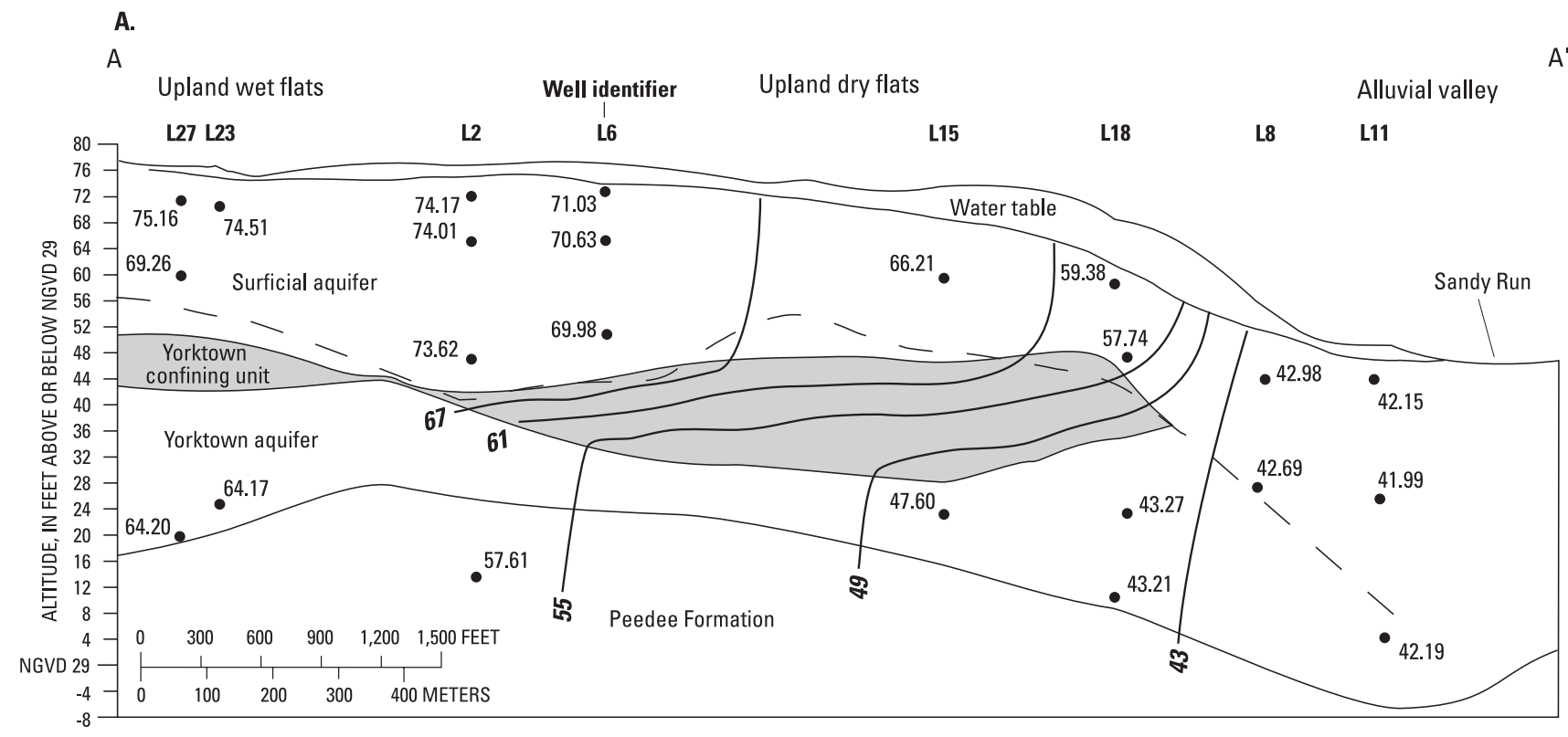

B.

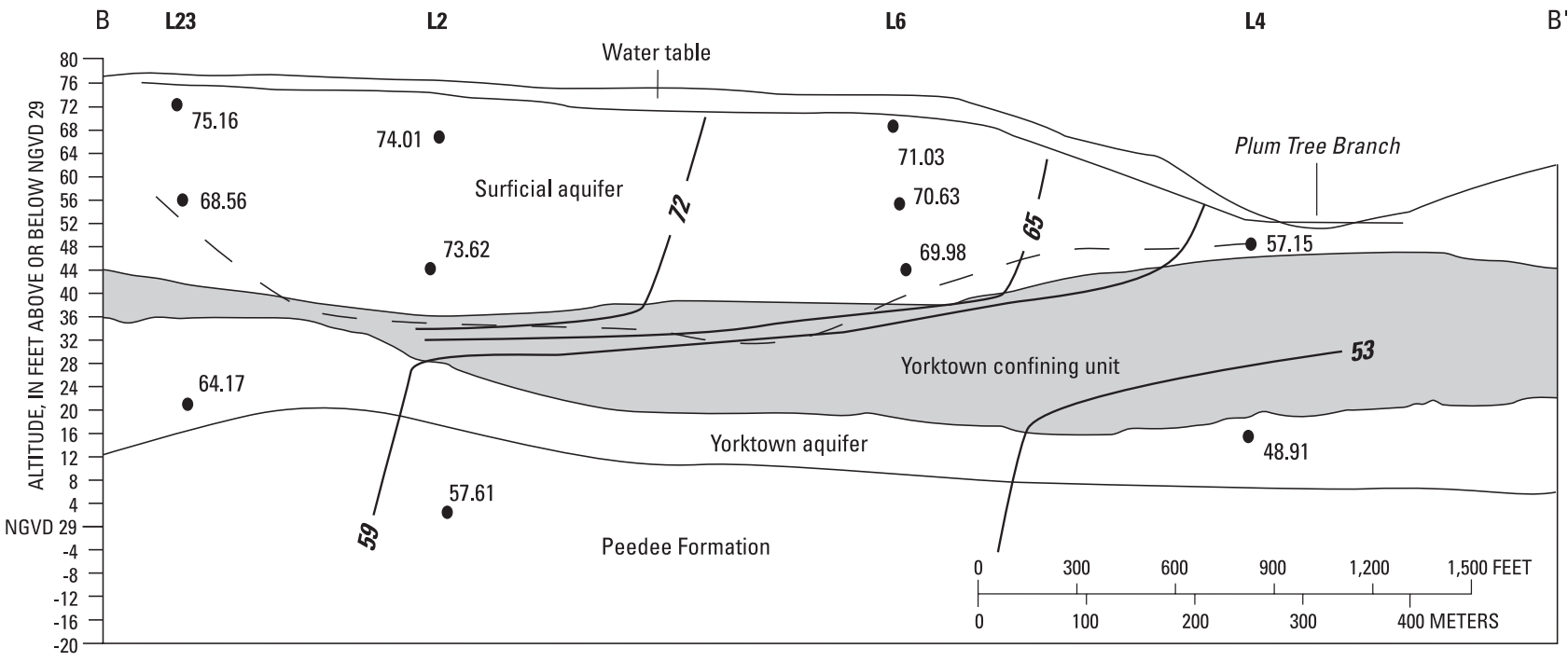

Figure 6. Piezometric head values and contours (in feet above NGVD 29) along (A) cross-section A- $A^{\prime}$ and (B) cross-section B-B'. 
bottomlands. The confining unit along this slope has been significantly leached and likely has increased the hydraulic conductivity of the unit in this area. Seeps have not been observed at the outcrop of the confining unit, as would be expected if the unit were to retard the downward migration of water. The chemistry (for example, $\mathrm{pH}$, alkalinity) of samples collected from this zone are similar to those from the surficial aquifer, which supports the conclusion that the confining unit has been leached by the more acidic water present in the surficial aquifer.

\section{Ground-Water Age-Dating, Chemistry, and Nitrogen Fate and Transport}

The date that ground water recharges an aquifer (defined as the time the water loses contact with the atmosphere) can provide information on the prevailing flux through the groundwater flow system and the fate of contaminants. The residence time of ground water and surface water was estimated based on concentrations of as many as three chemical markers: chlorofluorocarbons (CFCs), tritium, and silica (Tesoriero and others, 2005). Concentrations of CFCs increased in the atmosphere beginning in the 1940s when they were produced for a variety of uses (for example, propellants, aerosols) until recently when restrictions on CFC production were established. CFCs have been successfully used to track changes in contaminants over time (for example, Böhlke and Denver, 1995; Tesoriero and others, 2000). Chlorofluorocarbons and tritium concentrations in ground water were measured to estimate the age since the time of recharge.

Not surprisingly, the poorly drained upland or pocosin has a recharge age profile indicative of slow percolation rates. Recharge-age isopleths are tightly spaced with old (before 1955) ground water occurring at the base of the aquifer (fig. 7A; table 4). In contrast, along the intermediate part of the flow system, moderately well-drained soils are present, and faster recharge is indicated by the spreading of the recharge-age isopleths. Ground water at the base of the surficial aquifer is approximately 30 years old. Piezometric head values indicate that as Sandy Run is approached, incision of the surficial aquifer increases and the vertical component of ground-water flow increases (fig. 6).

Along the alluvial valley slopes, recent recharge-date isopleths occur at greater depths than in upland areas indicating that the alluvial aquifer is a recharge area. Upwelling of older water toward streams is not indicated by these data, as upwelling would result in the presence of older water as the stream is approached. The young age of ground water in the alluvial aquifer is consistent with the hypothesis that water in this aquifer is derived from short flow paths originating from directly above or from movement of water from Sandy Run and(or) Middle Swamp into the aquifer.
Tritium concentrations in the atmosphere are derived from atmospheric testing of nuclear weapons. As such, tritium is a particularly helpful marker of whether recharge occurred before or after the onset of atmospheric testing (approximately 1953). The intensity of atmospheric testing has varied since its inception. Using a chronological record of atmospheric tritium concentrations and the half life for tritium (12.4 years), a profile of expected tritium concentrations as a function of groundwater age has been constructed for this site. When both a tritium concentration and a CFC-based ground-water age were available, observed and expected tritium concentrations were compared to provide an independent test of the validity of the CFC-based ground-water ages (fig. 8). Nondetectable levels of tritium for CFC-based ages prior to 1953 provide a definitive verification that these samples represent water recharged prior to 1953. Tritium levels as a measure of the accuracy of CFC ages become less quantitative with more recent age dates because a single tritium level may represent recharge from widely different time periods. Further, mixing of water from different ages can have a dramatic effect on tritium levels because of the non-uniform tritium profile caused by bombtesting peaks.

With a few exceptions, tritium levels in ground water match the value expected by CFC-based age. No tritium was detected in samples with CFC-based recharge ages prior to 1953. As has been observed elsewhere (Böhlke and Denver, 1995), tritium levels that correspond to the bomb peak in the late 1960s were not found and may be a result of the mixing of waters recharged during the bomb peak with waters either before or after the peak. Although sample L26 has a CFC age of 1964, it has too little tritium to have recharged at that time (fig. 8). The sample has tritium levels consistent with recharge in the early 1950s. Although peak tritium levels were not observed when tritium concentrations were plotted in crosssection A-A' (fig. 7B), the higher concentrations of tritium observed at the base of the surficial aquifer (except beneath the upland wet flats) correspond to CFC-based ages that are consistent with bomb peak periods. The nondetectable concentrations of tritium at the base of the surficial aquifer beneath the upland wet flats is consistent with the slow rate of recharge that is expected in this part of the aquifer.

Geochemical tracers also have been used to determine the relative amounts of streamwater derived from different flow paths. Flow paths in a watershed range from short overland flow paths on the order of hours to long ground-water flow paths on the order of years. Silica $\left(\mathrm{SiO}_{2}\right)$ has been used as a chemical tracer because these pathways often have distinctly different silica concentrations, which tend to increase as a function of residence time. The availability of silica and age-dating information provides an opportunity to determine the relation between silica concentrations and residence time, which is typically modeled (Scanlon and others, 2001). Silica 
A. A

Upland wet flats

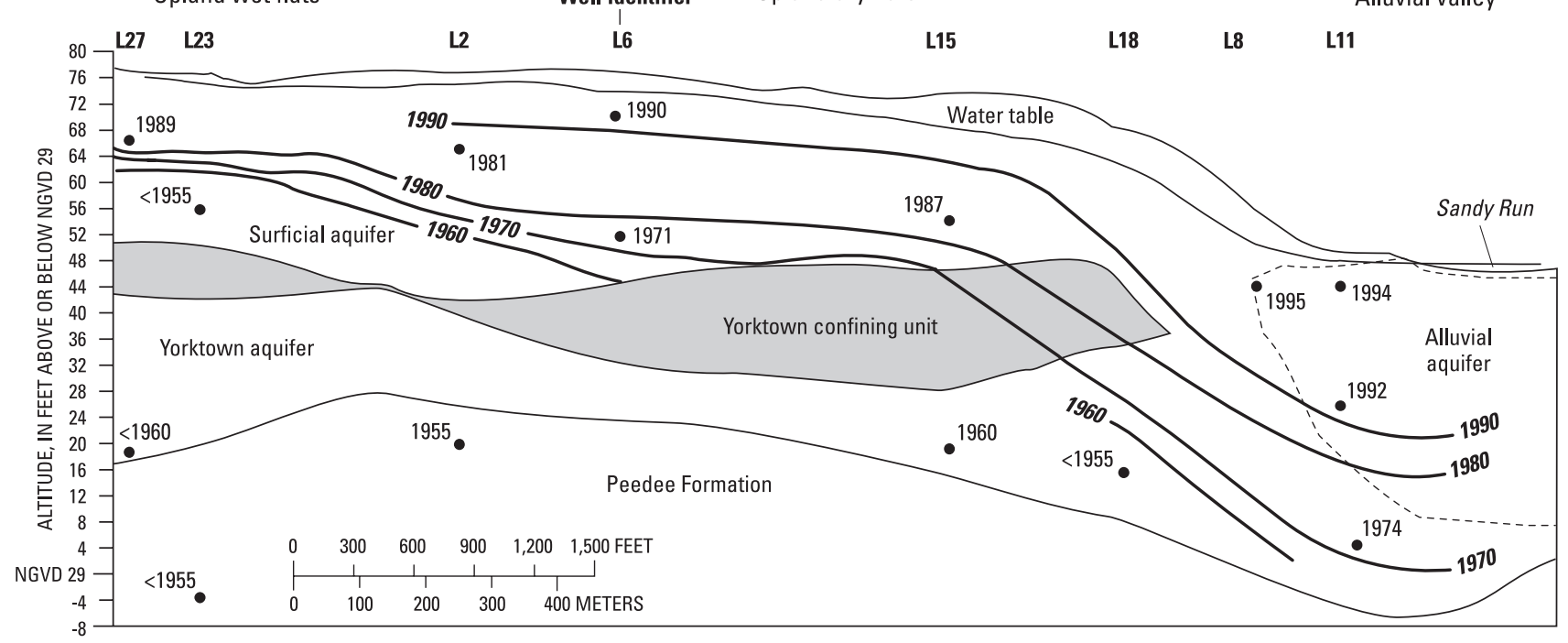

B. A

Upland wet flats

Well identifier Upland dry flats

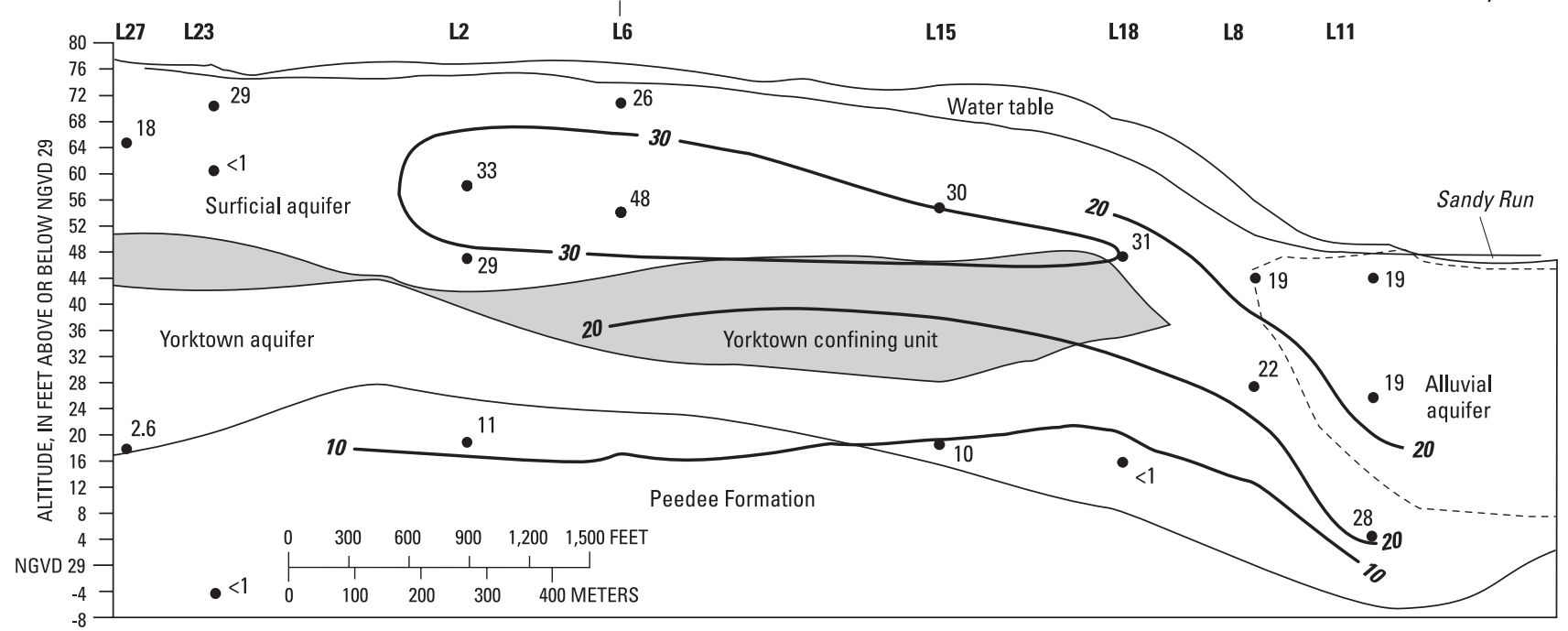

C. A

Upland wet flats

Well identifier Upland dry flats

Alluvial valley

$A^{\prime}$

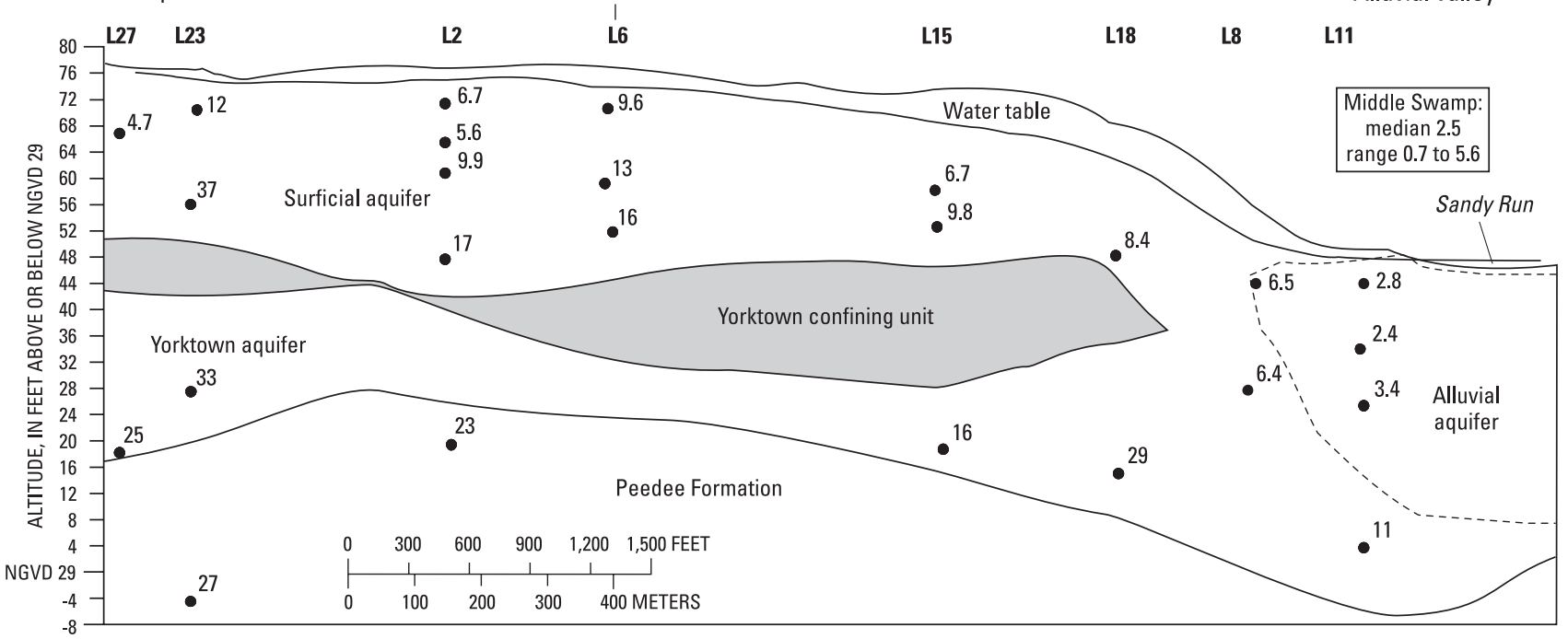

Figure 7. (A) Recharge dates and isopleths using chlorofluorocarbon concentrations, (B) isopleths and tritium concentrations, and (C) silica concentrations in ground water along transect $A-A^{\prime}$. 


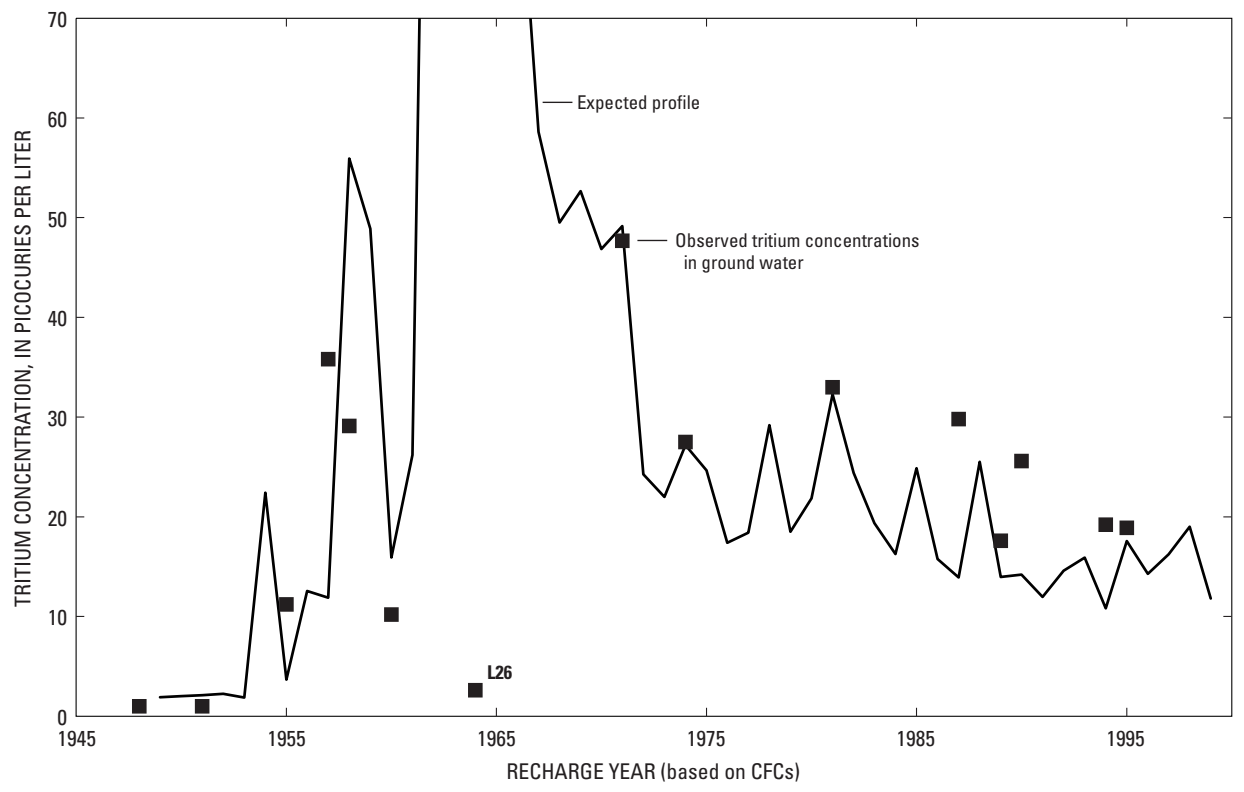

Figure 8. Tritium concentrations in ground-water samples plotted against recharge year. Recharge year was interpreted from chlorofluorocarbon (CFC) data. Low tritium concentration in sample L26 indicates recharge year calculated using CFCs is erroneous.

concentrations in the unconfined aquifers in this study area increase linearly as residence times increase $\left(\mathrm{R}^{2}=0.95\right.$, fig. 9).

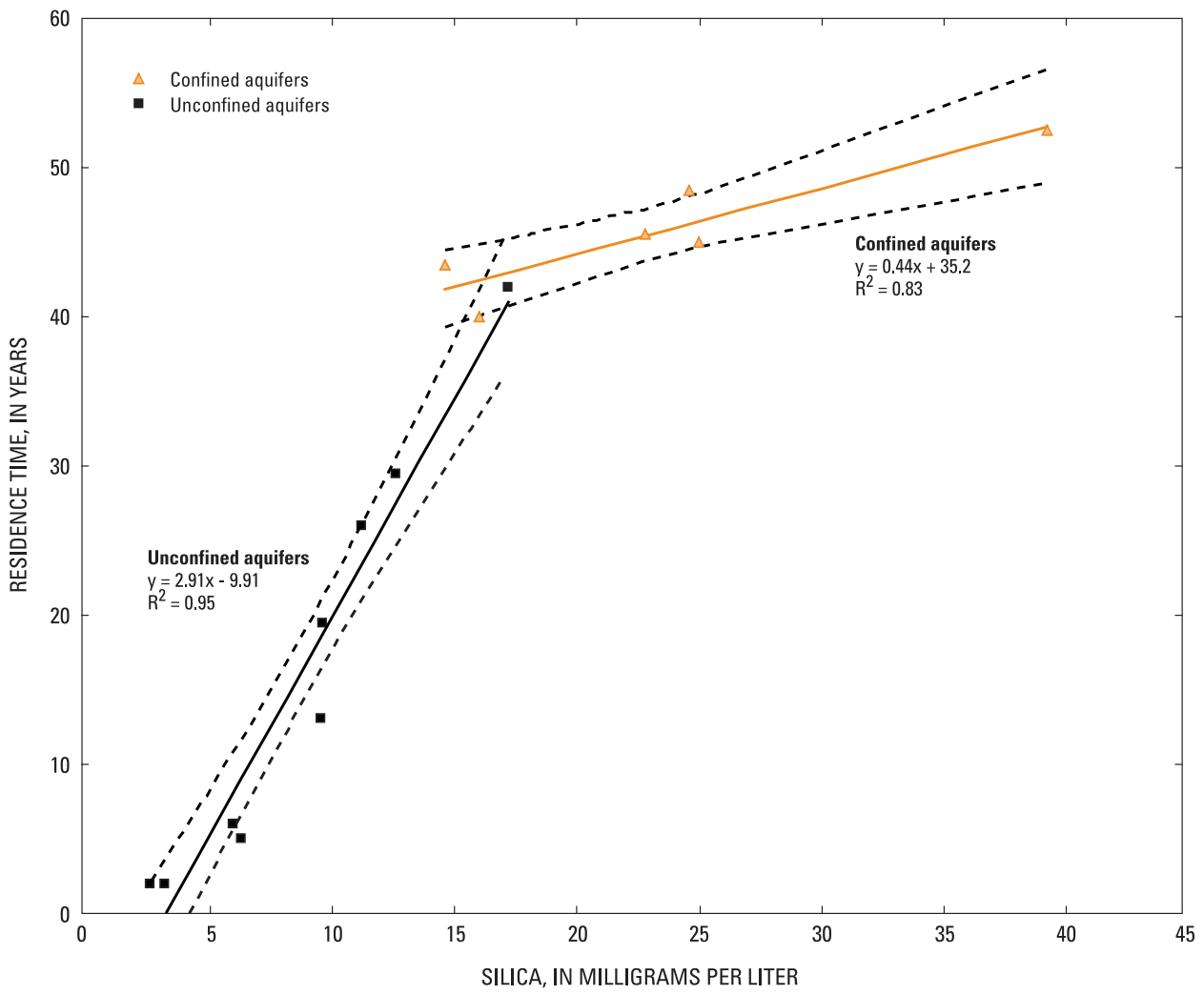

Figure 9. Ground-water residence time interpreted from chlorofluorocarbon (CFC) concentrations plotted against silica concentrations in samples from the Lizzie Research Station, North Carolina.
As a result, silica concentrations in the unconfined aquifer may be used as a first approximation of the residence time for samples for which direct estimates (CFCs, tritium) of residence times are not available. In the confined aquifers (primarily Yorktown), there also is a relation between silica concentrations and residence time; however, the slope indicates a faster rate of silica dissolution (fig. 9). In a later section of this report, the relation between silica and residence time is used to distinguish between the various sources of surface water, such as overland flow and shallow ground water.

Shallow ground water beneath the site often has concentrations of nitrate exceeding the drinking-water standard of 10 milligrams per liter $(\mathrm{mg} / \mathrm{L})$ as nitrogen. Nitrate concentrations decrease quickly with depth, with levels below $1 \mathrm{mg} / \mathrm{L}$ less than $15 \mathrm{ft}$ below the water table (fig. 10). Two processes may be responsible for the sharp decrease in nitrate with depth: (1) nitrate-contaminated water from agricultural activity may not have reached deeper portions of the flow system (in other words, the age of deep, lownitrate ground water pre-dates intensive fertilizer application) and(or) (2) nitrate is denitrified as it moves deeper in the aquifer system. Coupling age-dating and water-chemistry data can discern between these two processes.

Based on the dominant terminal electron acceptor, concentrations of redox-active constituents in ground water can be used to delineate the geochemical zones of an aquifer. Redox reactions occur in sequence, with the more thermodynamically favorable reactions occurring first (fig. 11). With respect to nitrate, denitrifying bacteria are facultative anaerobes and, as a result, prefer to use oxygen as an electron acceptor if it is present. Consequently, nitrate will not be denitrified in portions of the 


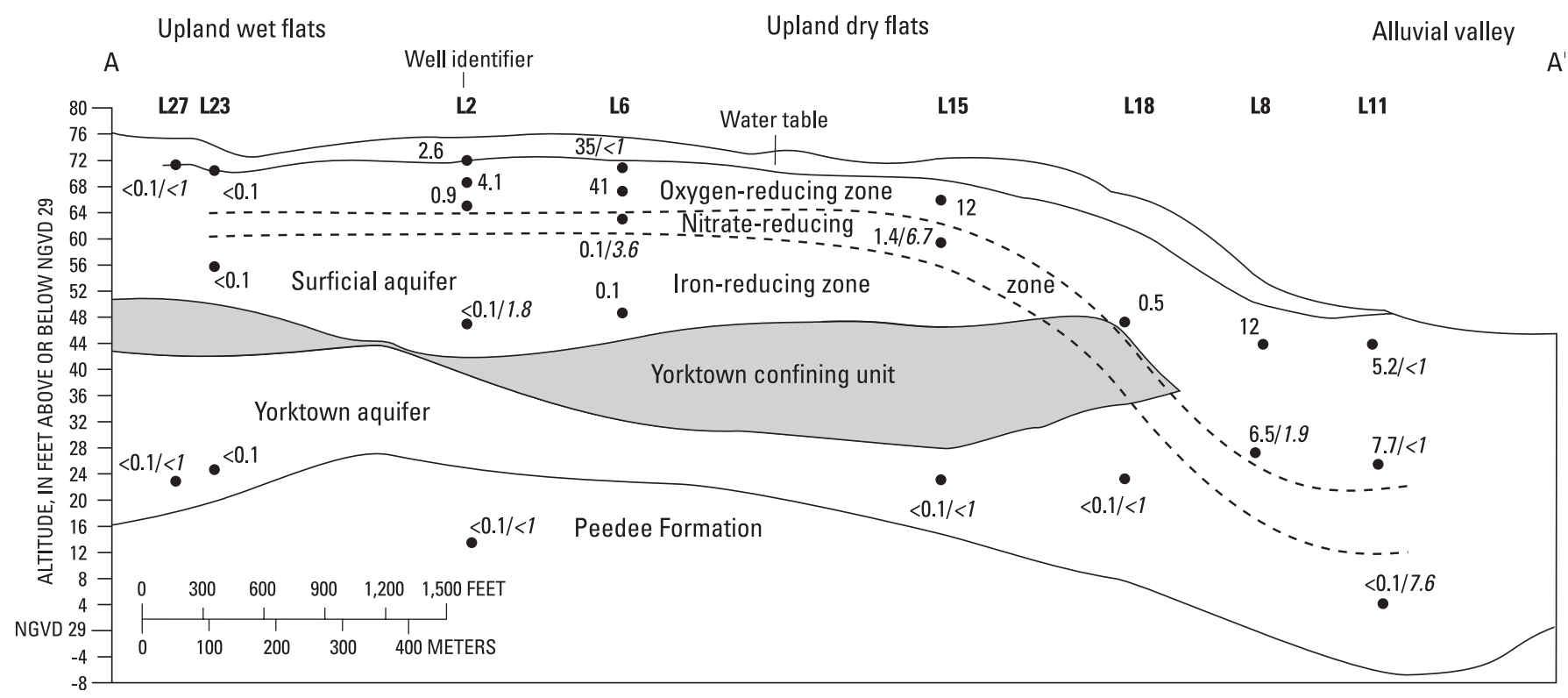

Figure 10. Delineation of terminal electron-accepting processes along transect $A-A^{\prime}$. Nitrate and excess nitrogen (italics) concentrations also are shown. (See figures 1 and 2 for well locations and line of section.)

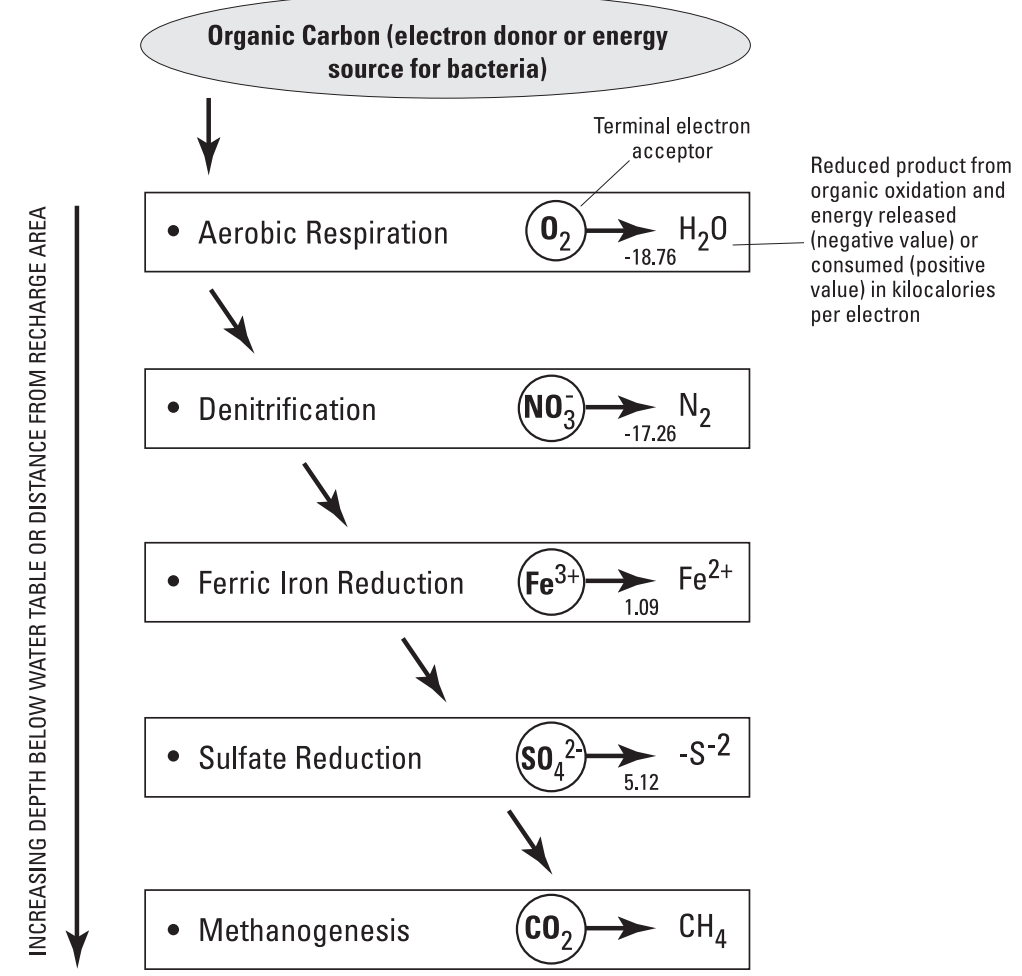

Figure 11. Sequence of oxidation-reduction reactions involved with oxidation of carbon (electron donor) and terminal electron acceptors preferred by bacteria in the saturated zone (modified from Korom, 1992). 
aquifer containing oxygen. Conversely, if high levels of dissolved iron are present, iron-reducing conditions are indicated and nitrate is not stable.

Dominant terminal electron acceptors (TEAPs) were delineated along flow paths through both the surficial and Yorktown aquifers in the study area to determine the portions of these aquifers where transformations of nitrate and other redoxactive contaminants may occur. Dominant TEAPs were determined by using the classification system of Chapelle and others (1995). Oxygen-reducing conditions were indicated when concentrations of dissolved oxygen (DO) exceeded $0.5 \mathrm{mg} / \mathrm{L}$. Nitrate-reducing conditions were considered dominant when DO levels were below $0.5 \mathrm{mg} / \mathrm{L}$ and nitrate concentrations were above $0.5 \mathrm{mg} / \mathrm{L}$. Iron-reducing conditions were considered dominant when both DO and nitrate levels were below $0.5 \mathrm{mg} / \mathrm{L}$ and iron concentrations exceeded $0.5 \mathrm{mg} / \mathrm{L}$. When seasonal variations in TEAPs occurred, the TEAP that was dominant for most of the year was selected.

Dominant TEAPs along a south to north transect across the study site indicate that only in the uppermost portions of the surficial aquifer ( $<16 \mathrm{ft}$ below the water table) is nitrate expected to be stable (fig. 10). Ground water becomes anaerobic at shallow depths (fig. 6), indicating that the consumption of oxygen by microbial respiration (fig. 11) quickly exceeds the supply. In deeper portions of the surficial aquifer and in most of the Yorktown aquifer iron-reducing conditions are present, and nitrate is not stable in this environment. Oxygen-reducing conditions occur at depth only at the northern terminus of the flow path where the confining unit is not present.

Selected ground-water samples were analyzed for dissolved nitrogen and argon gas to estimate the amount of nitrogen derived from atmospheric sources. Nitrogen and argon are incorporated in ground water during recharge by air-water equilibration processes. Air bubbles also can be transported to the saturated zone resulting in concentrations of nitrogen and argon in excess of equilibrium (Heaton and Vogel, 1981). Nitrogen gas that is derived from atmospheric sources (both airwater equilibrium and excess air) can be estimated by using nitrogen to argon ratios for samples from aerobic portions of the aquifer where denitrification is not expected (Dunkle and others, 1993). Aerobic samples have nitrogen to argon ratios that may suggest recharge water temperatures varying from 12 to 16 degrees Celsius $\left({ }^{\circ} \mathrm{C}\right.$; fig. 12$)$. A recharge temperature of $14{ }^{\circ} \mathrm{C}$ was used for the recharge temperature in calculations of excess nitrogen. The uncertainty in the recharge temperature $\left(14{ }^{\circ} \mathrm{C} \pm 2{ }^{\circ} \mathrm{C}\right)$ translates into $\pm 1 \mathrm{mg} / \mathrm{L}$ excess nitrogen.

As expected, aerobic samples plotted on or near the $14{ }^{\circ} \mathrm{C}$ air-saturated water with excess air (ASWEA) line, indicating that little, if any, denitrification has occurred in this portion of the aquifer (fig. 12). In contrast, most post-1953 (defined by detectable levels of tritium) anaerobic samples from the surficial aquifer and the unconfined portion of the Yorktown aquifer plot significantly to the right of the ASWEA line, indicating that varying amounts of denitrification has occurred in these portions of the aquifer. This indicates that the water samples contained elevated nitrate levels prior to entering an

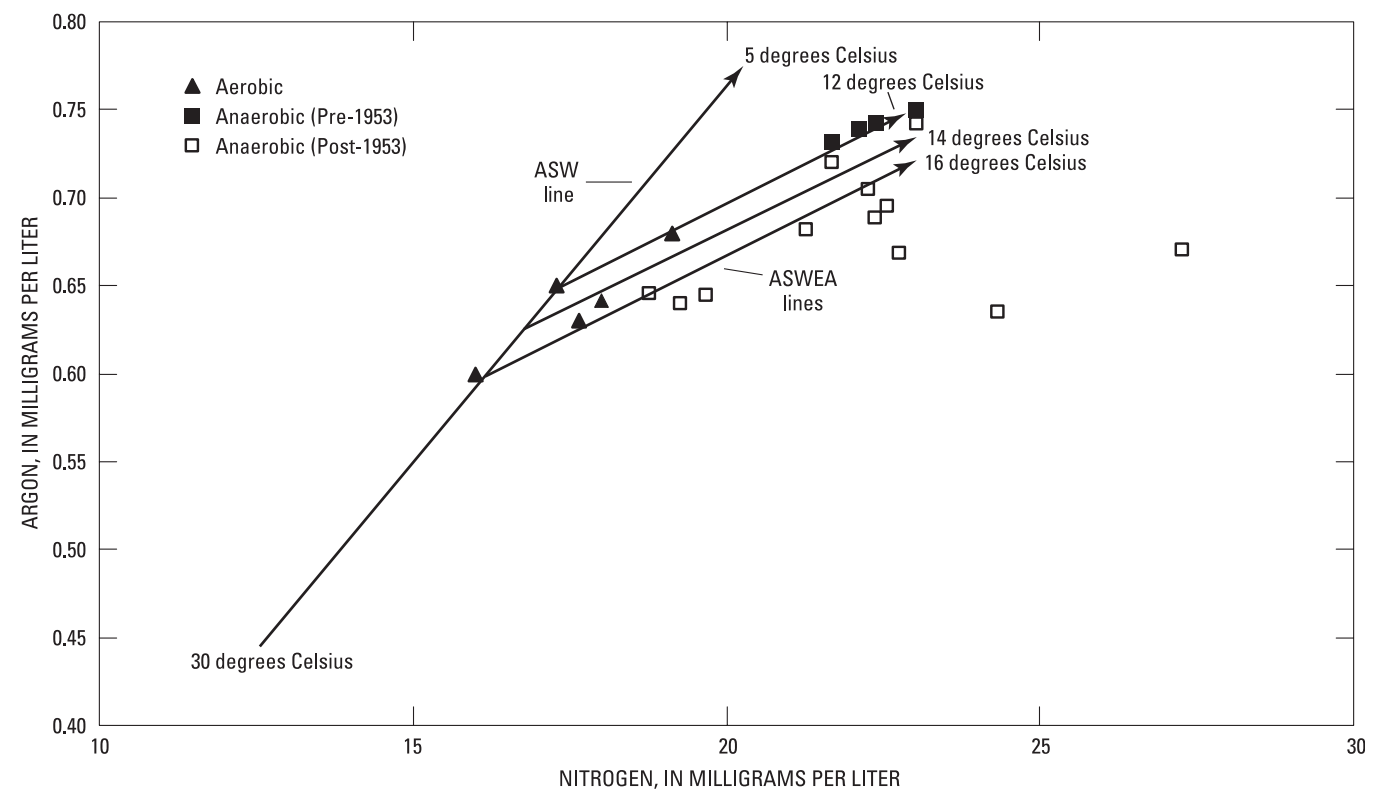

Figure 12. Dissolved argon and nitrogen concentrations in ground water. Air-saturated water (ASW) line depicts range of values expected for air-water at varying temperature. Air-saturated water with excess air (ASWEA) lines depict range of values for one recharge temperature but with varying amounts of excess air. Values to the right of the ASWEA line representing the recharge temperature for the sample indicate excess nitrogen from denitrification. 
anaerobic portion of the aquifer where the nitrate was subsequently denitrified. Pre-1953 samples were from the confined portion of the Yorktown aquifer. Although these samples also were anaerobic, they plotted on or near the $12{ }^{\circ} \mathrm{C}$ ASWEA line, which indicates that these samples had little or no excess nitrogen. Nitrogen applications to the land surface were lower prior to 1953 than more recently.

The combined use of age-dating, nitrate, excess nitrogen, and other redox-active constituents provides insight into the fate and history of nitrate contamination in the surficial and Yorktown aquifers (fig. 13). Three regimes regarding the history of nitrate contamination are apparent. Ground water that is less than 10 years old tends to be oxic and has elevated nitrate concentrations, reflecting both the stability of nitrate and a recharge time of high nitrogen applications. Ground water that is greater than 10 but less than 30 years old has low nitrate and DO concentrations, which indicate that nitrate is not stable, although the increased excess nitrogen values indicate that the water at one time contained elevated nitrate concentrations.

Ground water more than 30 years old also has low nitrate and DO concentrations and high levels of iron, indicating that nitrate also is not stable in this environment. However, these samples have little or no excess nitrogen, which suggests that the ground water did not contain elevated nitrate at an earlier point along the flow path.

\section{Ground-Water and Surface-Water Interactions: Nutrient Chemistry, Surface-Water Origin and Residence Time, and Pathways of Nutrients to Surface Water}

In Plum Tree Branch, nitrate was the dominant form of inorganic nitrogen throughout most of the year (fig. 14B). Only during base-flow conditions in the summer was ammonium the dominant form of inorganic nitrogen, with dissolved phosphorus concentrations also peaking during base-flow conditions in both Plum Tree Branch and Middle Swamp (fig. 14). As such, the annual nitrogen flux was primarily dominated by nitrate transported during the non-summer months. Ammonium became the dominant form in the summers of 2000 and 2002 likely because flows and nitrate inputs were reduced because of high levels of evapotranspiration, resulting in generally reducing conditions in Plum Tree Branch and Middle Swamp during low-flow periods. The mineralization of organic matter (eq. 1) then becomes the primary source of inorganic nitrogen and probably phosphorus as well, although release of phosphorus sorbed on sediment is also a possible mechanism (Spruill, 2000). Conversion to nitrate by nitrification (eq. 2) does not occur to a large degree because of the typically low dissolved-oxygen (DO) concentrations during

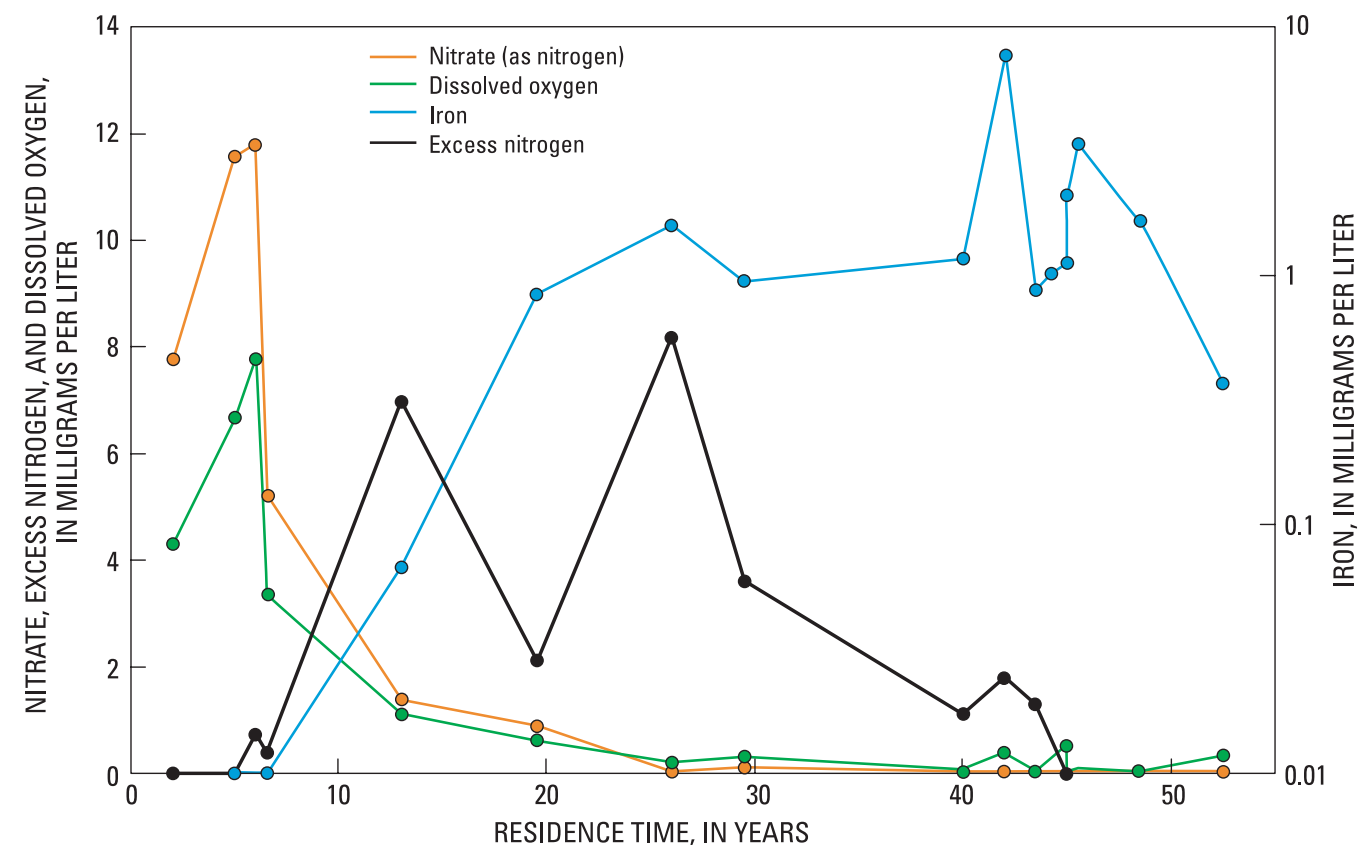

Figure 13. Redox-active species as a function of ground-water residence time. 

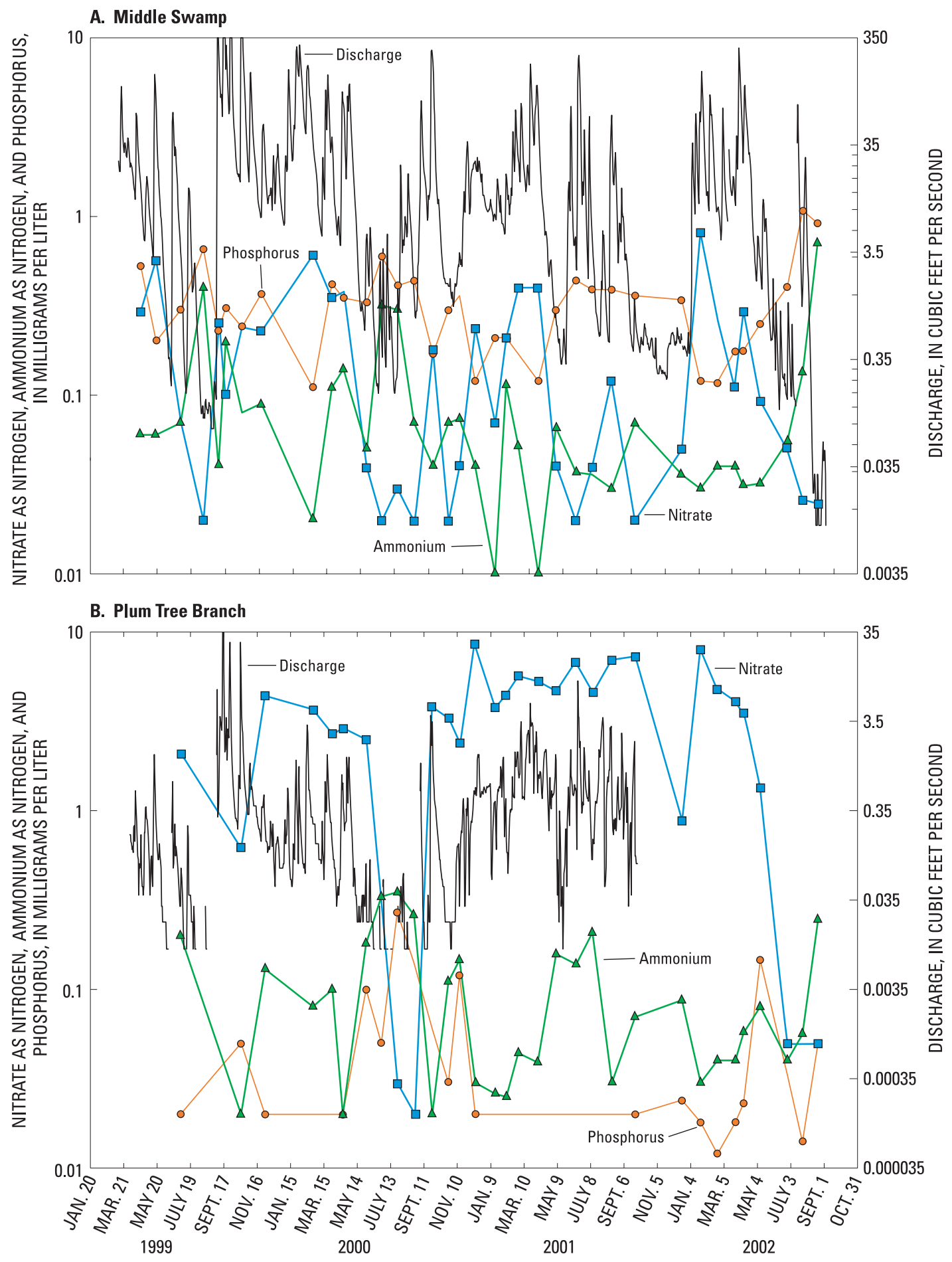

Figure 14. Nitrate and ammonium concentrations, phosphorus, and discharge for (A) Middle Swamp and (B) Plum Tree Branch. 
the summer (table 5). Low DO levels facilitate removal of nitrate by denitrification (eq. 3) from Plum Tree Branch and Middle Swamp and release phosphorus during low-flow periods. The summer of 2001 was wetter than the summers of 2000 and 2002, so the nitrate (and oxygen) fluxes from ground water were sufficient to maintain high nitrate concentrations and aerobic conditions.

$$
\begin{gathered}
\mathrm{C}_{106} \mathrm{H}_{263} \mathrm{O}_{110} \mathrm{~N}_{16} \mathrm{P}+107 \mathrm{O}_{2}+14 \mathrm{H}^{+} \rightarrow 106 \mathrm{CO}_{2} \\
+16 \mathrm{NH}^{+}+\mathrm{HPO}_{4}^{2-}+108 \mathrm{H}_{2} \mathrm{O} \\
\mathrm{NH}_{4}^{+}+2 \mathrm{O}_{2} \rightarrow \mathrm{NO}_{3}^{-}+2 \mathrm{H}^{+}+\mathrm{H}_{2} \mathrm{O} \\
5 \mathrm{CH}_{2} \mathrm{O}+4 \mathrm{NO}_{3}^{-}+4 \mathrm{H}^{+} \rightarrow 5 \mathrm{CO}_{2}+2 \mathrm{~N}_{2}+7 \mathrm{H}_{2} \mathrm{O}
\end{gathered}
$$

Inorganic nitrogen concentrations were much lower in both Sandy Run and Middle Swamp than in Plum Tree Branch, whereas dissolved phosphorus concentrations were about 3-5 times higher (fig. 14; table 2). With respect to nitrogen, this may reflect more efficient nitrogen processing (reduction by nitrogen loss to the atmosphere) in the riparian and hyporheic zones and the wider riparian forests in the larger basins. For phosphorus, which cannot be biologically converted and removed from the stream to the atmosphere, these data indicate that the higher-order streams accumulate phosphorus from eroded sediment, organic debris, and possibly point sources, which provide long-term sources of phosphorus and which can then be moved to points downstream in a natural fluvial system only by erosion or, temporarily, by biological uptake. Similar seasonal trends in nitrate, phosphorus, and DO were observed in all three watersheds, with significant decreases during the summer. Low DO and nitrate, associated with reducing conditions in the stream, indicate that denitrification during the summer base-flow periods may be responsible for much of the decline in nitrate and for increased dissolved phosphorus concentrations.

By comparing the major ion chemistry of the aquifers and streams, it is possible to discern the origin of surface waters. Ground water from the Yorktown aquifer was dominated by calcium $\left(\mathrm{Ca}^{2+}\right)$ and bicarbonate $\left(\mathrm{HCO}_{3}{ }^{-}\right.$, fig. 15$)$. In contrast, water from the surficial and alluvial aquifers had a more varied mix of cations and anions and was dominated by chloride $\left(\mathrm{Cl}^{-}\right)$ and nitrate $\left(\mathrm{NO}_{3}^{-}\right)$. Water from the alluvial aquifer had anion and cation chemistry that resembled the chemistry of the surficial aquifer but not that of the Yorktown aquifer. However, sodium to potassium ratios and other indicators suggest that the surficial and alluvial aquifers may have different sources of ions. The cation chemistry of Plum Tree Branch, Sandy Run, and Middle Swamp was bounded by the range in cation chemistry found in the surficial and alluvial aquifers (fig. 15). In contrast, the anion chemistry of all three streams, but particularly Sandy Run and Middle Swamp, trended from $\mathrm{Cl}^{-}$to $\mathrm{NO}_{3}{ }^{-}$-dominated water, similar to that of the surficial aquifer, to $\mathrm{HCO}_{3}{ }^{-}$-dominated water, similar to that of the Yorktown aquifer (fig. 15). Bicarbonate, however, is not conservative and may be generated by biologically mediated reactions occurring in the stream. Thus, the primary sources of ions in these streams are likely the surficial and alluvial aquifers. As will be discussed below, $\mathrm{SiO}_{2}$ concentrations in these streams were much lower than in the Yorktown aquifer, suggesting that little of the streamwater is derived from this aquifer.

Inferences about the watershed residence times of surface water can be made by comparing $\mathrm{SiO}_{2}$ concentrations in surface water to the relation between $\mathrm{SiO}_{2}$ and ground-water residence time. Flow paths in a watershed range from short overland flow paths on the order of hours to long ground-water flow paths on the order of years. Because these pathways often have distinctly different $\mathrm{SiO}_{2}$ concentrations, $\mathrm{SiO}_{2}$ often is used as a chemical tracer (for example, Scanlon and others, 2001). The availability of $\mathrm{SiO}_{2}$ and age-dating information provides an opportunity to determine the relation between $\mathrm{SiO}_{2}$ concentrations and residence time.

At the Lizzie site, concentrations of $\mathrm{SiO}_{2}$ increased as a function of ground-water age, with the shallowest parts of the surficial aquifer having the lowest $\mathrm{SiO}_{2}$ levels and the confined parts of the Yorktown having the highest levels (fig. 7). Inferences about the residence times of surface water in the watershed can be made by comparing $\mathrm{SiO}_{2}$ concentrations in surface water to the relation between $\mathrm{SiO}_{2}$ and ground-water residence time (fig. 9). The usefulness of $\mathrm{SiO}_{2}$ concentrations as indicators of both the source and residence times of streamflow is limited by the effect that biological activity has on $\mathrm{SiO}_{2}$ concentrations in streams. A bloom dominated by diatoms is indicated by a decrease in $\mathrm{SiO}_{2}$ concentrations in Middle Swamp, Sandy Run, and Plum Tree Branch during late winter or early spring followed by a return to normal levels. This pattern has been observed in streams elsewhere and has been attributed to a spring diatom bloom followed by summer blooms with a mixed phytoplankton population. As a result, some of the lowest $\mathrm{SiO}_{2}$ concentrations (for example, bottom quartile) observed in Middle Swamp, Sandy Run, and Plum Tree Branch may not be reliable indicators of watershed residence time.

Concentrations of $\mathrm{SiO}_{2}$ in Plum Tree Branch were always in the range indicated by the surficial aquifer (fig. 16). This indicates that water in Plum Tree Branch during base flow is derived largely from the surficial aquifer, having a watershed residence time of 15 years or less. Little or no contribution from the Yorktown aquifer is expected since this stream does not breach the confining unit separating the surficial aquifer from the Yorktown. Overland flow and other fast pathways having low $\mathrm{SiO}_{2}$ concentrations due to low contact time with sediments are not indicated as major sources in Plum Tree Branch during base flow. In contrast to Plum Tree Branch, Middle Swamp and Sandy Run occasionally incise through the confining unit and into the Yorktown, so some Yorktown discharge into these streams is more likely. However, $\mathrm{SiO}_{2}$ concentrations in Middle Swamp and Plum Tree Branch are not intermediate between unconfined and confined aquifers. In fact, $\mathrm{SiO}_{2}$ concentrations are much lower than those found in the unconfined aquifers, indicating that a large portion of flow in these streams has a 
Table 5. Seasonal and annual loads and annual yields of total nitrogen and phosphorus at 14 stations in the Neuse River basin, North Carolina.

[USGS, U.S. Geological Survey; tons $/ \mathrm{mi}^{2}$, tons per square mile]

\begin{tabular}{|c|c|c|c|c|c|c|c|}
\hline \multirow{2}{*}{ Station name } & \multirow{2}{*}{$\begin{array}{c}\text { USGS station } \\
\text { number }\end{array}$} & \multicolumn{4}{|c|}{ Seasonal total nitrogen load (tons) } & \multirow{2}{*}{$\begin{array}{l}\text { Annual total } \\
\text { nitrogen } \\
\text { load } \\
\text { (tons) }\end{array}$} & \multirow{2}{*}{$\begin{array}{c}\text { Annual total } \\
\text { nitrogen yield } \\
\text { (tons } / \mathrm{mi}^{2} \text { ) }\end{array}$} \\
\hline & & Winter & Spring & Summer & Fall & & \\
\hline \multicolumn{8}{|c|}{ Calendar year 2000} \\
\hline Bear Creek at Mays Store & 208925200 & 98 & 36 & 42 & 24 & 201 & 3.4 \\
\hline Neuse River at Kinston & 2089500 & 1,427 & 621 & 774 & 446 & 3,268 & 1.2 \\
\hline Sandy Run near Lizzie & 209173200 & 16 & 3.8 & 6.0 & .76 & 27 & .86 \\
\hline Middle Swamp near Farmville & 2091736 & 23 & 5.4 & 6.8 & 3.0 & 38 & .74 \\
\hline Little Contentnea near Willow Green & 2091737 & 56 & 15 & 19 & 6.3 & 97 & .63 \\
\hline Little Contentnea at Scuffleton & 2091740 & 82 & 29 & 37 & 13 & 160 & .93 \\
\hline Contentenea Creek near Lucama & 2090380 & 59 & 16 & 50 & 13 & 139 & .87 \\
\hline Neuse River near Fort Barnwell & 2091814 & 1,778 & 774 & 1,023 & 618 & 4,192 & 1.2 \\
\hline Trent River near Trenton & 2092500 & 75 & 30 & 82 & 20 & 207 & 1.2 \\
\hline Swift Creek near Steets Ferry & 209205053 & 171 & 69 & 145 & 22 & 408 & 1.5 \\
\hline \multicolumn{8}{|c|}{ Calendar year 2001} \\
\hline Bear Creek at Mays Store & 208925200 & 50 & 44 & 40 & 16 & 150 & 2.6 \\
\hline Neuse River at Kinston & 2089500 & 579 & 791 & 480 & 177 & 2,027 & .75 \\
\hline Sandy Run near Lizzie & 209173200 & 4.1 & 5.2 & 1.1 & .18 & 11 & .34 \\
\hline Middle Swamp near Farmville & 2091736 & 7.8 & 7.4 & 2.2 & .01 & 17 & .34 \\
\hline Little Contentnea near Willow Green & 2091737 & 15 & 25 & 10 & 1.1 & 51 & .33 \\
\hline Little Contentnea at Scuffleton & 2091740 & 30 & 45 & 24 & 3.8 & 102 & .59 \\
\hline
\end{tabular}


Table 5. Seasonal and annual loads and annual yields of total nitrogen and phosphorus at 14 stations in the Neuse River basin, North Carolina.-Continued

[USGS, U.S. Geological Survey; tons $/ \mathrm{mi}^{2}$, tons per square mile]

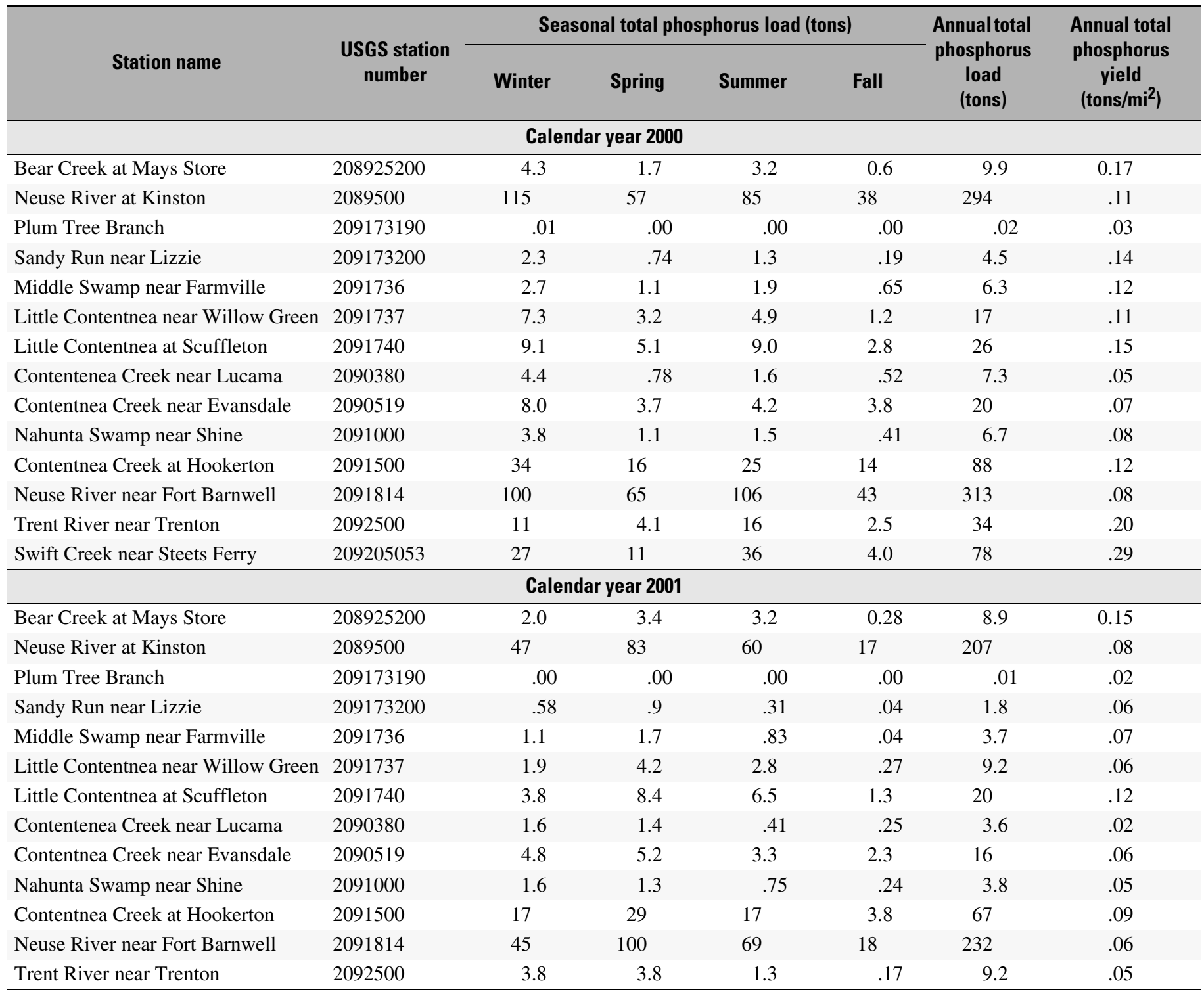




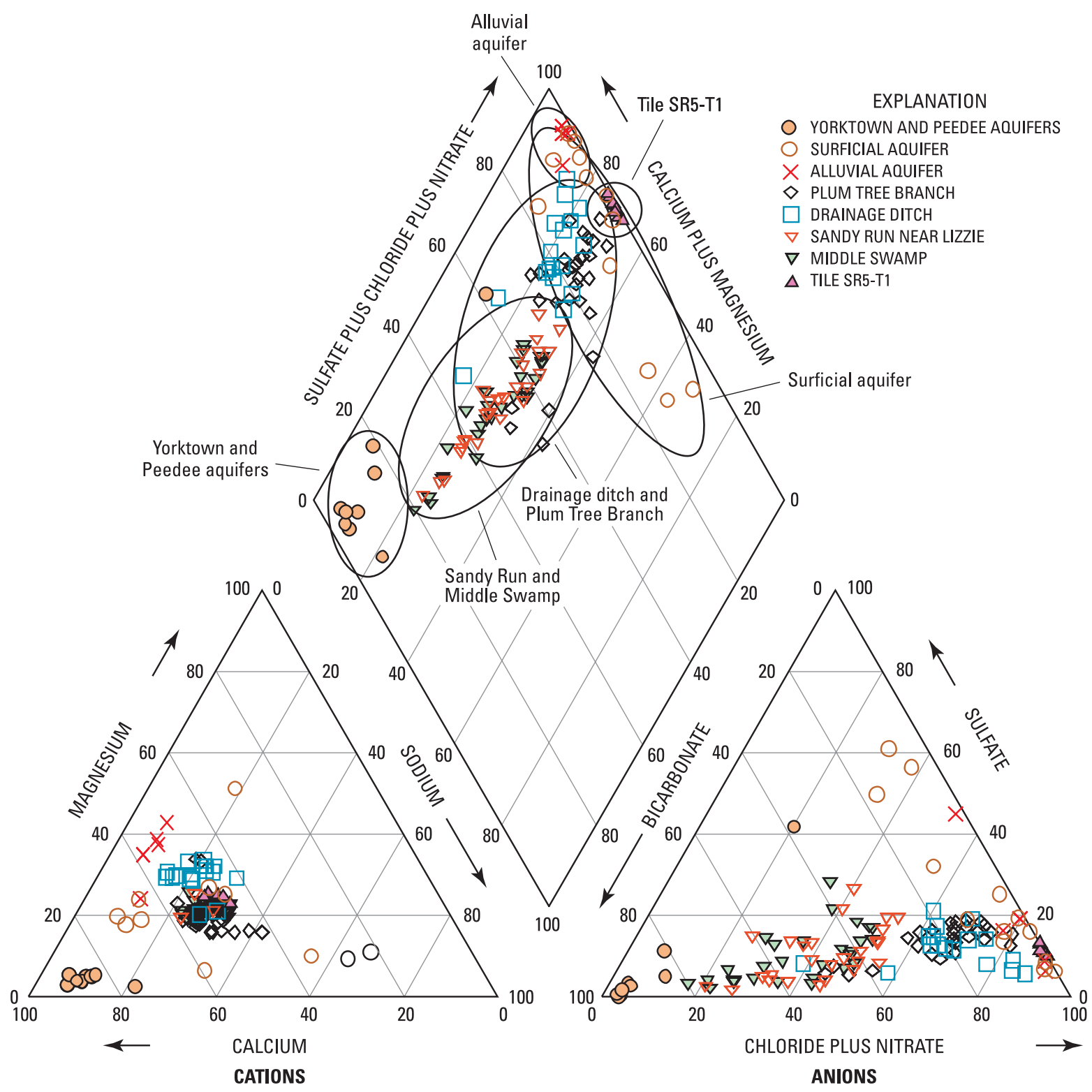

Figure 15. Trilinear diagrams of water chemistry in ground water, streams, and artificial drainages at the Lizzie Research Station, North Carolina. Unconfined aquifer data include both the surficial aquifer and the alluvial aquifer. Confined aquifer data include confined portions of the Yorktown aquifer and Peedee Formation. 


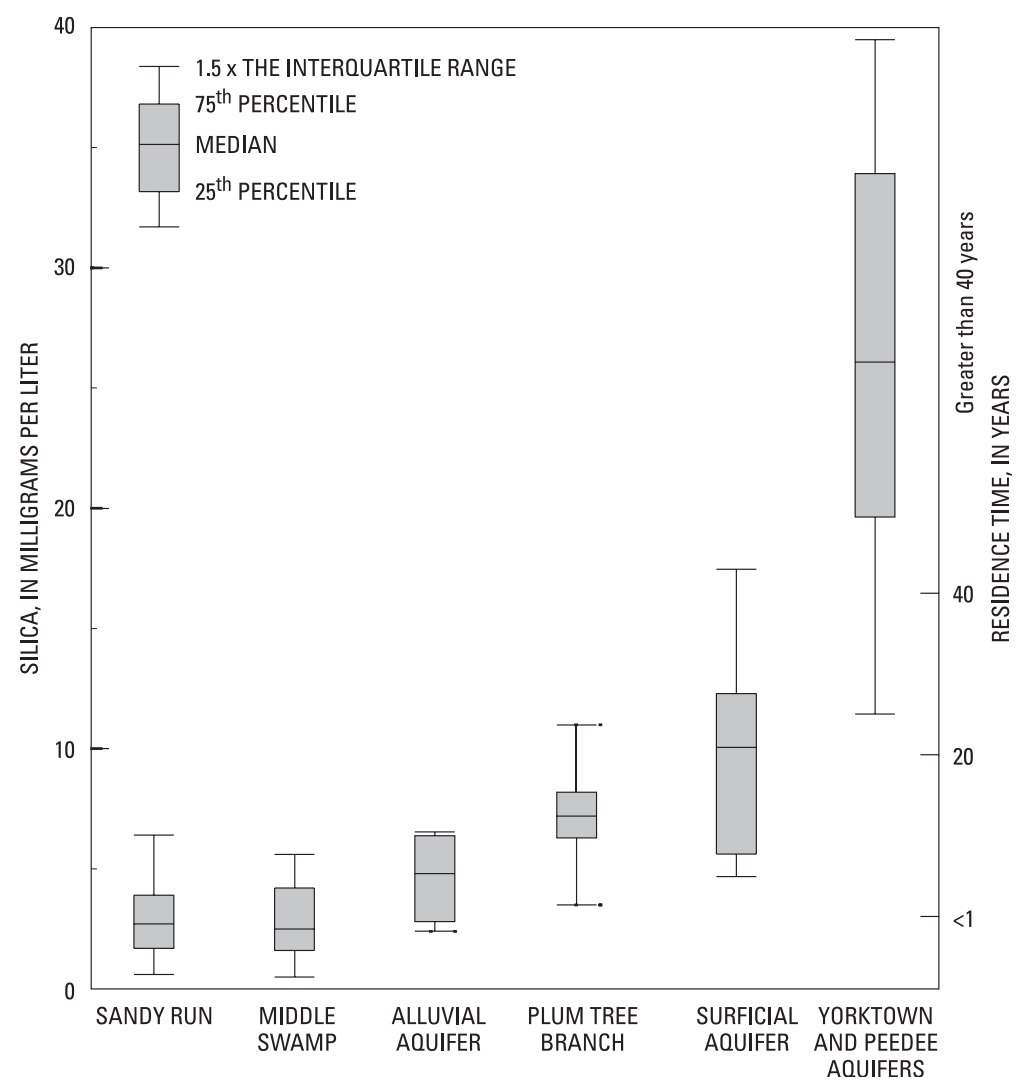

Figure 16. Concentrations of silica in ground- and surface-water samples collected at the Lizzie Research Station, North Carolina.

short residence time (for example, $<3$ years) and is likely derived from overland flow, discharge of young water from recharge into near-stream alluvial deposits, and the discharge of young water from bank storage after flood events. Thus, the alluvial and terrace deposits in second- and higher-order streams act as both recharge and discharge areas, depending on prevailing hydrologic conditions, discharging to streams during dry periods and recharging during wet periods.

High nitrate concentrations in the surficial aquifer (median nitrate concentration of $6.4 \mathrm{mg} / \mathrm{L}$ excluding wells in the pocosin) are the likely source of nitrate in Plum Tree Branch (median nitrate concentration of $3.6 \mathrm{mg} / \mathrm{L}$ ). The two transport mechanisms considered for the elevated nitrate concentrations in Plum Tree Branch were direct discharge of nitrate in ground water to surface water and tile-drain discharge from site SR5-

T1 (fig. 2). Overland runoff from stormflow was not considered in this study because individual storm events were not monitored and only moderate- to low-flow conditions are represented. Ground- and surface-water samples were collected along a transect extending from site L2 to site FP (fig. 2) and analyzed for nutrients and redox-active constituents to assess the likelihood of direct discharge of nitrogen to Plum Tree Branch.

High DO concentrations indicate that aerobic conditions exist upgradient from the riparian zone with high concentrations of nitrate found beneath the spray field (fig. 17). As ground water enters the subsurface riparian zone, DO and nitrate concentrations are very low, and iron and methane concentrations increase, indicating that conditions are sufficiently reducing to assure that nitrate passing through this zone is likely to be denitrified (eq. 3) prior to discharging to Plum Tree Branch. Dilution of aerobic, nitrate-laden, shallow ground water with a large fraction of deeper anaerobic water can yield similar riparian zone concentrations of redox-active constituents to those found near Plum Tree Branch. However, $\mathrm{SiO}_{2}$ concentrations remained essentially constant along the transect, indicating that the same portion of the ground-water system was being sampled (fig. 17). As such, denitrification is the likely nitrate removal mechanism in the riparian zone. Unfortunately, dissolved gas samples collected in the riparian zone and in the streambed contained too much methane and carbon dioxide to obtain a meaningful estimate of excess nitrogen.

Increases in ammonium levels occurred (0.22 to $4.3 \mathrm{mg} / \mathrm{L}$, table 3 ) in the riparian zone. Although dissimilatory nitrate reduction to ammonium (DNRA) may be responsible for a small amount of nitrate reduction, mineralization of organic matter (eq. 1) is considered the more likely process for ammonium generation in riparian zones (Duff and Triska, 2000). Denitrification, DNRA, and plant uptake are possible pathways for nitrate removal. Increase in ammonium levels occurring in the riparian zone are very small relative to upgradient nitrate concentrations, indicating that DNRA may be responsible for only a small fraction of nitrate reduction. Consequently, plant uptake and(or) denitrification are the likely nitrate-removal mechanisms in the riparian zone. Mineralization of organic matter also appears to be a likely mechanism for high concentrations of phosphorus (>0.5 mg/L) occurring in stream and riparian zone wells sampled along Sandy Run (table 3).

Ground water that is intercepted by the tile drain in the spray field is routed directly to Plum Tree Branch (fig. 2); as a result, riparian zone processes that lower nitrate fluxes are bypassed. The nitrate flux from the tile drain remained fairly constant throughout the year (fig. 18) and can account for approximately 30 percent of the increase in nitrate flux along the reach from S7 to S2 (fig. 2) based on instantaneous measurements. Nitrate flux from the tile drain decreased to about 15 percent of the total increase in nitrate flux during periods of high discharge (fig. 18). Overland flow and, perhaps, direct ground-water discharge that pass through the riparian zone too quickly to be denitrified are possible sources of increased nitrate flux during high-discharge periods.

Dissolved inorganic nitrogen (DIN) concentrations are much lower in both Sandy Run (mean DIN $=0.3 \mathrm{mg} / \mathrm{L}$ ) and Middle Swamp ( $0.3 \mathrm{mg} / \mathrm{L})$ than in Plum Tree Branch $(5.4 \mathrm{mg} / \mathrm{L})$. This may reflect more efficient nitrogen processing in the riparian zone and(or) greater separation of agricultural land from streams in these larger basins because of wider riparian buffer zones. Strongly reducing conditions are present 


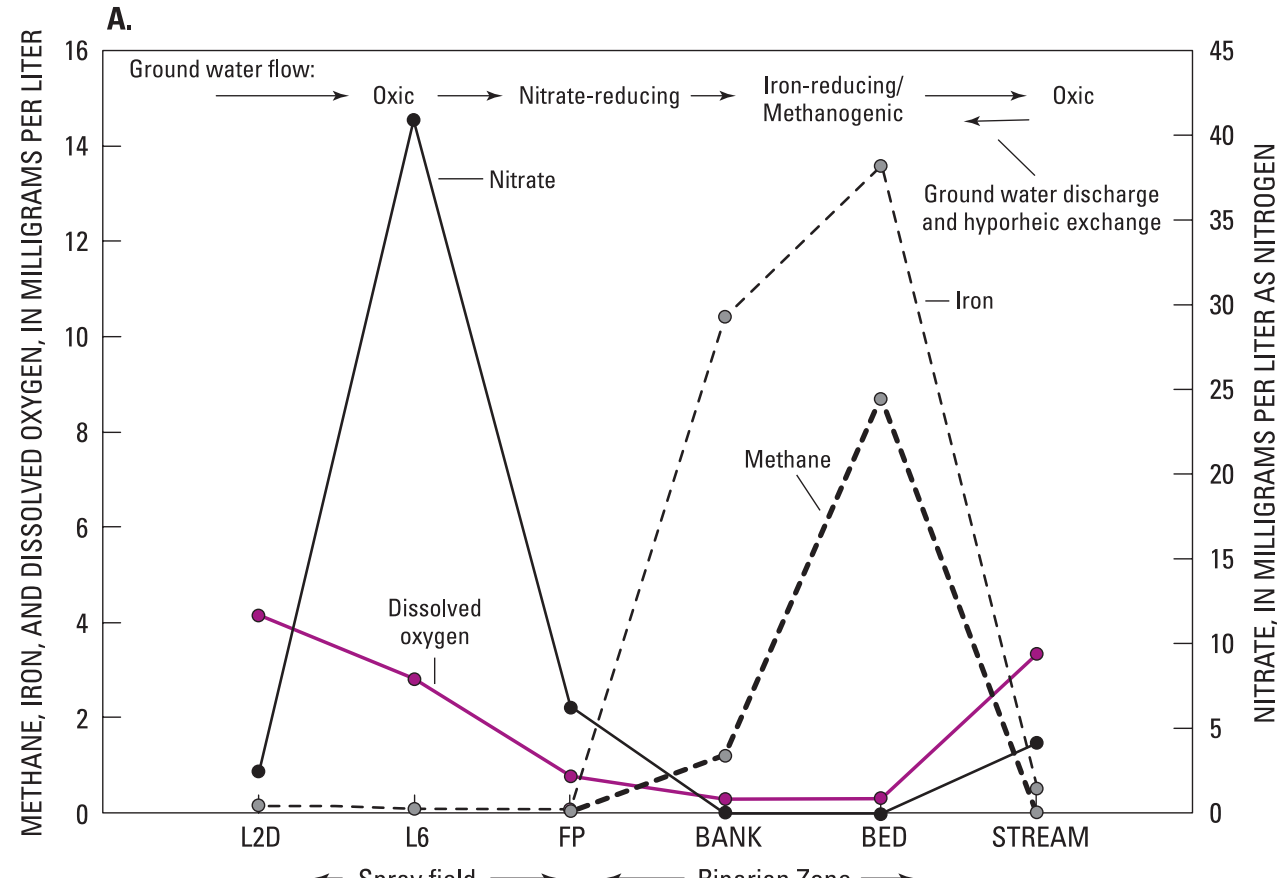

B.

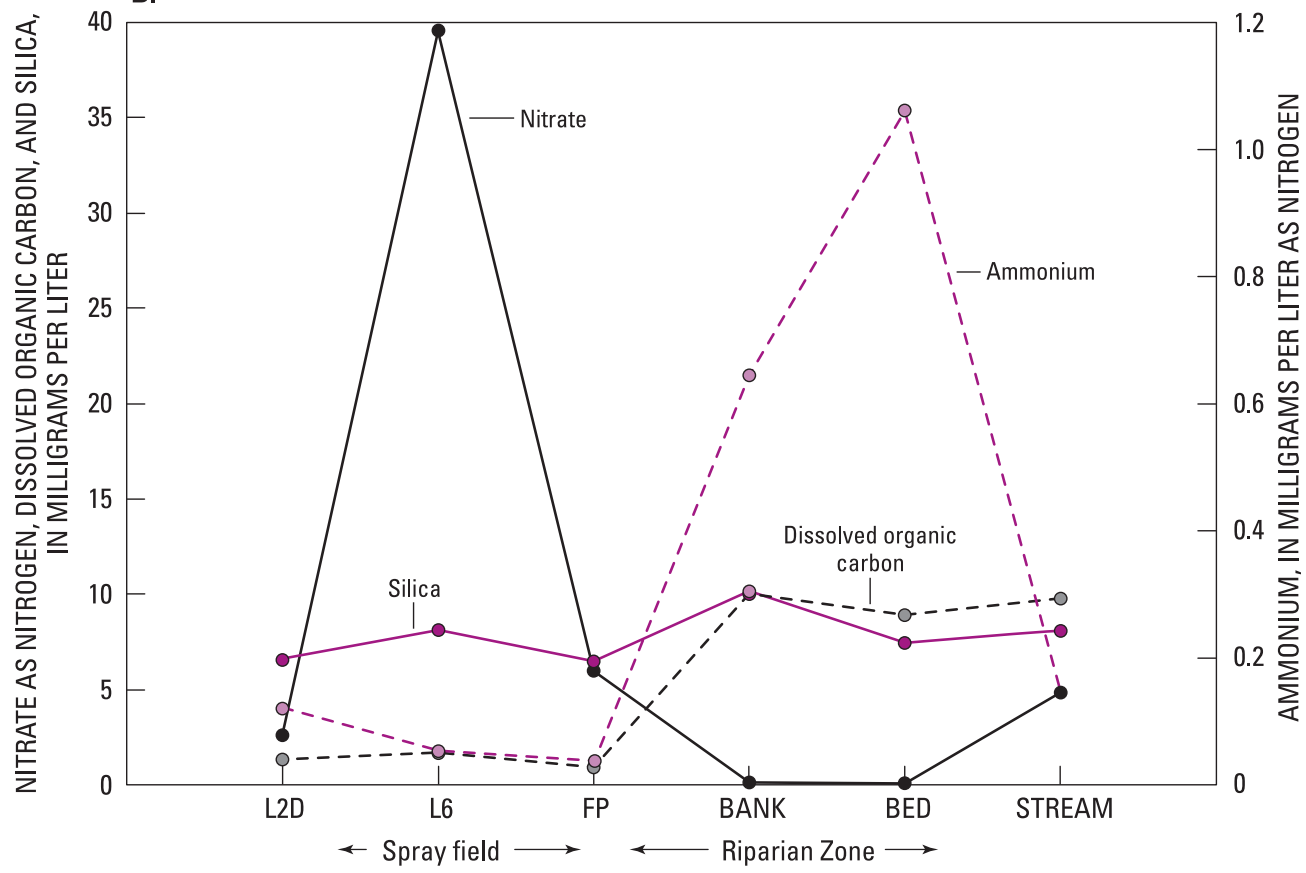

Figure 17. Terminal electron-accepting zones along transect $\mathrm{L} 2 \mathrm{to}$ Plum Tree Branch near site FP and concentrations of (A) methane, iron, dissolved oxygen, and nitrate; and (B) silica, dissolved organic carbon, nitrate, and ammonium. 


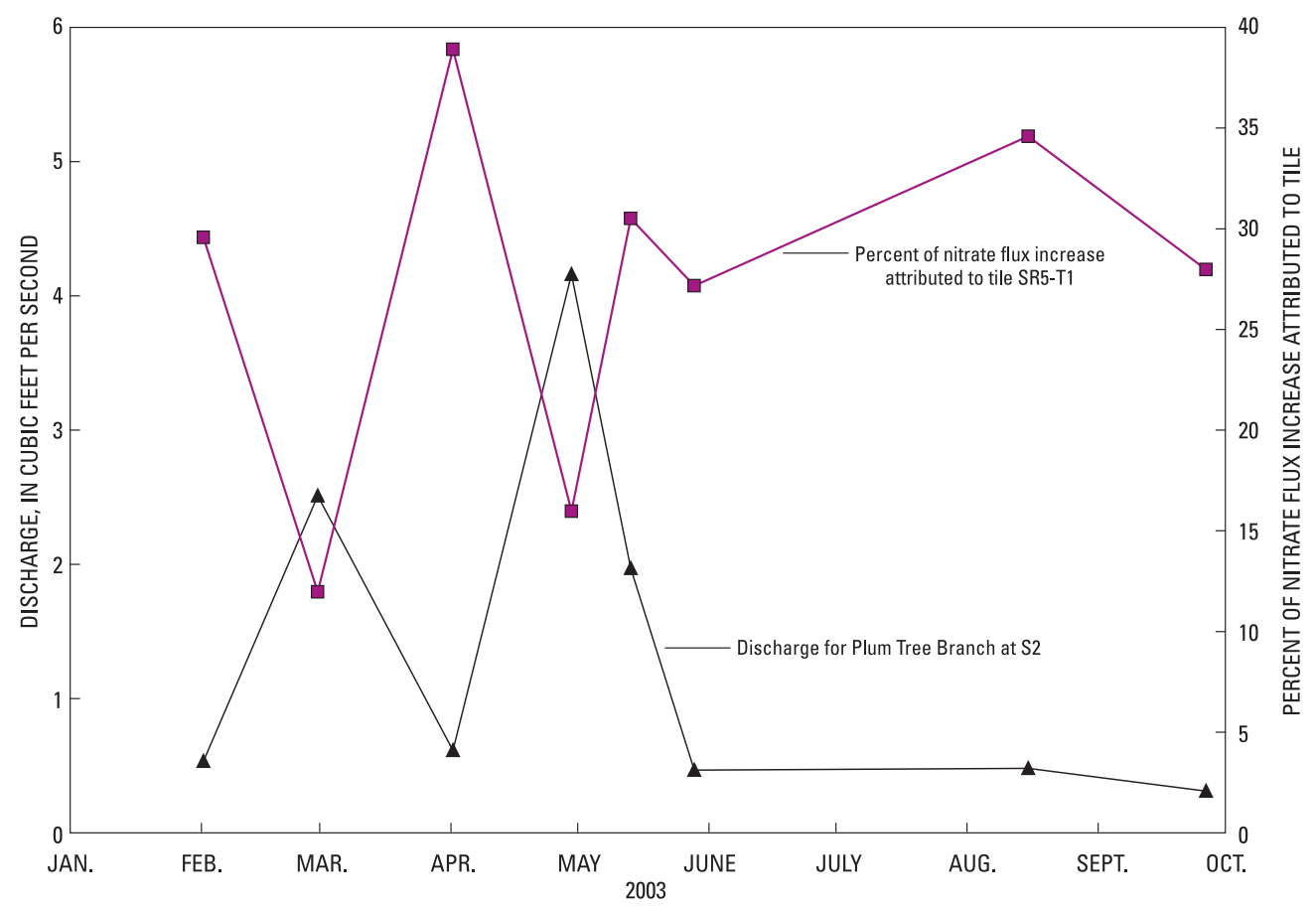

Figure 18. Percent of nitrate flux increase along Plum Tree Branch reach from S7 to S2 that is attributed to tile drain SR5-T1, and discharge at Plum Tree Branch at S2.

in the riparian zone and streambed of Sandy Run (table 3), indicating that direct discharge of nitrate to surface water during base-flow conditions is not likely in this drainage.

\section{Effects on Ground-Water Quality of Changing to Swine-Waste Fertilizer From Inorganic Fertilizer}

In addition to characterizing fate and transport of nitrogen in a coastal plain stream-aquifer system, the Lizzie Research site provided an excellent opportunity to evaluate the effects on ground-water and surface-water quality of using swine wastes for fertilizing crops, specifically nitrogen and phosphorus. The Lizzie Research site was included in a 1995 USGS NAWQA study as a secondary flow-path study site. (The primary flowpath site was in the Pete Mitchell Swamp watershed in the TarPamlico River basin [Spruill and others, 1998]). The objectives of the NAWQA flow-path studies were to evaluate chemical characteristics of ground water in a coastal plain aquifer and changes that occur in ground-water chemistry from recharge to discharge areas of the shallow aquifer at selected sites along a ground-water flow path. Five wells (L2, L4, L5, L6, and L16, fig. 2; see table 3 for locations) were selected from a set of more than 40 wells installed for a recharge study at the Lizzie Research site by the DWQ Groundwater Section. Well L2, located upgradient from cultivated fields, was selected by the
NAWQA study team to represent water quality least affected by intensive agricultural operations. Wells L6 and L5 were located in cultivated fields used for growing corn, soybeans, and wheat. Wells L4 and L16 were located at the field edge, downgradient from the fields where crops were grown.

The source of nitrogen fertilizer used at the study site changed in 1995. Prior to 1995, the primary nitrogen fertilizer used at the site was ammonium nitrate, applied at the rate of 100-200 lbs/acre as recommended for growing corn in North Carolina (North Carolina State University, 1992). The recommended rate for soybeans in the Coastal Plain at this time was 30-50 lbs/acre and for wheat, $80-100 \mathrm{lbs} / \mathrm{acre}$ (North Carolina State University, 1992). These recommended application rates remain essentially the same (North Carolina State University, 2003). Fertilizer is generally applied to corn and soybeans at least two times per growing season, first in March or April and again in June. Both crops are planted in the spring, and corn is harvested during late summer and soybeans are harvested in the fall. The fields then may be left fallow or planted in late fall in winter wheat. During the late spring of 1995, wastewater from a newly constructed lagoon was applied to fertilize crops on about 90 acres east and south of the lagoon (fig. 2). Other than this change in fertilizer type, other farming practices, recommended fertilization rates, general application times, and the crops planted remained the same.

Changes in the quality of shallow ground water beneath and downgradient from the spray fields were observed between 
1995 and 1999. Five wells (L2, L4, L5, L6, L16; fig. 2; table 3) at the Lizzie Research Station were sampled in March 1995 as part of the NAWQA secondary flow-path study for dissolved major ions, nutrients, selected pesticides, and organic carbon (Smith and others, 1996). Well L2 was located upgradient from cultivated fields and represented shallow ground water. Well L6 represented shallow ground-water quality beneath the cultivated field, which had been planted in corn the previous growing season. Well L4 also represented shallow ground-water downgradient from the cultivated fields. Wells L5 and L16 tapped the first confined aquifer (Yorktown aquifer) beneath the cultivated field and were used to evaluate whether water was moving from the shallow to the deep aquifer. Concentrations of selected constituents, including dissolved nitrate, calcium, magnesium, sodium, and potassium, in the 1995 ground-water samples from two of the wells, L2 (the upgradient well) and L6 (the field well), are shown in figure 19.

By 1999 when the MIMS project began, lagoon wastes had been applied to fields used for growing corn, wheat, and soybeans for approximately 4 years. Samples were collected in March 1999 from these same wells.

Concentrations of all constituents were approximately the same in 1999 in the upgradient well (L2), but

concentrations of all constituents except phosphorus increased in the field well (L6) and the downgradient well (L4) spraying). by a factor of 2 or greater. The nitrate concentration in well L6 increased from $10 \mathrm{mg} / \mathrm{L}$ in 1995 to $35 \mathrm{mg} / \mathrm{L}$ in 1999 . The ${ }^{15} \mathrm{~N}$ value of 21.8 in well L6, indicative of swine wastes (Karr and others, 2001; Spruill and others, 2002) was higher than the 8.7 per mil value of ${ }^{15} \mathrm{~N}$ in water from well L2. By 2002 , nitrate concentrations had remained relatively unchanged from 1995 in the upgradient well (L2), whereas nitrate concentrations had

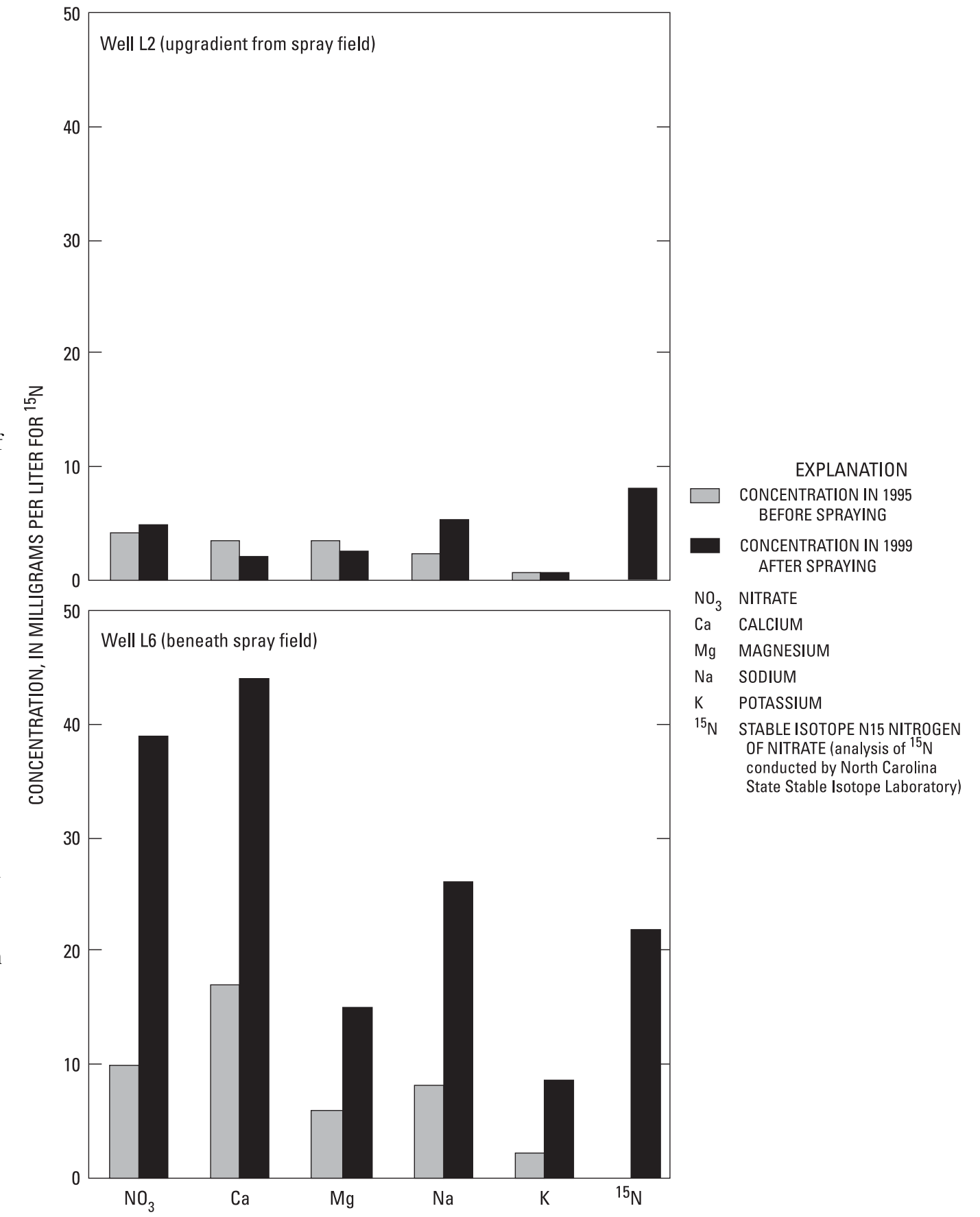

Figure 19. Chemical constituent concentrations in ground water from wells L2 and L6 at the Lizzie Research Station, North Carolina, for 1995 (before swine-waste spray was used) and 1999 (after 4 years of swine-waste 
varied between 2 and 5 times higher since 1999 in well L6 (fig. 20).

The use of sprayed swine wastes at this site resulted in increased concentrations of nitrate and other chemical constituents. No change in dissolved phosphorus concentrations was observed in the spray field well (L6, fig. 2), and no concentration exceeded $0.02 \mathrm{mg} / \mathrm{L}$, suggesting that phosphorus is adsorbed to the soil matrix before reaching shallow ground water. The nitrite-plus-nitrate concentration in ground water beneath the spray field (well L6, fig. 2) increased by a factor of 3.5 within 4 years of spray application-from 10 to $35 \mathrm{mg} / \mathrm{L}$, and a concentration as high as $56 \mathrm{mg} / \mathrm{L}$ was observed in this well in spring 2002 (fig. 20).

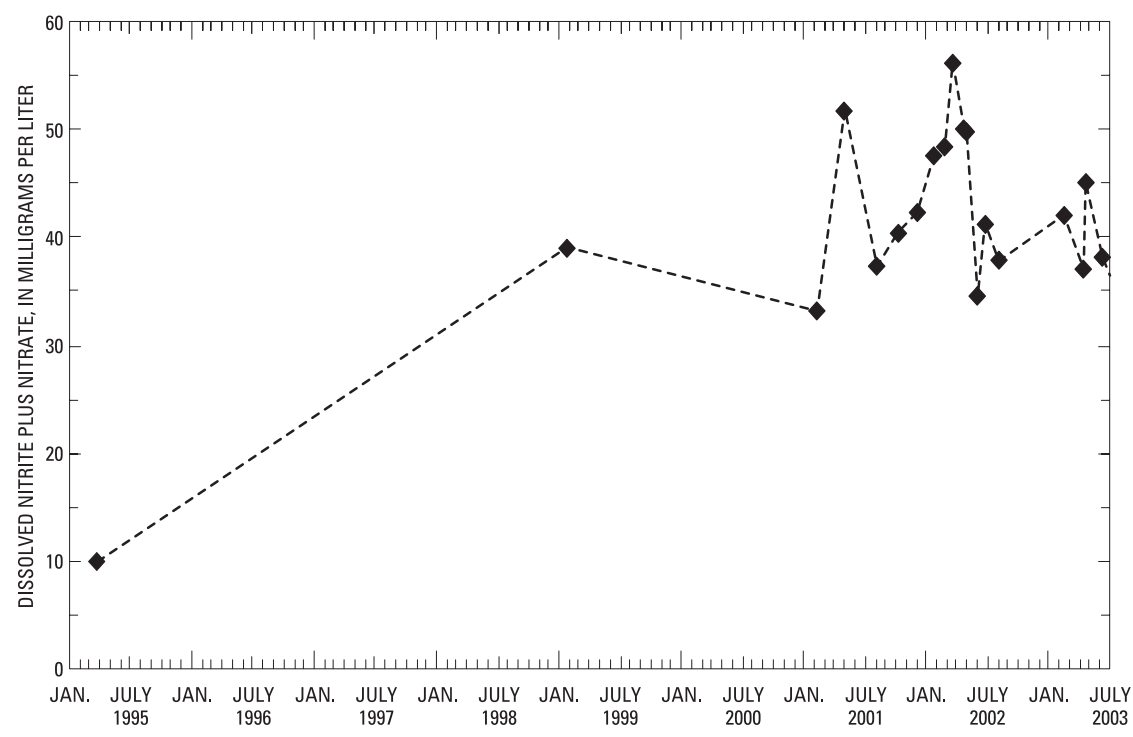

Figure 20. Nitrite-plus-nitrate concentrations in ground-water samples from well L6 at the Lizzie Research Station, North Carolina, 1995-2003.
Spruill, 2004), specifically in the Sandy Run and Middle Swamp area where the Lizzie Research Station is located, also indicate that nitrate concentrations in drainage tiles located in fields where swine wastes were sprayed on crops were significantly higher than in drainage tiles located in fields where commercial fertilizer was used (fig. 22).

Why are nitrate concentrations higher in both ground water and tile drainage from fields fertilized with sprayed swine wastes than in ground water and tile drainage from fields fertilized with commercial fertilizer? Results of previous studies indicate that increasing nitrogen fertilizer rates generally result in higher nitrateconcentrations and offsite transport in subsurface tile drainage, regardless of the nitrogen source (Baker and Johnson, 1981; Evans and others, 1984; Randall and others, 2000; Jaynes and others, 2001). Results of these studies were based on applications of conventional fertilizers (urea, anhyrdous ammonia) and(or) animal wastes (swine-lagoon effluent and dairy manure). Randall and others (2000) applied dairy manure and urea at equivalent rates of available nitrogen to different plots over a 4-year period and found no differences in $\mathrm{NO}_{3}{ }^{-}$ concentrations and field losses in subsurface tile drainage. In the current study and a tile drain study conducted in the Sandy Run and Middle Swamp basins, all sites (including the Lizzie Research Station site) receiving swinelagoon effluent as a fertilizer source had substantially higher $\mathrm{NO}_{3}{ }^{-}$concentrations and yields compared to sites receiving conventional fertilizer, indicating that more total nitrogen probably is applied to the spray sites relative to the conventional sites. Irrigation systems involving applications of

The finding that nitrate concentrations are higher in ground water sprayed with swine wastes in ground water beneath crops fertilized with commercial fertilizer is consistent with recent findings from other studies being conducted in North Carolina and indicates that this site is representative of other hog-producing farms in the Coastal Plain (Spruill and others, 2002). Examination of nitratenitrogen concentrations in ground water beneath cultivated fields in the North Carolina Coastal Plain having different sources of nitrogen applied as fertilizer (Spruill and others, 2002) reveals that highest concentrations occur in ground water beneath fields sprayed with swine wastes and fertilized with poultry litter (fig. 21). Statistically, using a Kruskal Wallis test (Conover, 1980), concentrations of nitrate in ground water beneath fields sprayed with swine wastes were significantly $(\mathrm{p}<0.01)$ higher $($ median $=$ $26 \mathrm{mg} / \mathrm{L}$ ) than in ground water beneath fields fertilized with inorganic commercial fertilizer (median $=14.5 \mathrm{mg} / \mathrm{L})$. Results of another cooperative study in the Contentnea Creek drainage basin (Ragland and others, 2003; Harden and

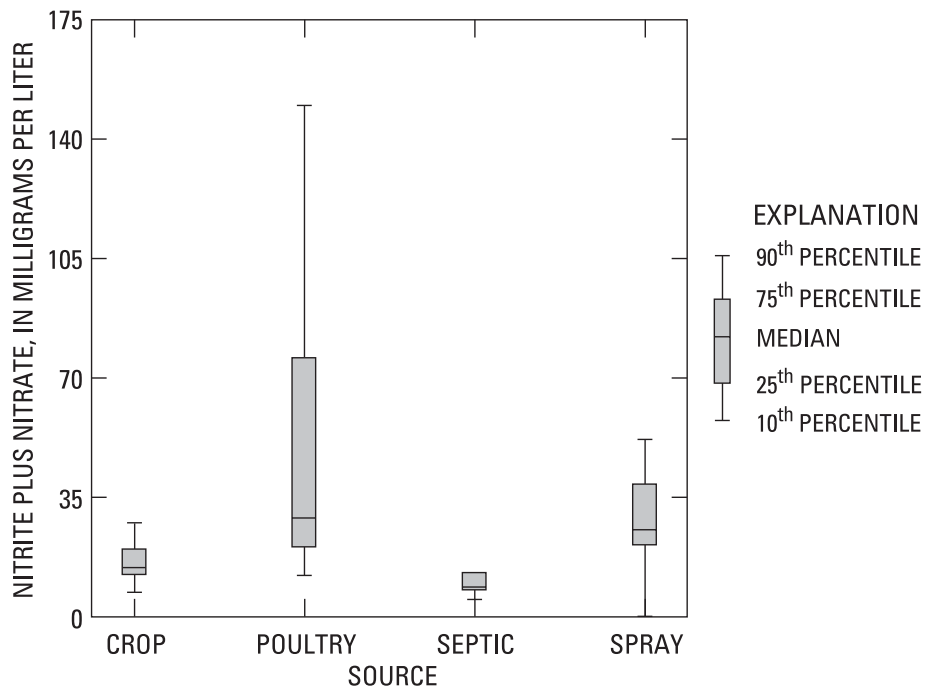

Figure 21. Concentrations of nitrite plus nitrate in ground water from shallow aquifers beneath four areas with selected land uses in the Coastal Plain of North Carolina (modified from Spruill and others, 2002). 


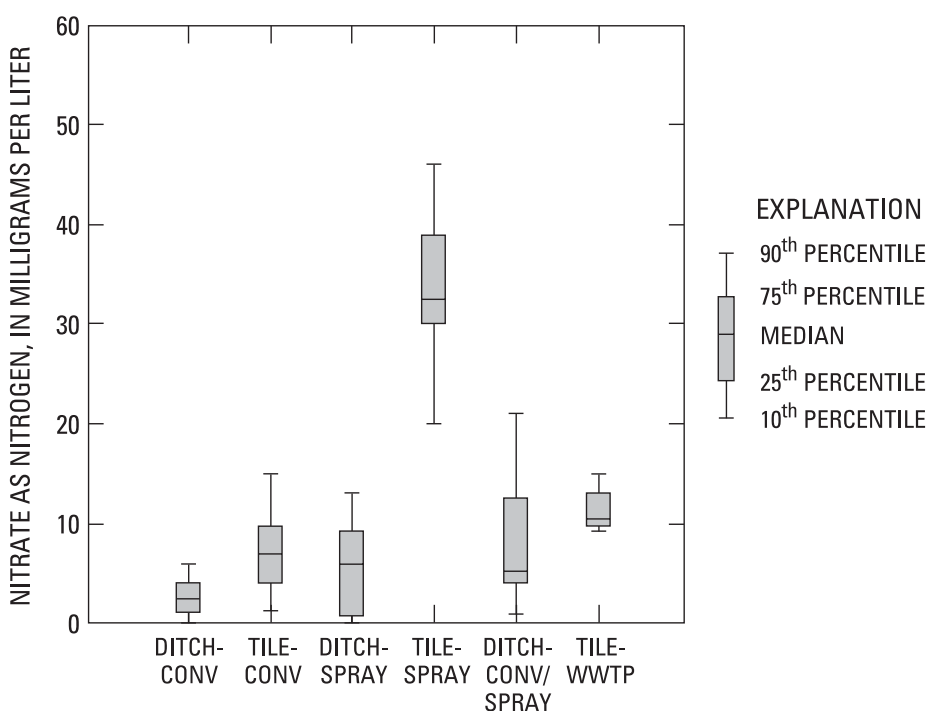

Figure 22. Concentrations of nitrate in fields fertilized with conventional inorganic fertilizer (Conv), sprayed swine waste (Spray), and wastewatertreatment plant sludge (WWTP) in the Little Contentnea Creek subbasin, North Carolina (Harden and Spruill, 2004).

swine-lagoon effluent are designed such that the total nitrogen applied can be utilized by the growing crop to avoid runoff or excessive leaching; however, problems may result from adverse weather conditions or application rates that exceed crop utilization (Evans and others, 1984; Smith and Evans, 1998). Thus, the higher nitrogen loadings for the Lizzie site, as well as other spray sites in the Sandy Run and Middle Swamp watersheds, indicate over-application or applications at times when crops are not growing.

\section{Nutrient Loading in the Neuse River Drainage Basin During Calendar Years 2000 and 2001 in Relation to Background Loads, and Implications of Findings from the Lizzie Research Station Study}

Chemicals and sediment are naturally removed from watersheds by moving water derived from recharge (precipitation) in both surface and ground water through processes of corrasion (physical erosion) or corrosion (dissolution). Although sediment is transported primarily by water through the physical movement of solid or colloidal particles from the land surface, soluble chemicals typically are dissolved in rainwater as it falls onto the land surface and moves either through soils to the water table (percolation) or in runoff to streams.
Chemical loads in rivers are computed according to the following general equation:

$$
\mathrm{L}=\mathrm{C} \times \mathrm{Q},
$$

where $\mathrm{L}=$ mass transport through time; $\mathrm{C}=$ concentration of the chemical constituent (mass/volume); and $\mathrm{Q}=$ discharge, in volume per unit time.

Excess plant nutrients, primarily nitrogen and phosphorus, in aquatic ecosystems are associated with contamination caused by humans and human activities (Schlesinger, 1997). Increased loading of nutrients, primarily nitrogen, through time has been implicated as a reason for environmental problems in the Neuse River basin in North Carolina (North Carolina Department of Environment and Natural Resources, 2001). Spruill and others (1996) noted that Contentnea Creek was responsible for 35 percent of the total nitrogen and 45 percent of the total phosphorus delivered downstream from both the Neuse River at Kinston and Contentnea Creek at Hookerton, indicating that this drainage has a major effect on the Neuse River water quality. Because nitrogen has been implicated by several researchers as the primary nutrient responsible for algal blooms in the Neuse River (Paerl, 1987; Paerl and others, 1995) and because recent research indicates increases in total nitrogen loading, the State of North Carolina in 1997 required a reduction of 30 percent in all sources of nitrogen in the Neuse River basin in order to improve water quality.

Loads of chemical constituents carried by rivers are indicative of the relative abundance of the chemicals in the watershed and may be associated with particular geologic, biologic, and anthropogenic sources. Various nutrient load estimates have been made for the Neuse River since 1992 (Dodd and others, 1992; Harned and others, 1995; McMahon and Woodside, 1997; Stow and Borsuk, 2003). Within the same drainage and same time period, loads can be useful in assessing major sources of particular chemical constituents and in determining likely areas where mass and water are gained or lost in the reach.

While comparisons of stream loads of chemical constituents are particularly useful for identifying possible constituent sources in a basin, it is more difficult to use stream loads to determine temporal trends or to relate to anthropogenic factors. This is largely because flow, which typically is highly variable, has such a large influence on load relative to concentration. For example, flow in the Neuse River at Kinston for the period April 1999 to September 2002 ranged from $260 \mathrm{ft}^{3} / \mathrm{s}$ to more than $35,000 \mathrm{ft}^{3} / \mathrm{s}$ (a ratio of 136 to 1 ) compared to the range in nitrate concentration for the same period of $0.05 \mathrm{mg} / \mathrm{L}$ to about $1 \mathrm{mg} / \mathrm{L}$ (ratio of 20 to 1 ). The calculated load for such a river is influenced more strongly by the relatively large variability in discharge and factors that affect discharge, such as climate and precipitation, relative to concentration. Large apparent changes in load occur in response 
to hydrologic changes during dry or wet years, months, or days; therefore, the effects of change on constituent loads as a result of factors other than climatic factors are difficult to detect. The importance of climatic change on load and the resulting problems associated with causal analysis was noted by Burkholder and others (2004), who found that a series of drought years lowered loads (associated with reduced flow only) and complicated assessment of the effectiveness of bestmanagement practices and other nutrient load-reduction strategies.

A potentially useful technique for evaluating anthropogenic effects on constituent loads was used by Simmons and Heath (1982) to estimate predevelopment or background concentrations for rivers in different geochemical zones in North Carolina. By using a background concentration to calculate a load using current flow data, the effect on loads from anthropogenic activities can be assessed without considering effects due to flow. Possible shortcomings of this technique include (1) incorrect estimated background concentrations and (2) the possibly incorrect assumption that background concentrations estimated for small streams are the same as for large rivers. However, Simmons and Heath (1982) estimated background concentrations with the best information possible for the area and selected a small number of streams from about 200 stream sites that appeared to be as minimally affected by human activities as possible. Caldwell (1992) later updated estimates of background nutrient concentrations for these selected streams.

Assumptions about whether background concentrations for small rivers are the same as for large rivers appear to be reasonable for nitrogen and phosphorus, which are the only constituents considered herein. The issue of stream nutrientprocessing efficiency, particularly with respect to nitrogen, in small as opposed to large streams (Alexander and others, 2000) and its effect on total nitrogen concentrations is assumed to be of minimal importance under presettlement conditions. The primary assumption is that the entire Neuse River basin was forested before European settlement, thus implying a low-level, relatively homogeneous source of nutrients to streams in the area. If it is assumed that during predevelopment times, erosion was minimal (meaning no or low transport of sorbed phosphorus on soil particles from uplands) and that nitrogen sources were limited to only fixed nitrogen from vegetation, then the presence or ability of microflora to process compounds with nitrogen and phosphorus would be of low significance, since concentrations in sediment and water would be low because there were no major sources (relative to current sources of nutrients) of either element for dissolution.

Estimates of background loads using total nitrogen and phosphorus concentration data from Simmons and Heath (1982) were applied to the Neuse River basin (Harned, 1982) and to the Cape Fear River basin (Crawford, 1985) to evaluate anthropogenic effects on stream loads for several chemical constituents. Background nutrient concentrations for streams in the Neuse River basin were selected for the current study by using the middle value between the highest value $(0.69 \mathrm{mg} / \mathrm{L})$ and lowest value $(0.37 \mathrm{mg} / \mathrm{L})$, or about $0.52 \mathrm{mg} / \mathrm{L}$ for total nitrogen and $0.02 \mathrm{mg} / \mathrm{L}$ for total phosphorus (highest value is $0.03 \mathrm{mg} / \mathrm{L}$ and lowest value is $0.01 \mathrm{mg} / \mathrm{L}$ ) in geochemical zones II, IV, and V (Simmons and Heath, 1982). More recently, Smith and others (2003) presented nutrient yield information based on data collected between 1976 and 1997 from streams located in 14 ecoregions of the United States. Median background concentrations for rivers in the eastern Coastal Plain were about $0.55 \mathrm{mg} / \mathrm{L}$ for total nitrogen and $0.015 \mathrm{mg} / \mathrm{L}$ for total phosphorus, which appear to be very comparable to background concentrations used in this study.

Although large main-stem drainages were investigated in previous studies (McMahon and Woodside, 1997; North Carolina Department of Environment and Natural Resources, 2001), no studies have been conducted to evaluate smaller $\left(<500 \mathrm{mi}^{2}\right)$ subdrainages that could contribute significant nitrogen and phosphorus loads to the middle and lower Neuse River basin. In order to evaluate load contributions by small to large streams, annual and seasonal loads were calculated for 14 stations in the Neuse and Contentnea Creek drainage basins for calendar years 2000 and 2001 (table 5; fig. 23) using techniques already described. In this report, loads are shown for 20002001 for all stations for which complete data were collected. Flow data were incomplete for sites S2 (Plum Tree Branch) and N4 (Swift Creek near Streets Ferry) for 2001; therefore, only data for these sites for 2000 are given in table 5. Because flow so greatly affects load calculations, loads are shown for both years where data are available; although as previously indicated, the average daily flow for $2000\left(3,679 \mathrm{ft}^{3} / \mathrm{s}\right.$ for the Neuse River near Fort Barnwell, Ragland and others, 2003) was closer to the long-term (1997-2001) average daily flow for this station $\left(4,707 \mathrm{ft}^{3} / \mathrm{s}\right.$, Ragland and others, 2003) than in 2001 $\left(2,464 \mathrm{ft}^{3} / \mathrm{s}\right)$. Thus, estimated loads for calendar year 2000 were used in making load comparisons with other work conducted in the Neuse River basin and other locations.

Abnormally high primary productivity of streams, lakes, and estuaries - or eutrophication - is often the result of elevated nutrient inflows from human activities and has resulted in a variety of undesirable effects in streams draining the Albemarle-Pamlico drainage basin, such as algal blooms and fish kills (Spruill and others, 1998). Large nutrient additions to the environment, including nitrogen and phosphorus concentrations from such human activities as agriculture and urban waste disposal, have been referred to by several authors as "cultural eutrophication" (Schlesinger, 1997). The relative effects of human activities on water-quality impairment with respect to nutrients, or cultural eutrophication effects, may be evaluated by comparing post-European settlement nutrient concentrations or loads (current conditions in rivers and streams) with pre-European settlement concentrations or loads (background conditions). This comparison for yields (load per unit area) was made in this report by computing the ratio of 
A. TOTAL NITROGEN

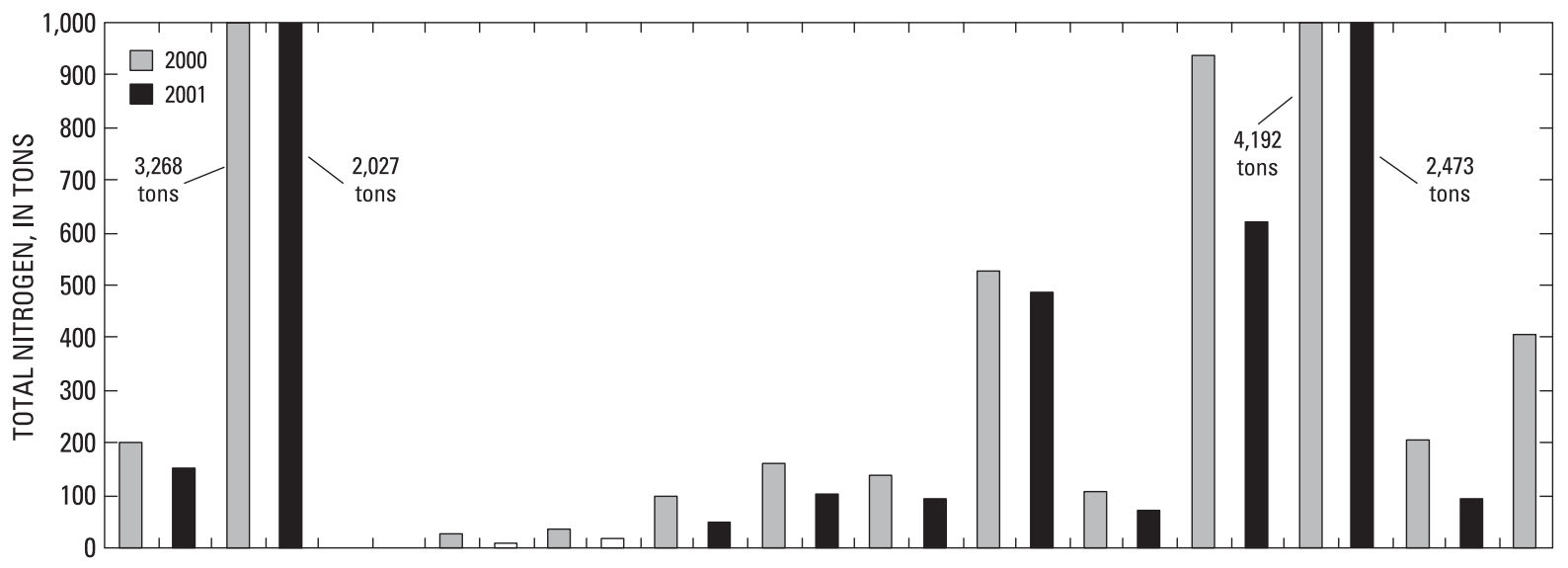

B.

TOTAL PHOSPHORUS

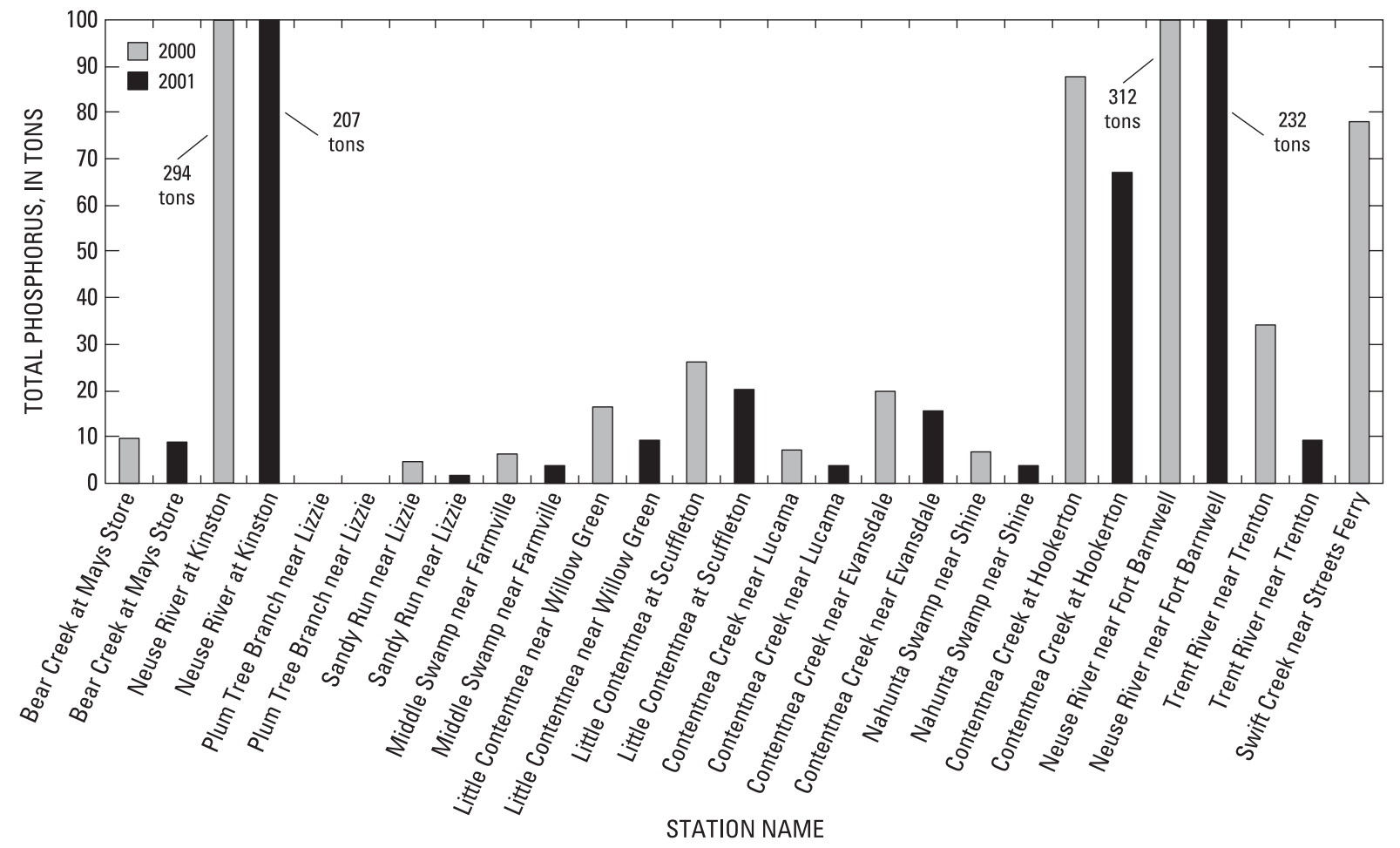

Figure 23. Loads of (A) total nitrogen and (B) total phosphorus transported at 15 stations in calendar years 2000 and 2001 in relation to results from the Lizzie Research Station study, North Carolina.

current annual yield to background annual yield and is referred to as the eutrophication loading index (ELI).

Background loads for calendar years 2000 and 2001 were computed by summing the mean daily flows for each year times the mean daily background concentration for either nitrogen $(0.52 \mathrm{mg} / \mathrm{L})$ or phosphorus $(0.02 \mathrm{mg} / \mathrm{L})$. Background loads for 14 stations for calendar years 2000 and 2001 are presented in table 6. Yields shown in table 6 for both total nitrogen and phosphorus are comparable to the estimated background yields presented in Smith and others (2003). The median total nitrogen yield in the Neuse River was 0.49 ton per square mile per year (ton $/ \mathrm{mi}^{2} / \mathrm{yr}$ ) for the 14 stations, slightly lower than the overall background estimated yield of $0.56 \mathrm{ton} / \mathrm{mi}^{2} / \mathrm{yr}$ for the Coastal Plain of the eastern United States as estimated by Smith and others (2003). The median total phosphorus yield for the 14 stations in the Neuse River was $0.019 \mathrm{ton} / \mathrm{mi}^{2} / \mathrm{yr}$, nearly identical to the $0.018 \mathrm{ton} / \mathrm{mi}^{2} / \mathrm{yr}$ estimated by Smith and others (2003) for the Coastal Plain of the eastern United States. The ELI for both nitrogen and phosphorus is presented in table 6 . 
Table 6. Annual estimated background loads and yields for total nitrogen and total phosphorus for 14 stations in the Neuse River basin, North Carolina.

[USGS, U.S. Geological Survey; tons $/ \mathrm{mi}^{2}$, tons per square mile]

\begin{tabular}{|c|c|c|c|c|c|c|c|}
\hline \multirow[b]{2}{*}{ Station name } & \multirow{2}{*}{$\begin{array}{c}\text { USGS station } \\
\text { number }\end{array}$} & \multirow{2}{*}{$\begin{array}{c}\text { Background } \\
\text { total nitrogen } \\
\text { load } \\
\text { (tons) }\end{array}$} & \multirow{2}{*}{$\begin{array}{c}\text { Background } \\
\text { total nitrogen } \\
\text { yield } \\
\text { (tons } / \mathrm{mi}^{2} \text { ) }\end{array}$} & \multirow{2}{*}{$\begin{array}{c}\text { Background total } \\
\text { phosphorus } \\
\text { load } \\
\text { (tons) }\end{array}$} & \multirow{2}{*}{$\begin{array}{c}\text { Background total } \\
\text { phosphorus } \\
\text { yield } \\
\text { (tons } / \mathrm{mi}^{2} \text { ) }\end{array}$} & \multicolumn{2}{|c|}{ Eutrophication loading index ${ }^{a}$} \\
\hline & & & & & & $\begin{array}{c}\text { Total } \\
\text { nitrogen }\end{array}$ & $\begin{array}{c}\text { Total } \\
\text { phosphorus }\end{array}$ \\
\hline Bear Creek at Mays Store & 208925200 & 30 & 0.5 & 1.2 & 0.02 & 6.7 & 8.3 \\
\hline Neuse River at Kinston & 2089500 & 1,348 & .5 & 54 & .02 & 2.4 & 5.4 \\
\hline Plum Tree Branch & 209173190 & .0001 & .002 & .0001 & .0001 & 1,048 & 352 \\
\hline Sandy Run near Lizzie & 209173200 & 9.2 & .3 & .4 & .01 & 2.9 & 12 \\
\hline Middle Swamp near Farmville & 2091736 & 16 & .3 & 6 & .01 & 2.4 & 10 \\
\hline Little Contentnea near Willow Green & 2091737 & 47 & .3 & 1.9 & .01 & 2.1 & 8.9 \\
\hline Little Contentnea at Scuffleton & 2091740 & 83 & .5 & 3.3 & .02 & 1.9 & 7.9 \\
\hline Contentenea Creek near Lucama & 2090380 & 86 & .5 & 3.5 & .02 & 1.6 & 2.1 \\
\hline Contentnea Ceek near Evansdale & 2090519 & 136 & .5 & 5.4 & .02 & 3.9 & 3.6 \\
\hline Nahunta Swamp near Shine & 2091000 & 32 & .4 & 1.3 & .03 & 3.4 & 5.2 \\
\hline Contentnea Ceek at Hookerton & 2091500 & 378 & .5 & 15 & .02 & 2.5 & 5.8 \\
\hline Neuse River near Fort Barnwell & 2091814 & 1,867 & .5 & 75 & .03 & 2.2 & 4.2 \\
\hline Trent River near Trenton & 2092500 & 96 & 6 & 3.9 & .02 & 2.2 & 8.8 \\
\hline Swift Creek near Streets Ferry & 209205053 & 158 & 6 & 6.3 & .02 & 2.6 & 12 \\
\hline \multicolumn{8}{|c|}{ Calendar year 2001} \\
\hline Bear Creek at Mays Store & 208925200 & 22 & 0.4 & 0.9 & 0.01 & 7 & 10 \\
\hline Neuse River at Kinston & 2089500 & 930 & .3 & 37 & .01 & 2.2 & 5.5 \\
\hline Sandy Run near Lizzie & 209173200 & 3.9 & .1 & .2 & .01 & 2.7 & 12 \\
\hline Middle Swamp near Farmville & 2091736 & 7.4 & .1 & .3 & .01 & 2.4 & 12 \\
\hline Little Contentnea near Willow Green & 2091737 & 26 & .2 & 1.0 & .01 & 2 & 8.9 \\
\hline Little Contentnea at Scuffleton & 2091740 & 50 & .3 & 2 & .01 & 2.1 & 10 \\
\hline Contentenea Ceek near Lucama & 2090380 & 58 & .4 & 2.3 & .01 & 1.6 & 1.6 \\
\hline Contentnea Ceek near Evansdale & 2090519 & 93 & .4 & 3.7 & .01 & 5.2 & 4.2 \\
\hline Nahunta Swamp near Shine & 2091000 & 22 & .5 & .9 & .01 & 3.3 & 4.4 \\
\hline Contentnea Ceek at Hookerton & 2091500 & 260 & .4 & 10 & .01 & 2.4 & 6.5 \\
\hline Neuse River near Fort Barnwell & 2091814 & 1,184 & .3 & 47 & .01 & 2.1 & 4.9 \\
\hline Trent River near Trenton & 2092500 & 41 & .2 & 1.6 & .01 & 2.3 & 5.6 \\
\hline
\end{tabular}

${ }^{a}$ Actual yield divided by estimated background yield. 


\section{Atmospheric Nutrient Loads in the Plum Tree Branch and Sandy Run Subbasins}

Monthly precipitation totals measured at a weather station near Lizzie, N.C. (stations 0209173196, S1-A, fig. 2, and 353137077332801, S1-B, fig. 2), were summed to produce annual precipitation totals for 2000 and 2001. The drainage areas of Plum Tree Branch and Sandy Run were then multiplied by these totals, and the results were converted to liters and multiplied by the median measured concentration of nitrogen from precipitation samples. Based on this method, atmospheric deposition at Plum Tree Branch (S2, fig. 2) was estimated to be 1.14 tons of nitrogen in 2000 (about 2 tons $/ \mathrm{mi}^{2}$ ) and 0.51 ton in 2001 (about 1 ton $/ \mathrm{mi}^{2}$ ). In Sandy Run (S4, fig. 2), atmospheric deposition was determined to be 60 tons of nitrogen in 2000 and 26.7 tons in 2001. In 2000, atmospheric phosphorus deposition in the Plum Tree Branch watershed was estimated to be 0.0012 ton, and 0.006 ton in the Sandy Run watershed. Loads for 2001 were not calculated because the detection limit was too high (all values were reported as $<0.007 \mathrm{mg} / \mathrm{L}$ in 2001).

\section{Little Contentnea Creek Subbasin}

Annual nutrient loads in the Little Contentnea Creek drainage subbasin for calendar years 2000 and 2001 for Plum Tree Branch (S2), Sandy Run (S4), Middle Swamp (S5), Little Contentnea Creek near Willow Green (S6), and Little Contentnea Creek at Scuffleton (S16, fig. 2) ranged from about 0.8 ton to about 160 tons for total nitrogen and from 0.02 ton to 26 tons for total phosphorus (fig. 23). Yields for total nitrogen ranged from 0.33 to 2.53 tons $/ \mathrm{mi}^{2}$ (fig. 24) and for total phosphorus from 0.02 to about $0.15 \mathrm{ton} / \mathrm{mi}^{2}$ (fig. 25). Based on nitrogen and phosphorus seasonal load data (table 5), 69 to 87 percent of the total nitrogen and 55 to 81 percent of the total phosphorus load was transported during the winter and spring.

All streams included in this study had lower nitrogen yields (less than 1 ton $/ \mathrm{mi}^{2}$ ) than the first-order Plum Tree Branch $\left(2.53\right.$ tons $\left./ \mathrm{mi}^{2}\right)$. Sandy Run, a second-order stream that drains about $30 \mathrm{mi}^{2}$, transported between 0.3 and 0.8 ton $/ \mathrm{mi}^{2}$ during 2000-2001. The next two downstream sampling points S5 (Middle Swamp near Farmville, drainage area $=51 \mathrm{mi}^{2}$ ) and S6 (Little Contentnea Creek near Willow Green, drainage area $=152 \mathrm{mi}^{2}$ ) transported between 0.3 and $0.74 \mathrm{ton} / \mathrm{mi}^{2}$ (fig. 24; tables 1, 2). Little Contentnea Creek at Scuffleton (S16) transported slightly more nitrogen, $0.9 \mathrm{ton} / \mathrm{mi}^{2}$ in 2000 and $0.6 \mathrm{ton} / \mathrm{mi}^{2}$ in 2001. During 2000 and 2001, the total nitrogen loads were more than 1,000 times the estimated background loads for the first-order stream, Plum Tree Branch, and about two times or less the estimated background loads in the third- and higher-order streams in the Little Contentnea Creek drainage basin. Total nitrogen yields for second- or higher-order streams ranged from 0.35 to about $0.95 \mathrm{ton} / \mathrm{mi}^{2}$, with a median load of about $0.60 \mathrm{ton} / \mathrm{mi}^{2}$. However, nitrogen

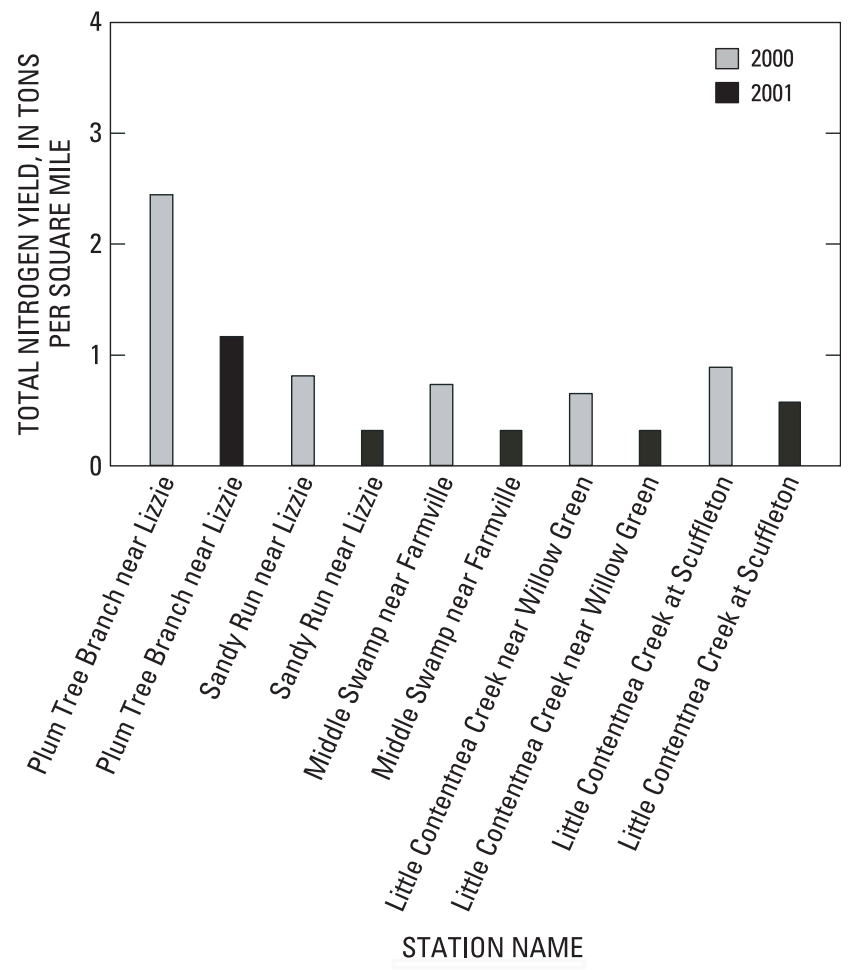

Figure 24. Annual total nitrogen yield at selected stations in the Little Contentnea Creek subbasin, North Carolina.

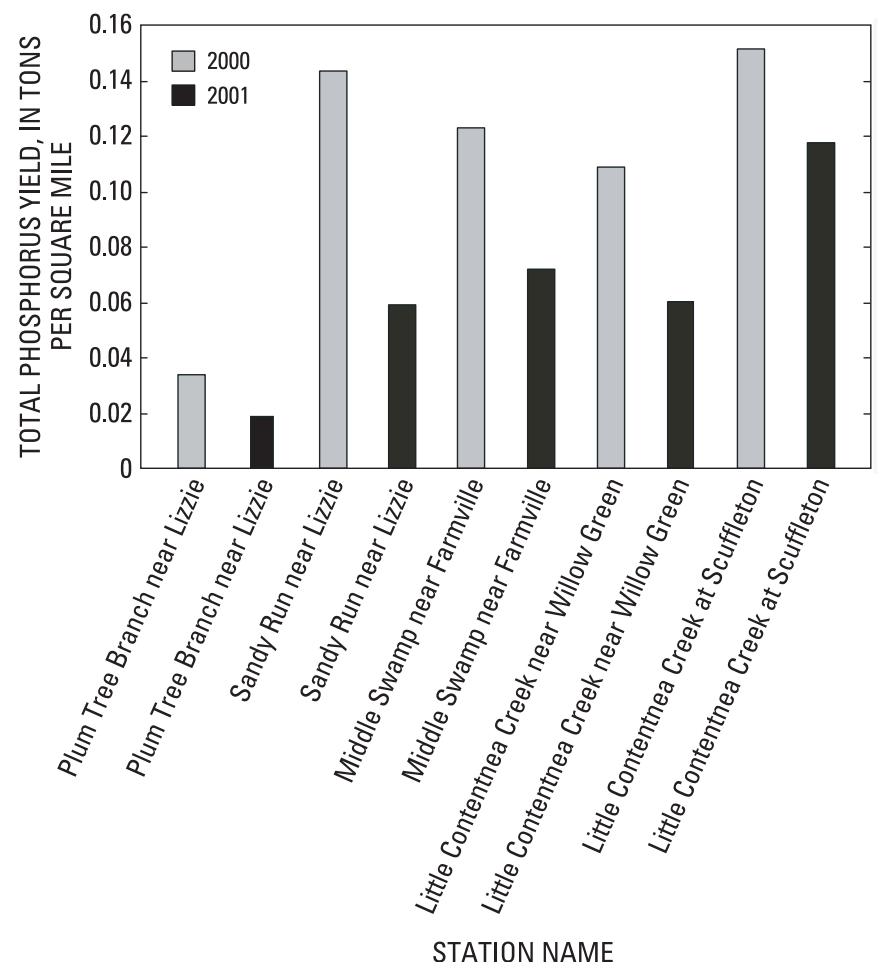

Figure 25. Annual total phosphorus yield at selected stations in the Little Contentnea Creek subbasin, North Carolina. 
transport from the small first-order stream, Plum Tree Branch, was much higher relative to the larger second- and higher-order streams, implying loss of nitrogen as it moved through the drainage basin.

Phosphorus behaves differently, however. Although total phosphorus yields in Plum Tree Branch were more than 300 times the estimated background loads and second- and higherorder streams in the subbasin transported approximately 8-12 times the estimated background phosphorus load in 2000 and 2001, overall phosphorus yields were higher in larger streams than in the first-order Plum Tree Branch (fig. 25) and remained fairly constant at downstream stations. In contrast to total nitrogen yields, larger total phosphorus yields were found in the higher-order streams (about three times greater), indicating either that a major source of phosphorus in the Little Contentnea Creek subbasin originates in the larger streams, such as detritus from vegetation deposited in sediments, or that phosphorus load estimates for Plum Tree Branch are too low, perhaps because of inadequate sampling of high-flow events. The low phosphorus loads measured in Plum Tree Branch may be because extreme high flows that could mobilize sediment movement were not represented by the monthly water samples.

Anthropogenic activities in the basin have caused much greater increases in phosphorus loads than nitrogen loads relative to expected background loads, with greatest effect of phosphorus enrichment occurring in the higher-order streams. Geochemical processes that occur in this basin, as demonstrated at the Lizzie Research Station site, suggest that coincident processes and mobilization and release of phosphorus under reducing conditions in aquifers and streams in this region may account for the relatively greater observed anthropogenic enrichment of phosphorus relative to nitrogen.

\section{Contentnea Creek Subbasin}

Contentnea Creek is considered a major contributor of nitrogen and phosphorus to the Neuse River (Spruill and others, 1996). Nutrient loads transported at four stations in the Contentnea Creek basin are shown in figures 26 and 27. The most upstream station sampled for this study, Contentnea Creek near Lucama (S11, fig. 1), which drains about $159 \mathrm{mi}^{2}$ and is located just downstream from Buckhorn Reservoir, transported 0.87 and 0.6 ton $/ \mathrm{mi}^{2}$ of total nitrogen in 2000 and 2001 , respectively, which is about 1.6 times more than the estimated background load for total nitrogen (fig. 26). This station transported about 0.05 and $0.02 \mathrm{ton} / \mathrm{mi}^{2}$ of total phosphorus in 2000 and 2001, respectively, which is about 2 and 1.5 times the expected background load (fig. 27). Contentnea Creek near Lucama had the lowest ELI (1.6 for nitrogen and 2.1 for total phosphorus, table 6) of all streams included in this investigation. This may be in part because the station is located downstream from a reservoir, which may remove much of the nitrogen and phosphorus load. Seasonally, between 55 and 92 percent of the total nitrogen and 56 and 81 percent of the total phosphorus were transported during the winter and spring (table 5).

The next site downstream, Contentnea Creek near Evansdale (S14, fig. 1), transported 2.0 and 1.84 tons $/ \mathrm{mi}^{2}$ of total nitrogen in 2000 and 2001 (fig. 26), which were about 5.2 and 3.8 times, respectively, the expected background total nitrogen load for these years. This site apparently receives substantial quantities of nitrogen and has the highest yields in the basin, which decrease downstream to Hookerton (fig. 26). Contentnea Creek near Evansdale (S14) transported about 0.07 and $0.06 \mathrm{ton} / \mathrm{mi}^{2}$ of total phosphorus in 2000 and 2001 (fig. 27), which were about 3.6 and 4 times the estimated background loads (table 6).

Nahunta Swamp, the next major tributary inflow to Contentnea Creek, also transported more than three times the estimated background load for total nitrogen. Phosphorus yields increased at the next downstream station, Contentnea Creek at Hookerton (S18, fig. 1), indicating new sources of phosphorus. This site, which is the most downstream station in the Contentnea Creek drainage basin before receiving inflow from Little Contentnea Creek, transported 1.28 and 0.85 ton $/ \mathrm{mi}^{2}$ of total nitrogen in 2000 and 2001, respectively (fig. 26), about two times the expected total nitrogen background load. This station transported 0.12 and 0.09 ton $/ \mathrm{mi}^{2}$ of total phosphorus, the second highest observed in the subbasin and about five to six times the expected background load. As noted for the Little Contentnea Creek subbasin, the generally greater ELI of phosphorus relative to nitrogen may be because of reducing

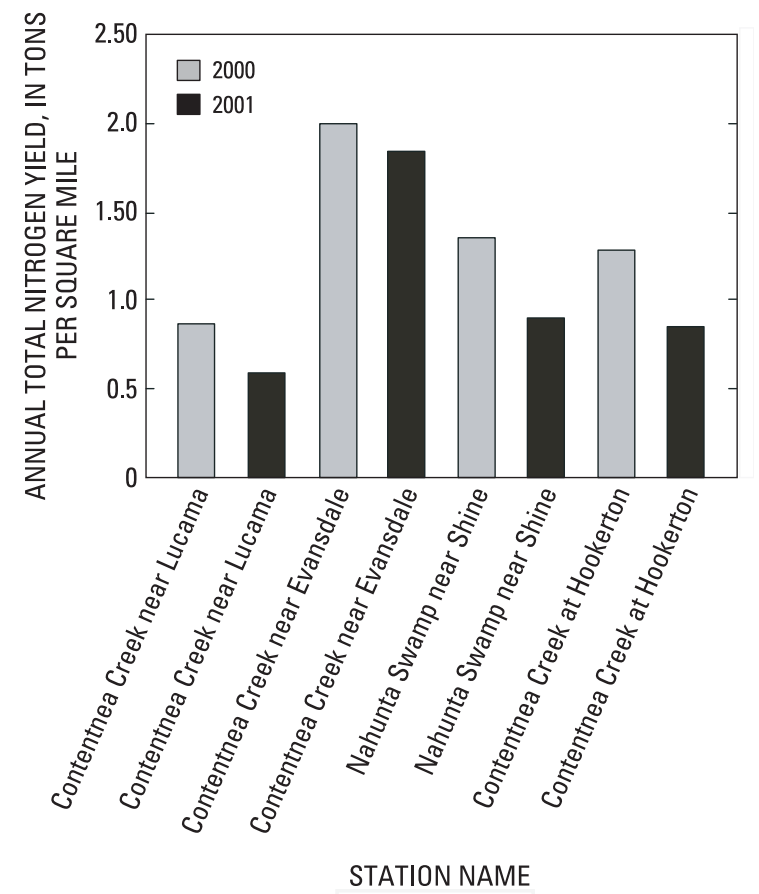

Figure 26. Annual total nitrogen yield at selected stations in the Contentnea Creek subbasin, North Carolina. 


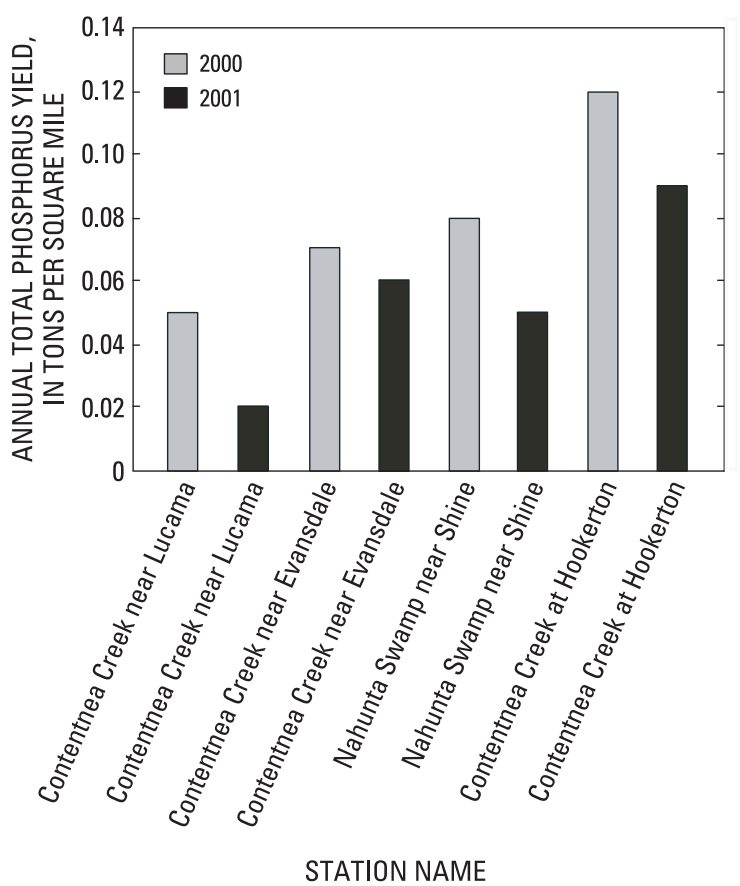

Figure 27. Annual total phosphorus yield at selected stations in the Contentnea Creek subbasin, North Carolina.
(McMahon and Lloyd, 1995) to 42 percent in 1999 (Harned, 2003).

\section{Neuse River Basin}

Total nitrogen yields for five stations in the Neuse River drainage basin are shown in figure 28. Bear Creek (N1, fig. 1), which drains into the Neuse River just west of Kinston, N.C., transported 3.4 and 2.6 tons $/ \mathrm{mi}^{2}$ of total nitrogen in 2000 and 2001, respectively, about seven times the expected background load. The ELI for this site is one of the highest observed for all sites included in this study (table 6). Total phosphorus yields at this site were 0.17 and $0.15 \mathrm{ton} / \mathrm{mi}^{2}$, or about $8-10$ times the background yield (fig. 29; table 6). Because no National Pollutant Discharge Elimination System (NPDES)-permitted dischargers are reported to be in the Bear Creek watershed, it is assumed that the entire nutrient load is derived from nonpoint sources. Because Bear Creek had some of the highest yields for both nitrogen and phosphorus, further study of this watershed could provide useful information about the fate and transport of nutrients and provide an opportunity to evaluate the effectiveness of land-management practices. The Bear Creek basin has the highest percentage of cropland (59 percent) of all basins included in this study (table 1), and a previous study (Woodside and Simerl, 1995) indicated that this basin had more than 1.5 million poultry in 1994 .

conditions in aquifer sediments and streams in the watershed

that reduce nitrogen and release phosphorus.

The 2000 and 2001 yields for nitrogen and phosphorus reported for Contentnea Creek at Hookerton are considerably lower than those reported by McMahon and Woodside (1997) for 1990 (total nitrogen yield $=1.83$ tons $/ \mathrm{mi}^{2}$; total phosphorus yield $=0.21$ ton $/ \mathrm{mi}^{2}$ ). Average streamflow in 1990, 2000, and 2001 for Contentnea Creek at Hookerton was 677, 767, and $529 \mathrm{ft}^{3} / \mathrm{s}$, respectively (U.S. Geological Survey, 2004); therefore, the change in load was probably not due to a major difference in streamflow. Harned (2003) reported a decrease in both total nitrogen and phosphorus concentrations between 1974 and 2003 and suggested that part of this decrease could be a result of the implementation of the 1997 NCDENR DWQ management rules to reduce nitrogen loading to the Neuse River. Another possibility is that the percentage of agricultural land since the late 1980s in the entire Contentnea Creek watershed has decreased from 50 percent in 1987

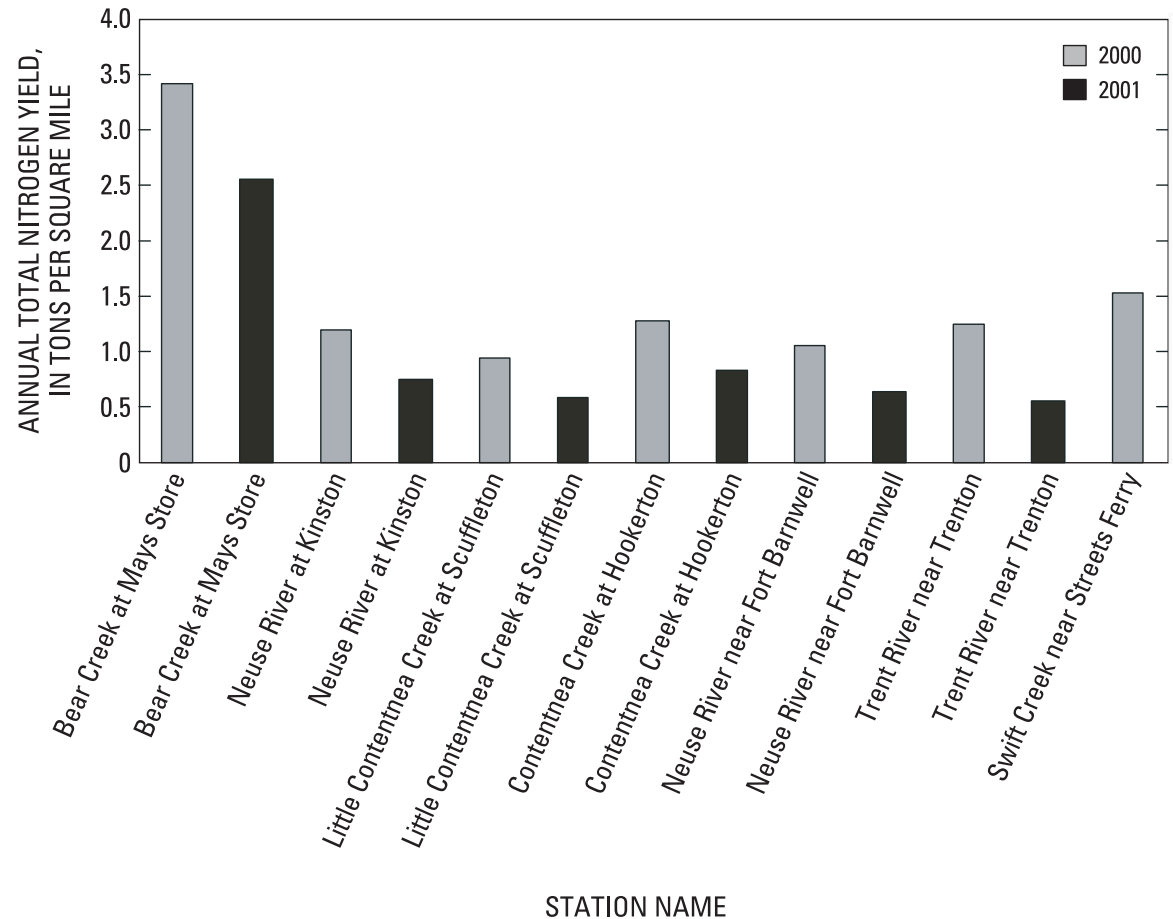

Figure 28. Annual total nitrogen yield at selected stations in the Neuse River basin, North Carolina. 


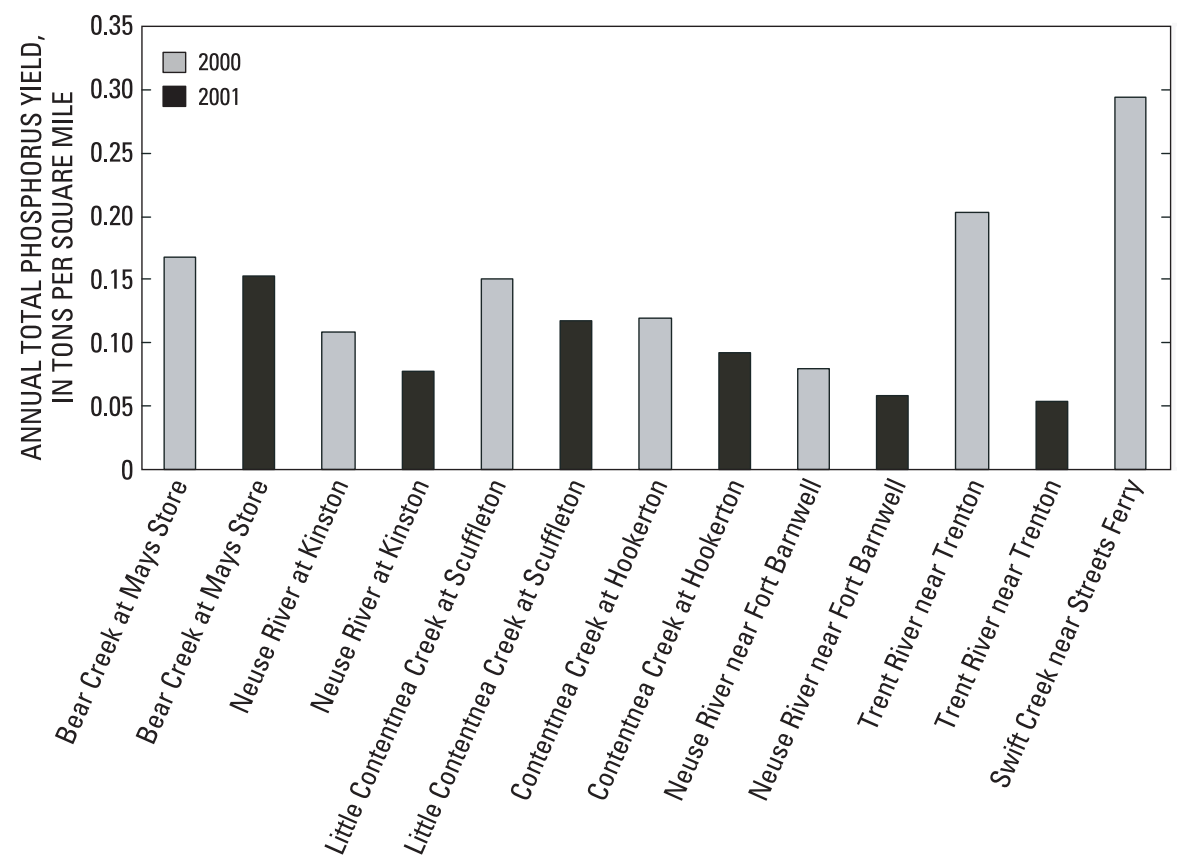

STATION NAME eutrophication effects are an issue, determining the reasons the loads of phosphorus near New Bern are elevated is worthy of further investigation. Possible reasons for elevated phosphorus loads from these streams are geochemically reducing ground water moving from aquifers that may contain high phosphorus concentrations and water moving through phosphorus-laden sediment that could contribute substantial phosphorus loads to the estuary near New Bern.

Because both Swift Creek and the Trent River directly discharge to the Neuse River estuary, the large amount of phosphorus entering from these two streams is likely to cause nitrogen to be the growthlimiting element for phytoplankton in this portion of the estuary, particularly during summer months when 32 percent of the phosphorus load to the estuary is from both Swift Creek and the Trent River (table 5). Because few point-source dischargers are located in Swift Creek and none in the Trent River (sites N4 and N5, table 1), it appears likely that phosphorus from these two North Carolina.

The Neuse River at Kinston (N2, fig. 1) yield was 1.21 and 0.75 tons $/ \mathrm{mi}^{2}$ for 2000 and 2001, respectively, two times higher than the background yield for nitrogen (fig. 28; table 6). The total phosphorus yields were 0.11 and $0.08 \mathrm{ton} / \mathrm{mi}^{2}$ (fig. 29), about five times the expected loading rate for background conditions. These nutrient yields are slightly lower than those reported for 1990 by McMahon and Woodside (1997), when the total nitrogen yield was 1.62 tons $/ \mathrm{mi}^{2}$ and the total phosphorus yield was 0.12 ton $/ \mathrm{mi}^{2}$.

The Neuse River near Fort Barnwell (N3, fig.1) had total nitrogen yields of 1.06 and 0.63 tons $/ \mathrm{mi}^{2}$ in 2000 and 2001 , respectively (fig. 28), about twice the estimated background yield (table 6). Total phosphorus transported at this site, 0.08 and $0.06 \mathrm{ton} / \mathrm{mi}^{2}$ (fig. 29), was four and five times the expected background load.

The Trent River near Trenton (N5, fig. 1) transported 1.24 and 0.55 tons $/ \mathrm{mi}^{2}$ of nitrogen in 2000 and 2001, respectively, and Swift Creek near Streets Ferry (N4, fig. 1) transported 1.54 tons $/ \mathrm{mi}^{2}$ in 2000 (fig. 28). Nitrogen yields were between two and three times the background, similar to other streams in the Neuse River basin. Phosphorus yields in 2000 from the Trent River (0.2 ton $\left./ \mathrm{mi}^{2}\right)$ and Swift Creek (0.29 ton $/ \mathrm{mi}^{2}$; fig. 29) were the highest observed for all of the streams included in this study and 8 and 12 times, respectively, the estimated background yields (table 6). The combined total phosphorus load from Swift Creek and Trent River for 2000 was 114 tons, about 26 percent of the total load entering the Neuse River estuary at New Bern (fig. 1), which represents only about 10 percent of the contributing drainage area. Because these two streams are located so near the upper Neuse estuary where watersheds is derived from nonpoint sources.

\section{Loads and Sources of Nutrients to the Neuse Estuary, Calendar Year 2000}

Water quality of the Neuse River and estuary has been impaired in the past by an overabundance of nutrients (Tedder and others, 1980; Paerl, 1987; Paerl and others, 1995;

Burkholder and Glasgow, 1997; Spruill and others, 1998; Stow and Borsuk, 2003). Section 303D of the Clean Water Act of 1972 requires that States identify impaired water bodies and implement a total maximum daily load (TMDL) for each problem contaminant (McMahon and others, 2003). The NCDENR DWQ (North Carolina Department of Environment and Natural Resources, 2001) determined that excessive chlorophyll $a$ occurs in the estuary between the Streets Ferry Bridge and Cherry Point and, based on research conducted over the last decade, found that "nitrogen has the best potential to limit chlorophyll $a$ in the estuary." According to the NCDENR (1999), phosphorus was eliminated as a nutrient to control chlorophyll $a$ primarily because (1) nitrogen to phosphorus ratios generally indicate nitrogen limitation in the Neuse River estuary, (2) much of the phosphorus loading in the Neuse estuary was naturally occurring and extremely difficult to manage, and (3) phosphorus loads have decreased over much of the basin, so that reducing phosphorus loads will not have as much effect as reducing nitrogen loads. Thus, nitrogen was the primary nutrient targeted to control the occurrence of chlorophyll $a$ in the Neuse estuary (North Carolina Department 
of Environment and Natural Resources, 2001). A 30-percent reduction from 9.65 million pounds baseline load to 5.92 million pounds for New Bern (North Carolina Department of Environment and Natural Resources, 2001) was adopted as the total nitrogen TMDL.

In order to reach the Neuse TMDL goal, an accurate accounting of the amount of nitrogen entering the estuary is necessary before the effectiveness of nitrogen reductions can be measured. In addition to the total quantity of a nutrient delivered, an accurate accounting of the quantity delivered by individual source categories is required in order to determine where and how much each nutrient can be reduced. A major objective of this study is to characterize nitrogen loading in streams draining the Neuse River, not just for simple accounting of loads transported by various streams but also in light of processes that appear to be occurring in the watershed at varied scales. Findings from research activities conducted at the Lizzie Research Station to improve understanding of nutrient transport could assist in management of the Neuse River.

In order to understand nutrient transport in the Neuse River and the Neuse River estuary, several studies have attempted to account for nitrogen loading (Dodd and others, 1992; Harned and others, 1995; North Carolina Department of Environment and Natural Resources, 2001; McMahon and others, 2003) and nitrogen and phosphorus (McMahon and Woodside, 1997). Some of the more recent efforts associated with development of a nitrogen TMDL are described in NCDENR (2001).

The following discussion includes estimates of total nitrogen loads delivered to the Neuse River estuary in 2000 (fig. 30) made in this study and in two other recent studies (North Carolina Department of Environment and Natural Resources, 2001; McMahon and others, 2003) to provide and compare estimation methods to management with respect to the accuracy and practical application of each method, and to provide possible reasons why the estimates differ. Because many of the TMDL discussions in NCDENR (2001) refer to pounds as the unit of mass transported, pounds of nutrients are shown with tons transported for the reader's convenience. Estimates for phosphorus loads also are discussed. Nutrient loads at the Neuse River near Fort Barnwell (N3), Swift Creek near Streets Ferry (N4), and Trent River near Trenton (N5, fig. 1) are presented for calendar year 2000 only because discharge data from Swift Creek near Streets Ferry were incomplete for calendar year 2001 and because, hydrologically, calendar year 2000 was closer to the average flow conditions for the Neuse River, as indicated previously.

Based on results from this study, the total nitrogen load delivered to the Neuse River estuary near New Bern, N.C. (fig. 1), in 2000 was 4,807 tons (table 5), or 9.61 million pounds, and 425 tons for total phosphorus (table 5), or 850,000 pounds. It is estimated that about 17 percent (1,630,000 pounds) of the delivered total nitrogen load is due to background sources based on the background total nitrogen concentration of $0.50 \mathrm{mg} / \mathrm{L}$ used in this analysis. This background estimate is larger than the 8.6-percent ( 830,000 pounds) background total nitrogen load reported by
NCDENR (2001) for 1995, but less than the 30 percent estimated by the USGS spatially referenced regression on watershed (SPARROW) attributes study (McMahon and others, 2003) for 1992. The average total nitrogen load, based on data from Fort Barnwell, Trent River, and wastewater-treatment plants (WWTP) below Fort Barnwell and delivered to the Neuse estuary, was 9.65 million pounds for the base period (1991-95; North Carolina Department of Environment and Natural Resources, 2001). The load reported herein for calendar year 2000 (9.61 million pounds) is comparable to the load for the base period.

The background load estimate from this report (1.63 million pounds), based on the percentage of forested land in each basin in 2000 multiplied by the sum of background loads for 2000 from Fort Barnwell, Swift Creek near Streets Ferry, and Trent River near Trenton, assuming 100-percent forested land cover for all three basins (4.24 million pounds), was used as a basis for estimating anthropogenic contributions of nitrogen. The total 9.61 million pounds of total nitrogen delivered during 2000 minus the estimated background load of 1.63 million pounds (which consists primarily of loads from forested land), yielded an anthropogenic load, by difference, of approximately 7.98 million pounds. Using the 1995 pointsource contribution of 3.32 million pounds as an estimate of point-source load (North Carolina Department of Environment and Natural Resources, 2001), the anthropogenic nonpointsource load in the Neuse basin would be 4.66 million pounds, somewhat less than the 5.5 million pounds estimated to be from nonpoint sources reported by NCDENR (2001) and 8.12 million pounds estimated from 1992 data using SPARROW (McMahon and others, 2003, and Gerard McMahon, U.S. Geological Survey, written commun., 2004).

The variation of load estimates by three different approaches raises questions about accuracy and comparability of different methods used to estimate loads from different sources. Primary reasons for the observed variability in methods relate to flow conditions used in computations and methods used to compute individual source loads. The percentages of total nitrogen in water transported from the Neuse River basin into the Neuse estuary from background and anthropogenic point and nonpoint sources from this study, the NCDENR TMDL study (North Carolina Department of Environment and Natural Resources, 2001), and from the SPARROW model (McMahon and others, 2003, and Gerard McMahon, U.S. Geological Survey, written commun., 2003) are shown in figure 30 . These graphs show relatively wide variations in loads transported to the Neuse estuary, from 14 million pounds in 1992 (SPARROW model, McMahon and others, 2003), 9.65 million pounds for the period 1991-95 (North Carolina Department of Environment and Natural Resources, 2001), and 9.61 million pounds in 2000, as reported in this study. Individual source category load estimates also varied widely. Background loads ranged from 9 percent (North Carolina Department of Environment and Natural Resources, 2001) to more than 30 percent of the total nitrogen load determined by the SPARROW model (McMahon and others, 
STATE TMDL (North Carolina Department of Environment and Natural Resources, 2001)

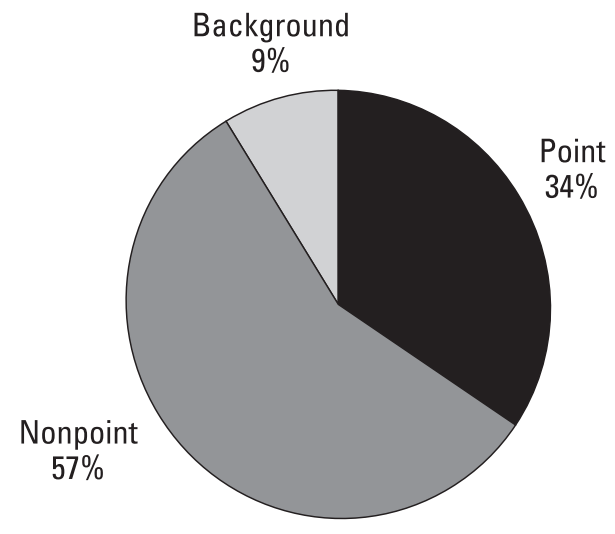

THIS REPORT (Data from 2000)

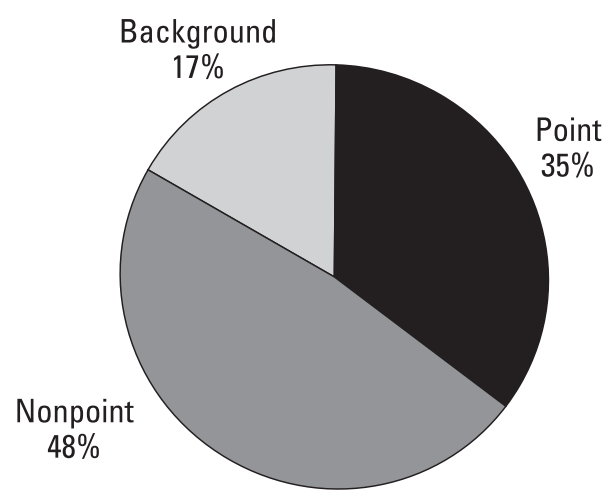

Total nitrogen, in millions of pounds

Total load $\quad 9.65$

Background $\quad 0.83$

Point $\quad 3.32$

Nonpoint $\quad 5.50$

Total nitrogen, in millions of pounds

Total load $\quad 9.61$

Background $\quad 1.63$

Point $\quad 3.32$

Nonpoint $\quad 4.66$

SPARROW (McMahon and others, 2003; and Gerard McMahon,

U.S. Geological Survey, written commun., June 2004, 1992 data)

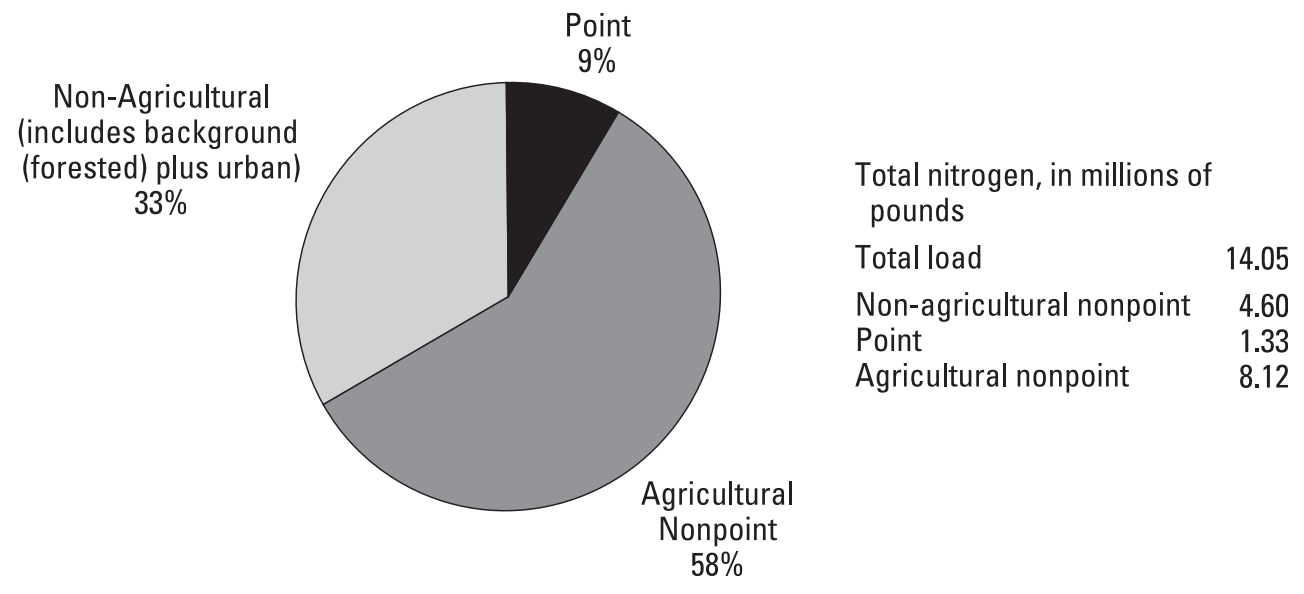

Figure 30. Sources of total nitrogen, estimated by three different methods, delivered to the Neuse River estuary at New Bern, North Carolina. 
2003, and Gerard McMahon, U.S. Geological Survey, written commun., 2004). The point-source load varied from 9 percent in 1992 to more than 30 percent in both 1995 and 2000 (fig. 30).

Because data from NCDENR were used in two of the three methods-North Carolina Department of Environment and Natural Resources (2001) and this study - based on information filed by individual dischargers to the North Carolina DWQ for 1995, the resulting large difference in point-source load contribution between the SPARROW model and this study and the NCDENR (2001) report underscores the need for a standard reproducible method to compute point-source loads to streams. Although possible, it appears unlikely that the point-source load was lower (1.33 million pounds from the SPARROW model) in 1992 than in 1995, particularly assuming improved treatment technology through time. One likely reason for the observed difference is the method used for point-source load determination. Because point-source loads are the most regulated and controllable source information for nutrients, improved data (minimum of daily discharge with daily concentration data), improved data storage and retrieval capability, and standard methods of reporting and computing point-source discharge data could greatly increase the accuracy and reduce the variability of this very important, if not the most important, source of nutrient load information.

Background nitrogen estimates used for the three different methods also account for much of the variability observed. McMahon and others (2003) used a SPARROW model coefficient of $0.51 \mathrm{ton} / \mathrm{mi}^{2}$. This method resulted in a background load of about 4.6 million pounds delivered to the Neuse estuary, or 30 percent of the total load, under the average flow conditions used for developing the SPARROW model. The background load for the Neuse used by NCDENR (2001) also was determined by using land delivery coefficients $\left(0.53 \mathrm{ton} / \mathrm{mi}^{2}\right)$ from Dodd and others (1992), which resulted in 86,000 pounds, the lowest background load of the three methods considered. According to methods used for development of the TMDL reported by NCDENR (2001), expected yields in tons per acre from each source were computed for each land-use category and then proportionally allocated to the annual load that remained after subtracting the estimated point-source load from the total delivered nitrogen load. For this report, as described previously, the background concentration of $0.50 \mathrm{mg} / \mathrm{L}$ was used for forested land, the expected load was computed from the actual amount of forested land in each basin, and then this amount was subtracted from the total load at New Bern, N.C.

The advantage of the method used for calculating background loads for this report, compared to the other two methods described, is that the background load (1) is calculated independently of the other loads used in the total load calculations and (2) is based on measured concentrations from streams that are thought to best represent background conditions. As shown earlier, these concentrations compare favorably with concentrations derived independently by Smith and others (2003). In addition, because the background quantity used for this report is a concentration, monthly, seasonal, or annual loads also can be calculated easily using available flow information. Both the SPARROW and NCDENR (2001) methods are dependent on the point loads used in the computation-loads are allocated across the remaining source categories after the point-source load has been subtracted. Therefore, the difference in point-source load magnitude used in McMahon and others (2003) and by NCDENR (2001) could largely account for the widely different background loads reported.

The total phosphorus load transported to the Neuse estuary in 2000 was 425 tons. As for nitrogen, accurate and easily available point-source information is necessary for computing meaningful phosphorus loads. Because of the focus on nitrogen over the last decade, however, no recent published information was found on total point-source contributions of phosphorus to the Neuse River near Fort Barnwell; therefore, general estimates from past studies were used. Based on previous estimates of total phosphorus load of $0.04 \mathrm{ton} / \mathrm{mi}^{2}$ from point sources in the Albemarle-Pamlico drainage basin (Stanley, 1989), which also was used by McMahon and Woodside (1997), about 175 tons of phosphorus were estimated delivered to the estuary by point sources in 2000 . Also, as was done for nitrogen, background phosphorus was calculated by multiplying the actual percentage of forested area in each of the three basins by the total background loads computed assuming 100 percent forested land cover for each basin. By adding the estimated background load of 31 tons obtained using the background phosphorus concentration of $0.02 \mathrm{mg} / \mathrm{L}$ (Simmons and Heath, 1982; Smith and others, 2003) to the point-source load of 175 tons and subtracting this sum from the total load to the Neuse estuary, the resulting nonpoint total phosphorus load was 219 tons in 2000. Based on this analysis, about 7 percent was from background sources with about 93 percent of the total phosphorus load in 2000 derived from anthropogenic point (41 percent) and nonpoint (52 percent) sources (fig. 31).

The analysis of phosphorus loads from this study raises questions regarding background sources of phosphorus because previous researchers have indicated very high background sources in the Neuse River basin (Paerl, 1987; Spruill and

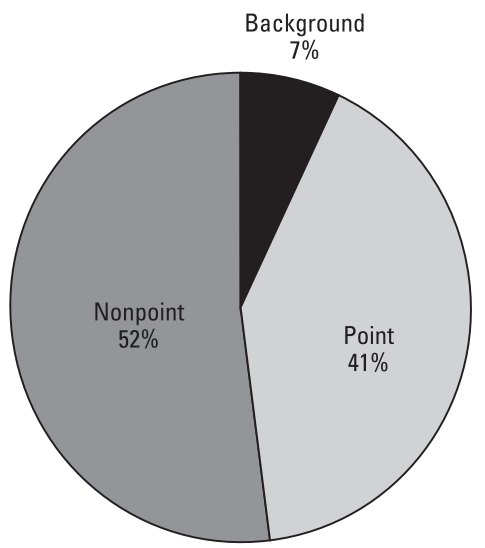

Figure 31. Sources of total phosphorus delivered to the Neuse River estuary at New Bern, North Carolina, in calendar year 2000. 
others, 1998; North Carolina Department of Environment and Natural Resources, 2001), and yet the estimated background load in this study yielded only 7 percent of the total delivered phosphorus load to the Neuse River estuary (fig. 31).

There are several reasons for the apparent discrepancy between what the available data indicate with respect to background phosphorus (only 7 percent of the total phosphorus load to the Neuse River estuary) and what previous researchers have reported with respect to background, such as high ambient concentrations (Paerl, 1987) and high phosphorus from geologic sources (Spruill and others, 1998). In general, however, the primary reason for this apparent discrepancy is that the sources of phosphorus are not particularly well understood and defined with respect to time, space, and scale or landscape position in a watershed in the nutrient-source accounting process. For example, where ground water discharges to a stream and is a source of phosphorus, the origin of the phosphorus must be determined - is it an anthropogenic source, such as derived from the land surface from some anthropogenic activity and transported to the water table and then discharged to surface water; or a background source, such as directly discharged from an unconfined or confined aquifer with phosphorus-containing matrix material; or simply transported into surface water by ground water flowing through recent fluvial streambed deposits that have been eroded from uplands as part of some anthropogenic activity (farming) and then deposited in the streambed?

Some clues to the answer to the above question can be obtained from work conducted for this study at the Lizzie Research Station and from previous work. Spruill and others (1998) indicated geologic sources of phosphorus in the Neuse and Tar-Pamlico basins as evidenced by elevated phosphorus concentrations $(0.1 \mathrm{mg} / \mathrm{L})$ that are not reflected in the phosphorus concentration data reported for small streams by Simmons and Heath (1982) or Smith and others (2003). Spruill and others (1998) reported a significant correlation between ground-water and surface-water concentrations of dissolved phosphorus in coastal plain streams, indicating that phosphorus most likely was derived either from the bed material of streams or from aquifer material from which ground water is discharged. If the phosphorus were contained in water from a confined aquifer, such as the Yorktown (table 3 ) with water ages of greater than 30-50 years, it is likely that the age of the streamwater would reflect the ground-water contribution from this source. Using silica data, the median age of water from the larger streams at the Lizzie Research Station site, Sandy Run and Middle Swamp (fig. 16), was determined to be less than 5 years, which indicates very little contribution of ground water by the confined aquifer and no geologic source. Therefore, the relatively young age of water in Sandy Run and Middle Swamp indicates discharge of young ground water through bed material that contains phosphorus, derived either from decomposing vegetation and(or) from sediment eroded from uplands. As described in Spruill (2000), phosphorus on the bed material can be deposited as a result of sediment containing high phosphorus concentrations eroded from uplands and then released by organic carbon-rich (1-25 mg/L, table 3), oxygen-deficient (generally less than $0.3 \mathrm{mg} / \mathrm{L}$, table 3 ), geochemically reducing ground water as it passes through the streambed sediments and riparian areas before discharging to the stream. In addition, reducing conditions that occur in the streams in the Little Contentnea watershed during the summer low-flow periods, which tend to reduce nitrate (fig. 14), are the same conditions that can chemically liberate phosphorus.

Effects of cultural eutrophication with respect to phosphorus enrichment in coastal plain streams of the Neuse River basin are much greater than for nitrogen. The ELI range for phosphorus was 2-12 times with values typically 5-6 times the estimated background yield for second- and higher-order streams. The ELI range for total nitrogen was $1-5$, with values typically about 2 times the estimated background yield. This finding contrasts with those of Smith and others (2003) that enrichment from background with respect to nitrogen was generally greater (6.4) than for phosphorus (2.0). The nitrogen and phosphorus enrichment reported here is in agreement with Simmons and Heath (1982), who found that agricultural streams in North Carolina had 2-13 times the baseline concentrations of phosphorus during stormflow conditions compared to 1-5 times baseline concentrations for total nitrogen.

The higher ELI for phosphorus relative to nitrogen in the Neuse River basin may be because phosphorus is closely associated with sediment (Schlesinger, 1997) and because sediment erosion rates in many areas are substantially higher today than a few centuries ago as a result of clearing of vegetation for agriculture and development (Pimentel and others, 1995). A possible reason that phosphorus yields are higher than nitrogen yields compared to background yields in the Neuse River basin is again provided by process-oriented studies conducted at the Lizzie Research Station. Oxidationreduction (redox) conditions in bed sediment and riparian zones along rivers that tend to reduce oxidized chemical species in ground water, such as nitrate, that result from farming practices and discharge to streams are the same processes that can mobilize phosphorus. Thus, denitrification, which takes place in the streambed sediments prior to ground water discharging to the stream, is a natural mechanism that can reduce nitrogen loading by converting part of the nitrogen, as nitrate, to nitrogen gas (fig. 17).

The loading rate for phosphorus in the Neuse River basin is greatest in the upper Neuse estuary, where potential effects on algal growth are substantial. Based on data presented in Qian and others (2000), phosphorus concentrations remain near $0.2 \mathrm{mg} / \mathrm{L}$ at three stations in the upper Neuse estuary just above and below New Bern, N.C. Although both phosphorus and nitrogen concentrations have declined throughout much of the Neuse basin since 1990 (Qian and others, 2000), phosphorus declines are less evident near New Bern; nevertheless, Qian and others (2000) concluded that the upper estuary has shifted to phosphorus limitation. High loading rates for phosphorus from Swift Creek near Streets Ferry and Trent River near Trenton, however, during the summer months could sustain phosphorus 
concentrations in the upper Neuse estuary, thus favoring nitrogen limitation.

While management actions to control nitrogen throughout the basin may help in controlling nuisance algal blooms and fish kills under average hydrologic conditions, large amounts of nitrogen moving into the estuary as a result of extreme events, such as during hurricanes or extended wet periods, may cause algal growths of much greater severity than would occur if phosphorus discharges from Swift Creek and the Trent River were lower. This is because the potential for algal growth is greater as more phosphorus is available — a pound of phosphorus has the potential for producing as much as 77 pounds of algal cells (Lamb, 1985). Thus, if $0.1 \mathrm{mg} / \mathrm{L}$ of phosphorus is available, $7.7 \mathrm{mg} / \mathrm{L}$ of algal biomass may be produced if nitrogen is not limiting. It becomes even more important to control phosphorus sources if phosphorus is the growth-limiting nutrient. At any rate, this potential problem warrants further investigation into the cause of high phosphorus concentrations in the Neuse River at New Bern, N.C., and consideration for managing phosphorus loads into the estuary. Such a study could result in findings to support application of management techniques to control phosphorus that could substantially improve water quality and have long-term benefits for the Neuse River estuary.

Evidence from this study indicates that most of the water in second- and higher-order streams is apparently composed of relatively young water, as determined by the evaluations of tritium and silica data (fig. 16), and that most of the base flow in the basin is derived from ground water in alluvial aquifers located in riparian areas adjacent to streams. Therefore, a logical method for preventing nonpoint-source contaminants from entering streams would be to limit or prevent development within riparian corridors along streams. Alluvial aquifers in riparian areas appear to be the source of most of the water in the Neuse River and its larger tributaries, and any activities along river terraces and riparian areas that could be a source of nutrients (particularly nitrate) or other contaminants are more likely to affect the water quality of the receiving stream. The actual widths of riparian areas required to minimize nitrate contamination from nonpoint sources could be determined by incorporating estimates of ground-water velocities toward the discharge points during wet periods, nitrogen loading rates to fields, and estimated rates of denitrification derived from field studies in different hydrologic settings. In addition, because very little nitrogen loss takes place in larger streams (Alexander and others, 2000) and because point-source discharges of nitrogen and phosphorus are a significant part of the anthropogenic load in the Neuse River (greater than 30 percent according to North Carolina Department of Environment and Natural Resources, 2001), substantial improvements in water quality in the Neuse River could be made by identifying discharge points that have major effects on river water quality and by improving wastewater-treatment capabilities of the discharge facilities.

\section{Summary and Conclusions}

Chemical, geologic, hydrologic, and age-dating information collected from 1999 to 2002 was used to examine the transport of contaminants, primarily nitrogen, in ground water and their pathways to surface water in a coastal plain setting in the southeastern United States - the Lizzie Research Station near Lizzie, N.C. Data were collected from more than 35 wells and 4 surface-water sampling sites located in a $0.59-\mathrm{mi}^{2}$ basin to examine detailed hydrogeology and geochemical processes affecting nutrient fate and transport. Two additional surface-water sampling sites were located downstream from the primary study site to evaluate basin-scale effects. Chemical and flow data also were collected at an additional 10 sites in the Coastal Plain portion of the Neuse River basin between Kinston and New Bern, N.C., to evaluate loads transported in the Neuse River and primary tributary basins.

At the Lizzie Research Station site, horizontal flow is induced by the presence of a confining unit at shallow depth. Age-dating, chemical, and piezometric data all indicate flow from the surficial and alluvial aquifers as the dominant source of ground water to streamflow. In the uplands, the upper several feet of saturated thickness of the surficial aquifer is the only zone in which nitrate is stable. Denitrification in deeper parts of the aquifer and in the riparian zones is indicated by a characterization of redox conditions in the aquifer and by the presence of excess levels of nitrogen. Direct ground-water discharge of nitrate to surface water during base-flow conditions is unlikely to be significant because of strongly reducing conditions in the riparian zones of the streams. Instantaneous nitrate loads from a drainage tile at the Lizzie Research Station study site may account for much of the nitrate load in the receiving stream, which suggests that artificial drainage is a major source of nutrients from ground water to this stream. During base-flow conditions, when these artificial drainages are not flowing, it is hypothesized that the mineralization of organic matter on the streambed is a major source of nitrate and(or) ammonium in the stream. Base flow is only a small contributing factor to loads, because both flow and inorganic nitrogen concentrations are low.

The use of sprayed swine wastes on fields planted in crops at the Lizzie Research Station study site resulted in increased concentrations of nitrate and other chemical constituents in ground water beneath spray fields compared to ground water beneath crops treated with commercial fertilizer. No change in dissolved phosphorus concentrations was observed in ground water beneath the spray field, and no phosphorus concentration 
exceeded $0.02 \mathrm{mg} / \mathrm{L}$, which indicates that phosphorus is primarily adsorbed in the soil matrix prior to reaching shallow ground water. The nitrate concentration in ground water from the spray field well increased by a factor of 3.5 after 4 years of spray applications. Nitrate concentrations ranged from 10 to $35 \mathrm{mg} / \mathrm{L}$, and one concentration as high as $56 \mathrm{mg} / \mathrm{L}$ was observed in water from this well in spring 2002. Overapplication of swine wastes is a possible cause of elevated nitrate concentrations in ground water and the tile drainage beneath fields in the study area.

Based on published data about background concentrations, nitrogen and phosphorus concentrations in the Neuse River basin, and discharge data collected in calendar years 2000 and 2001 , nitrogen yields in the Neuse River basin typically were about two times background yields at most sites in the study area. Phosphorus yields typically were six times higher than background yields, which indicates that phosphorus pollution from human activities generally is more pronounced in the Neuse River basin. A possible reason for this is that conditions are favorable for denitrification in coastal plain watersheds, and reducing conditions in the bed and riparian areas of the study streams are favorable for mobilizing phosphorus from decomposing vegetation or from eroding sediment from uplands that then is deposited.

Data from this study indicate that anthropogenic effects on nitrogen yields were greatest in first-order streams (yields were greater than 2 tons $/ \mathrm{mi}^{2}$ ), and 1 ton $/ \mathrm{mi}^{2}$ or less in second- and higher-order streams in the Little Contentnea Creek subbasin. Nitrogen yields in the Contentnea Creek subbasin ranged from 0.59 to 2 tons $/ \mathrm{mi}^{2}$, with typical yields of approximately $1 \mathrm{ton} / \mathrm{mi}^{2}$. Contentnea Creek near Evansdale had the highest yield $\left(2\right.$ tons $\left./ \mathrm{mi}^{2}\right)$, indicating that a major source of nitrogen is upstream from this station. Nitrogen yields were lower at Contentnea Creek at Hookerton in 2000 and 2001 compared to previous yield estimates based on 1990 data. Along the main stem of the Neuse River, nitrogen yields during 2000 and 2001 ranged from 3.4 tons $/ \mathrm{mi}^{2}$ in Bear Creek, a tributary west of Kinston, N.C., to 0.55 ton/ $/ \mathrm{mi}^{2}$ in the Trent River.

Annual phosphorus yields in the Little Contentnea Creek subbasin for 2000 and 2001 ranged from 0.02 to about $0.15 \mathrm{ton} / \mathrm{mi}^{2}$. In contrast with total nitrogen yields, the larger total phosphorus yields were in higher-order streams (about three times greater), indicating either that the major source of phosphorus in the Little Contentnea Creek subbasin originates in the larger streams or the phosphorus is deposited by sediment eroded from low-order headwater streams and deposited on the bed. Phosphorus yields in the Contentnea Creek subbasin ranged from 0.02 to $0.12 \mathrm{ton} / \mathrm{mi}^{2}$. Contentnea Creek at Hookerton had the highest phosphorus yield observed in the subbasin, about five to six times the expected background yield, although yields for phosphorus reported for 2000 and 2001 for Contentnea Creek at Hookerton were considerably lower than those reported for 1990. Phosphorus yields in the Neuse River basin ranged from 0.02 to $0.29 \mathrm{ton} / \mathrm{mi}^{2}$, with the highest yields occurring near New Bern in the vicinity of the upper Neuse estuary.

The total nitrogen load delivered to the Neuse estuary in 2000 was 4,807 tons or 9.61 million pounds, and the total phosphorus load was 425 tons or 850,000 pounds. It is estimated that about 17 percent (1,630,000 pounds) of the delivered total nitrogen load is from background sources, based on the background total nitrogen concentration of $0.50 \mathrm{mg} / \mathrm{L}$ used in this analysis. This background estimate is larger than the 8.6 percent ( 830,000 pounds) background total nitrogen load reported by the North Carolina Department of Environment and Natural Resources for 1995, but less than the 30 percent estimated by the USGS spatially referenced regression on watershed model for 1992. The average total nitrogen load, based on data from Fort Barnwell, Trent River, and wastewatertreatment plants below Fort Barnwell and delivered to the Neuse estuary was 9.65 million pounds for the base period (1991-95). The total nitrogen load of 9.61 million pounds reported in this study for calendar year 2000 is comparable to the base period total nitrogen load.

The total phosphorus load transported to the Neuse estuary in 2000 was 425 tons. No recently published information was found on total point-source contributions of phosphorus to the Neuse River at Fort Barnwell for this study; therefore, general estimates from past studies were used. Based on this analysis, about 7 percent of the total phosphorus load in 2000 was from background sources, and about 93 percent of the total phosphorus load was derived from anthropogenic point (41 percent) and nonpoint (52 percent) sources.

Effects of cultural eutrophication with respect to phosphorus enrichment in coastal plain streams of the Neuse River basin are much greater than for nitrogen. The eutrophication loading index for phosphorus ranged between 2 and 12 times, and values typically were 5 to 6 times the estimated background yield for second- and higher-order streams compared to the eutrophication loading index range for total nitrogen of 1 to 5 times, and values typically were about 2 times the estimated background yield. This finding is in agreement with nutrient enrichment previously reported for agricultural streams, but contrasts with recent (Smith and others, 2003) findings that nutrient enrichment from background sources generally was greater for nitrogen (6.4) than for phosphorus (2.0) in streams throughout the United States. One possible reason why this occurs in the Neuse River basin is provided by process-oriented studies conducted at the Lizzie Research Station. Redox conditions in bed sediment and riparian zones along rivers that tend to reduce oxidized forms of nitrate as it moves from recharge to discharge areas near streams are the same conditions that can mobilize phosphorus from bed sediments and maintain elevated concentrations in streamwaters in the Coastal Plain. Thus, the reducing conditions in streams in the Neuse River basin tend to 
exacerbate anthropogenic effects of phosphorus release and mitigate effects of nitrogen release into the environment.

The potential loading rate in the Neuse River basin for phosphorus is greatest in the upper Neuse estuary, where effects of nutrients on algal growth can be substantial. The high yields of phosphorus from Swift Creek near Streets Ferry and Trent River near Trenton may be one important reason that the upper Neuse estuary is often nitrogen limited. While management actions to control nitrogen throughout the basin likely help in controlling nuisance algal blooms and fish kills under average conditions, large amounts of nitrogen moving into the estuary as a result of extreme events may potentially cause algal growths of much greater severity than would occur if phosphorus discharges from Swift Creek and the Trent River were lower. Determining the sources of elevated phosphorus concentrations in these two tributary streams warrants further investigation that could result in application of management techniques that can have substantial water-quality improvement benefits for the Neuse River estuary.

\section{References Cited}

Alexander, R.B., Smith, R.A., and Schwarz, G.E., 2000, Effect of stream channel size on the delivery of nitrogen to the Gulf of Mexico: Nature, v. 403, p. 758-761.

Baker, J.L., and Johnson, H.P., 1981, Nitrate-nitrogen in tile drainage as affected by fertilization: Journal of Environmental Quality, v. 10, p. 519-522.

Böhlke, J.K., and Denver, J.M., 1995, Combined use of groundwater dating, chemical, and isotopic analyses to resolve the history and fate of nitrate contamination in two agricultural watersheds, Atlantic Coastal Plain, Maryland: Water Resources Research, v. 31, no. 9, p. 2319-2339.

Brenton, R.W., and Arnett, T.L., 1993, Methods of analysis by the U.S. Geological Survey National Water Quality Laboratory-Determination of dissolved organic carbon by UV-promoted persulfate oxidation and infrared spectrometry: U.S. Geological Survey Open-File Report 92-480, 12 p.

Burkholder, J.M., and Glasgow, H.B., Jr., 1997, Pfiesteria piscicida and other Pfiesteria-like dinoflagellatesBehavior, impacts and environmental controls: Limnology and Oceanography, v. 42, p. 1052-1075.

Burkholder, J.M., Glasgow, H.B., Jr., and Hobbs, C.W., 1995, Distribution and environmental conditions for fish kills linked to a toxic ambush predator dinoflegellate: Marine Ecology Progress Series, v. 124, p. 43-61.
Burkholder, JoAnn, Glasgow, Howard, Melia, Greg, Kinder, Carol, and Reed, Robert, 2004, Water quality impairment in the Neuse estuary from nutrient loading —Progress and ongoing challenges: Raleigh, Water Resources Research Institute of The University of North Carolina, 2004 Annual Conference, March 31, 2004, Raleigh, N.C., available online at http://www2.ncsu.edu/ncsu/CIL/WRRI/ 2004_annual_conference.html.

Busenberg, Eurybiades, and Plummer, L.N., 1992, Use of chlorofluorocarbons $\left(\mathrm{CCl}_{3} \mathrm{~F}\right.$ and $\left.\mathrm{CCl}_{2} \mathrm{~F}_{2}\right)$ as hydrologic tracers and age-dating tools-The alluvium and terrace system of central Oklahoma: Water Resources Research, v. 28 , no. 9, p. 2257-2283.

Busenberg, Eurybiades, Weeks, E.P., Plummer, L.N., and Bartholomay, R.C., 1993, Age dating ground water by use of chlorofluorocarbons $\left(\mathrm{CCl}_{3} \mathrm{~F}\right.$ and $\left.\mathrm{CCl}_{2} \mathrm{~F}_{2}\right)$, and distribution of chlorofluorocarbons in the unsaturated zone, Snake River Plain aquifer, Idaho National Engineering Laboratory, Idaho: U.S. Geological Survey Water-Resources Investigations Report 93-4054, 47 p.

Caldwell,W.S., 1992, Selected water-quality and biological characteristics of streams in some forested basins of North Carolina, 1985-88: U.S. Geological Survey WaterResources Investigations Report 92-4129, 114 p.

Chapelle, F.H., McMahon, P.B., Dubrovsky, N.M., Fujii, R.F., Oaksford, E.T., and Vroblesky, D.A., 1995, Deducing the distribution of terminal electron accepting processes in hydrologically diverse groundwater systems: Water Resources Research, v. 31, p. 359-371.

Chatterjee, Samprit, and McLeish, D.L., 1986, Fitting linear regression models to censored data by least squares and maximum likelihood methods: Communications in Statistics-Theory and Methods, v. 15, no. 11, p. 3227-3243.

Cohn, T.A., Delong, L.L., Gilroy, E.J., Hirsch, R.M., and Wells, D.K., 1989, Estimating constituent loads: Water Resources Research, v. 25, no. 5, p. 937-942.

Conover, W.J., 1980, Practical nonparametric statistics: New York, John Wiley \& Sons, 493 p.

Crawford, C.G., 1991, Estimation of suspended-sediment rating curves and mean suspended-sediment loads: Journal of Hydrology, v. 129, p. 331-348.

Crawford, C.G., 1996, Estimating mean constituent loads in rivers by the rating-curve and flow-duration, rating-curve methods: Bloomington, Indiana University, Ph. D. dissertation, $245 \mathrm{p}$.

Crawford, J.K., 1985, Water quality of North Carolina streams-Water-quality characteristics of selected sites on the Cape Fear River, North Carolina, 1955-80_-Variability, loads, and trends of selected constituents: U.S. Geological Survey Water-Supply Paper 2185-F, 44 p. 
Daniels, R.B., and Kane, E.O., 2001, Coastal Plain scarps of the Neuse River basin, North Carolina as delineated by R.B. Daniels: Raleigh, North Carolina Department of Environment and Natural Resources, Ground Water Circular $18,18 \mathrm{p}$.

Dempster, A.P., Laird, N.M., and Rubin, D.B., 1977, Maximum likelihood from incomplete data via the EM algorithm: Journal of the Royal Statistical Society, Series B, v. 39, no. 1, p. 1-22.

Dodd, R.C., McMahon, Gerard, and Stichter, S.J., 1992, Watershed planning in the Albemarle-Pamlico estuarine system, report 1-Annual average nutrient budgets: North Carolina Department of Environment, Health, and Natural Resources, Albemarle-Pamlico Estuarine Study Report No. 92-10, 116 p.

Duff, J.H., and Triska, F.J., 2000, Nitrogen biogeochemistry and surface-subsurface exchange in streams, in Jones, J.B., and Mulholland, P.J., eds., Streams and ground waters: New York, Academic Press, p. 197-210.

Dunkle, S.A., Plummer, L.N., Busenberg, Eurybiades, Phillips, P.J., Denver, J.M., Hamilton, P.A., Michel, R.L., and Coplen, T.B., 1993, Chlorofluorocarbons $\left(\mathrm{CCl}_{3} \mathrm{~F}\right.$ and $\mathrm{CCl}_{2} \mathrm{~F}_{2}$ ) as dating tools and hydrologic tracers in shallow groundwater of the Delmarva Peninsula, Atlantic Coastal Plain, United States: Water Resources Research, v. 29, p. 3837-3860.

Efron, Bradley, 1982, The jackknife, the bootstrap and other resampling plans: Philadelphia, Pa., Society for Industrial and Applied Mathematics, $92 \mathrm{p}$.

Evans, R.O., Westerman, P.W., and Overcash, M.R., 1984, Subsurface drainage water quality from land application of swine lagoon effluent: Transactions of the American Society of Agricultural Engineers, v. 27, no. 2, p. 473-478.

Farrell, K.M., Mew, H.E., Jr., Keyworth, A.J., and Clark, T.W., 2003, Comprehensive landscape analysis, geomorphology, and sequence stratigraphy in eastern North Carolina's Little Contentnea Creek watershed of the Neuse River basin-Methods for constructing reconnaissance-level geologic maps of a relic Plio-Pleistocene terrane in Farrell, K.M., and Keyworth, A.J., eds., Surficial geology and shallow aquifer system of the Little Contentnea Creek watershed, Neuse River basin, North Carolina: Carolina Geological Society Annual Field Trip, November 14-16, 2003, 56 p.

Fishman, M.J., and Friedman, L.C., eds., 1989, Methods for determination of inorganic substances in water and fluvial sediments: U.S. Geological Survey Techniques of WaterResources Investigations, book 5, chap. A1, 545 p.

Gilroy, E.J., Hirsch, R.M., and Cohn, T.A., 1990, Mean square error of regression-based constituent transport estimates: Water Resources Research, v. 26, p. 2069-2077.
Glasgow, H.B., and Burkholder, J.M., 2000, Water quality trends and management implications from a five-year study of a eutrophic estuary: Ecological Applications, v. 10, p. 1024-1046.

Hallberg, G.R., 1989, Nitrate in ground water in the United States, in Follett, R.F., ed., Nitrogen management and ground water protection: Amsterdam, Elsevier, p. 35-74.

Harden, S.L., and Spruill, T.B., 2004, Ionic composition and nitrate in drainage water from fields fertilized with different nitrogen sources, Middle Swamp watershed, North Carolina, August 2000-August 2001: U.S. Geological Survey Scientific Investigations Report 2004-5123, 14 p.

Harned, D.A., 1982, Water quality of the Neuse River, North Carolina_-Variability, pollution loads, and long-term trends: U.S. Geological Survey Water-Supply Paper 2185-D, $44 \mathrm{p}$.

Harned, D.A., 2003, Water-quality trends in the Neuse River basin, North Carolina, 1974-2003: American Geophysical Union, Eos, Transactions, 2003 Fall Meeting Supplement, v. 84, no. 46, abstract H41F-1048.

Harned, D.A., McMahon, Gerard, Spruill, T.B., and Woodside, M.D., 1995, Water-quality assessment of the AlbemarlePamlico drainage basin, North Carolina and VirginiaCharacterization of suspended sediment, nutrients, and pesticides: U.S. Geological Survey Open-File Report 95-191, $131 \mathrm{p}$.

Haven, W.T., 2003, Introduction to the North Carolina ground water recharge map: Raleigh, North Carolina Department of Environment and Natural Resources, Division of Water Quality, Groundwater Section, Ground Water Circular 19.

Heaton, T.H.E., and Vogel, J.C., 1981, "Excess air" in groundwater: Journal of Hydrology, v. 50, p. 201-216.

Jaynes, D.B., Colvin, T.S., Karlen, D.L.,Cambardella, C.A., and Meek, D.W., 2001, Nitrate loss in subsurface drainage as affected by nitrogen fertilizer rate: Journal of Environmental Quality, v. 30, p. 1305-1314.

Johnston, J.J., Novak, J.H., and Kraemer, S.R., 2000, Multimedia integrated modeling for environmental protection-Introduction to a collaborative framework: Environmental Monitoring and Assessment, v. 63, p. 253-263.

Karr, J.D., Showers, W.J., Gilliam, J.W., and Andres, A.S., 2001, Tracing nitrate transport and environmental impact from intensive swine farming using delta nitrogen-15: Journal of Environmental Quality, v. 30, p. 1163-1175.

Korom, S.F., 1992, Natural denitrification in the saturated zone-A review: Water Resources Research, v. 28, p. 1657-1668. 
Koterba, M.T., Wilde, F.D., and Lapham, W.W., 1995, Groundwater data-collection protocols and procedures for the National Water-Quality Assessment Program-Collection and documentation of water-quality samples and related data: U.S. Geological Survey Open-File Report 95-399, 113 p.

Lamb, J.C., 1985, Water quality and its control: New York, John Wiley \& Sons, 384 p.

Likes, Jiri, 1980, Variance of the MVUE for lognormal variance: Technometrics, v. 22, no. 2, p. 253-258.

Mallin, M.A., 2000, Impacts of animal production on rivers and estuaries: American Scientist, v. 88, no. 1, p. 26-37.

McMahon, Gerard, Alexander, R.B., and Song, Qian, 2003, Support of total maximum daily load programs using spatially referenced regression models: Journal of Water Resources Planning and Management, v. 129, issue 4, p. 315-329.

McMahon, Gerard, and Lloyd, O.B., Jr., 1995, Water-quality assessment of the Albemarle-Pamlico drainage basin, North Carolina and Virginia-Environmental setting and waterquality issues: U.S. Geological Survey Open-File Report 95-136, $72 \mathrm{p}$.

McMahon, Gerard, and Woodside, M.D., 1997, Nutrient mass balance for the Albemarle-Pamlico drainage basin, North Carolina and Virginia, 1990: Journal of the American Water Resources Association, v. 33, no. 3, p. 573-589.

North Carolina Department of Environment and Natural Resources, 1999, Total maximum daily load for total nitrogen to the Neuse River estuary, North Carolina, Draft: North Carolina Department of Environment and Natural Resources, Division of Water Quality, $49 \mathrm{p}$.

North Carolina Department of Environment and Natural Resources, 2001, Phase II of the total maximum daily load for total nitrogen to the Neuse River estuary, North Carolina, Final: Raleigh, North Carolina Department of Environment and Natural Resources, Division of Water Quality, $57 \mathrm{p}$.

North Carolina State University, 1992, North Carolina agricultural chemicals manual: Raleigh, North Carolina State University College of Agriculture and Life Sciences, $355 \mathrm{p}$.

North Carolina State University, 2003, North Carolina agricultural chemicals manual: Raleigh, North Carolina State University College of Agriculture and Life Sciences.

North Carolina State University, 2004, RiverNet: accessed October 6, 2004, at http://rivernet.ncsu.edu/sites.html .

Paerl, H.W., 1987, Dynamics of blue-green algal blooms in the lower Neuse River, North Carolina-Causative factors and potential controls: Raleigh, Water Resources Research Institute of The University of North Carolina, Report No. 229, 187 p.

Paerl, H.W., Mallin, M.A., Donahue, C.A., Go, Malia, and Peierls, B.L., 1995, Nitrogen loading sources and eutrophication of the Neuse River estuary, North Carolina-Direct and indirect roles of atmospheric deposition: Raleigh, Water Resources Research Institute of The University of North Carolina, Report No. 291, 119 p.
Paerl, H.W., Pinckney, J.L., Fear, J.M., and Peierls, B.L., 1998, Ecosystem responses to internal and watershed organic matter loading-Consequences for hypoxia in the eutrophying Neuse River estuary, North Carolina, USA: Marine Ecology Progress Series, v. 166, p. 17-25.

Pimentel, D., Harvey, C., Resosudarmo, P., Sinclair, K., Kurz, D., McNair, M., Crist, S., Shpritz, L., Fitton, L., Saffouri, R., and Blair, R., 1995, Environmental and economic costs of soil erosion and conservation benefits: Science, v. 267, p. 1117-1123.

Pinckney, J.L., Millie, D.F., Vinyard, B.T., and Paerl, H.W., 1997, Environmental controls on phytoplankton bloom dynamics in the Neuse River estuary, USA: Canadian Journal of Fisheries and Aquatic Sciences, v. 54, p. 2491-2501.

Qian, S.S., Borsuk, M.E., and Stow, C.A., 2000, Seasonal and long-term nutrient trend decomposition along a spatial gradient in the Neuse River watershed: Environmental Science and Technology, v. 34, p. 4474-4482.

Ragland, B.C., Walters, D.A., Cartano, G.D., and Taylor, J.E., 2003, Water resources data, North Carolina, water year 2002, v. 1A-Surface-water records: U.S. Geological Survey Water-Data Report NC-02-1A, 534 p.

Randall, G.W., Iragavarapu, T.K., and Schmitt, M.A., 2000, Nutrient losses in subsurface drainage water from dairy manure and urea applied for corn: Journal of Environmental Quality, v. 29, p. 1244-1252.

Richards, R.P., 1997, Estimation of pollutant loads in rivers and streams-A guidance document for NPS programs: Tiffin, Ohio, Heidelberg College, Water Quality Laboratory, 80 p.

Scanlon, T.M., Raffensberger, J.P., and Hornberger, G.M., 2001, Modeling transport of dissolved silica in a forested headwater catchment-Implications for defining the hydrochemical response of observed flow pathways, Water Resources Research, v. 37, p. 1071-1082.

Schlesinger, W.H., 1997, Biogeochemistry-An analysis of global change: San Diego, Academic Press, 588 p.

Simmons, C.E., and Heath, R.C., 1982, Water-quality characteristics of streams in rural and forested areas of North Carolina: U.S. Geological Survey Water-Supply Paper 2185-B, 33 p.

Smith, D.G., George, E.D., and Breton, P.L., 1996, Water resources data, North Carolina, water year 1995, groundwater records: U.S. Geological Survey Water-Data Report NC-95-2, 273 p.

Smith, J.T., and Evans, R.O., 1998, Evaluation of BMPs to improve drainage water quality from agricultural land irrigated with swine lagoon effluent, in Brown, L.C., ed., Drainage in the 21st century-Food production and the environment, Proceedings of the 7th International Drainage Symposium: American Society of Agricultural Engineers, p. 9-16.

Smith, R.A., Alexander, R.B., and Scwharz, G.A., 2003, Natural background concentrations of nutrients in streams and rivers of the conterminous United States: Environmental Science and Technology, v. 37, no. 14, 3039-3047. 
Spaulding, R.F., and Exner, M.E., 1993, Occurrence of nitrate in groundwater-A review: Journal of Environmental Quality, v. 22, p. 392-402.

Spruill, T.B., 2000, Statistical evaluation of effects of riparian buffers on nitrate and ground-water quality: Journal of Environmental Quality, v. 29, no. 5, p. 1523-1538.

Spruill, T.B., Harned, D.A., Ruhl, P.A., Eimers, J.L., McMahon, Gerard, Smith, K.E., Galeone, D.R., and Woodside, M.D., 1998, Water quality in the AlbemarlePamlico drainage basin, North Carolina and Virginia, 1992-95: U.S. Geological Survey Circular 1157, $36 \mathrm{p}$.

Spruill, T.B., Showers, W.L., and Howe, S.S., 2002, Application of classification-tree methods to identify nitrate sources in ground water: Journal of Environmental Quality, v. 31, no. 5, p. 1538-1549.

Spruill, T.B., Woodside, M.D., Harned, D.A., McMahon, Gerard, and Eimers, J.L., 1996, Results of the AlbemarlePamlico drainage NAWQA-Nutrients and pesticides in surface water and ground water, Proceedings, SolutionsA Technical Conference on Water Quality: Raleigh, North Carolina State University, March 19-21, 1996, p. 24-30.

Stanley, D.W., 1989, Historical trends in land use, nutrient production, water quality and fisheries in the AlbemarlePamlico estuarine system: Greenville, N.C., East Carolina University, Institute for Coastal and Marine Resources.

Stephenson, L.W., and Johnson, B.L., 1912, The water resources of the Coastal Plain of North Carolina, in Clark, W.B., and others, 1912, The Coastal Plain of North Carolina: North Carolina Geological and Economic Survey, v. III, pt. II, p. 333-483.

Stow, C.A., and Borsuk, M.E., 2003, Assessing TMDL effectiveness using flow-adjusted concentrations-A case study of the Neuse River, North Carolina: Environmental Science and Technology, v. 37, p. 2043-2050.

Strahler, A.N., 1963, The earth sciences: New York, Harper and Row, $681 \mathrm{p}$.

Tedder, S.W., Sauber, J., Ausley, J., and Mitchell, S., 1980, Working paper-Neuse River investigation 1979: Raleigh, North Carolina Department of Natural Resources and Community Development, Division of Environmental Management.
Tesoriero, A.J., Liebscher, H., and Cox, S.E., 2000, The mechanism and rate of denitrification in an agricultural watershed-Electron and mass balance along ground water flow paths: Water Resources Research, v. 36, no. 6, p. $1545-1559$.

Tesoriero, A.J., Spruill, T.B., Mew, H.E., Jr., Farrell, K.M., and Harden, S.L., 2005, Nitrogen transport and transformations in a Coastal Plain watershed-Influence of geomorphology on flow paths and residence times: Water Resources Research, v. 41, W02008, doi:10.1029/2003WR002953 [15 p.].

U.S. Department of Agriculture, Natural Resources Conservation Service, 2002, National soil survey handbook, title 430-VI, accessed November 12, 2004, at http://soils.usda.gov/technical/handbook/.

U.S. Environmental Protection Agency and U.S. Department of Agriculture, 1998, Clean water action plan-Restoring and protecting America's waters: U.S. Environmental Protection Agency and U.S. Department of Agriculture, 89 p.

U.S. Geological Survey, 1999-2002, Water resources data, North Carolina, water years 1999-2002: U.S. Geological Survey Water-Data Reports NC-XX-1A, 1B, and NC-XX-2, [independently paged volumes for each year].

U.S. Geological Survey, 2004, NWISWeb data for North Carolina, accessed October 21, 2004, at http://nc.waterdata.usgs.gov/nc/nwis .

Wilde, F.D., Radtke, D.B., Gibs, J., and Iwatsubo, R.T., 1998, National field manual for the collection of water-quality data: U.S. Geological Survey Techniques of Water-Resources Investigations, book 9, variously paged.

Winner, M.D., Jr., and Coble, R.W., 1996, Hydrogeologic framework of the North Carolina Coastal Plain, in Regional Aquifer-System Analysis-Northern Atlantic Coastal Plain: U.S. Geological Survey Professional Paper 1404-I, 106 p. +14 pls.

Wolynetz, M.S., 1979, Algorithm 139-Maximum likelihood estimation in a linear model with confined and censored data: Applied Statistics, v. 28, p. 195-206.

Woodside, M.D., and Simerl, B.R., 1995, Land use and nutrient concentrations and yields in selected streams in the Albemarle-Pamlico drainage basin, North Carolina and Virginia: U.S. Geological Survey Open-File Report 95-457, 4 p. 
52 Nitrogen Transport at a Confined Animal Feeding Operation in an Agricultural Watershed in the Neuse River Basin, 1999-2002 


\section{Appendix Tables}

1. Data available for stations included in the Lizzie Research Station study.

2. Ninety-five percent confidence intervals for annual loads and methods of load estimation used in the Lizzie Research Station study. 
Appendix table 1. Data available for stations included in the Lizzie Research Station study.

\begin{tabular}{|c|c|c|}
\hline Site number & Station name & Web address \\
\hline 0208925200 & Bear Creek at Mays Store & http://waterdata.usgs.gov/nc/nwis/inventory/?site_no $=0208925200$ \\
\hline 0209173190 & Unnamed tributary to Sandy Run near Lizzie & http://waterdata.usgs.gov/nc/nwis/inventory/?site_no=0209173190 \\
\hline 0209173200 & Sandy Run near Lizzie & http://waterdata.usgs.gov/nc/nwis/inventory/?site_no=0209173200 \\
\hline 02091740 & Little Contentnea at Scuffleton & http://waterdata.usgs.gov/nc/nwis/inventory/?site_no=02091740 \\
\hline 02090380 & Contentnea Creek near Lucama & http://waterdata.usgs.gov/nc/nwis/inventory/?site_no=02090380 \\
\hline 02090519 & Contentnea Creek near Evansdale & http://waterdata.usgs.gov/nc/nwis/inventory/?site_no=02090519 \\
\hline 02091500 & Contentnea Creek at Hookerton & http://waterdata.usgs.gov/nc/nwis/inventory/?site_no=02091500 \\
\hline 02091000 & Nahunta Swamp near Shine & http://waterdata.usgs.gov/nc/nwis/inventory/?site_no=02091000 \\
\hline \multicolumn{3}{|c|}{ Weather station } \\
\hline 0209173196 & S1 Weather station near Lizzie (MIMS) & $\begin{array}{l}\text { http://waterdata.usgs.gov/nc/nwis/nwisman/?site_no= } \\
\text { 0209173196\&agency_cd=USGS }\end{array}$ \\
\hline 353137077332801 & Weather station no. 2 near Lizzie & $\begin{array}{l}\text { http://waterdata.usgs.gov/nc/nwis/nwisman/?site_no= } \\
\text { 353137077332801\&agency_cd=USGS }\end{array}$ \\
\hline
\end{tabular}

\begin{tabular}{|c|c|c|}
\hline \multicolumn{3}{|c|}{ Ground-water stations } \\
\hline 353103077333401 & $\mathrm{~L} 2$ & http://waterdata.usgs.gov/nc/nwis/gwsi/?site_no=353103077333401 \\
\hline 353103077333402 & L2D & http://waterdata.usgs.gov/nc/nwis/gwsi/?site_no=353103077333402 \\
\hline 353103077333403 & L3 & http://waterdata.usgs.gov/nc/nwis/gwsi/?site_no=353103077333403 \\
\hline 353122077334901 & L4 & http://waterdata.usgs.gov/nc/nwis/gwsi/?site_no=353122077334901 \\
\hline 353122077334903 & L4D & http://waterdata.usgs.gov/nc/nwis/gwsi/?site_no=353122077334903 \\
\hline 353111077334401 & L5 & http://waterdata.usgs.gov/nc/nwis/gwsi/?site_no=353111077334401 \\
\hline 353111077334402 & L6 & http://waterdata.usgs.gov/nc/nwis/gwsi/?site_no=353111077334402 \\
\hline 353111077334404 & L6D & http://waterdata.usgs.gov/nc/nwis/gwsi/?site_no=353111077334404 \\
\hline 353111077334403 & L6S & http://waterdata.usgs.gov/nc/nwis/gwsi/?site_no=353111077334403 \\
\hline 353052077335501 & L9 & http://waterdata.usgs.gov/nc/nwis/gwsi/?site_no=353052077335501 \\
\hline 353135077332704 & L18D & http://waterdata.usgs.gov/nc/nwis/gwsi/?site_no=353135077332704 \\
\hline 353027077340102 & L20 & http://waterdata.usgs.gov/nc/nwis/gwsi/?site_no=353027077340102 \\
\hline 353051077333401 & L22 & http://waterdata.usgs.gov/nc/nwis/gwsi/?site_no=353051077333401 \\
\hline 353050077333401 & L23 & http://waterdata.usgs.gov/nc/nwis/gwsi/?site_no=353050077333401 \\
\hline 353050077333402 & $\mathrm{~L} 24$ & http://waterdata.usgs.gov/nc/nwis/gwsi/?site_no $=353050077333402$ \\
\hline 353042077334502 & $\mathrm{~L} 27$ & http://waterdata.usgs.gov/nc/nwis/gwsi/?site_no=353042077334502 \\
\hline 353142077332701 & L7 & http://waterdata.usgs.gov/nc/nwis/gwsi/?site_no $=353142077332701$ \\
\hline 353142077332702 & L8S & http://waterdata.usgs.gov/nc/nwis/gwsi/?site_no=353142077332702 \\
\hline 353142077332703 & L8D & http://waterdata.usgs.gov/nc/nwis/gwsi/?site_no $=353142077332703$ \\
\hline 353148077332101 & L10 & http://waterdata.usgs.gov/nc/nwis/gwsi/?site_no=353148077332101 \\
\hline
\end{tabular}


Appendix table 1. Data available for stations included in the Lizzie Research Station study.-Continued

\begin{tabular}{|c|c|c|}
\hline Site number & Station name & Web address \\
\hline \multicolumn{3}{|c|}{ Ground-water stations (continued) } \\
\hline 353148077332102 & L11D & http://waterdata.usgs.gov/nc/nwis/gwsi/?site_no=353148077332102 \\
\hline 353134077334601 & L12 & http://waterdata.usgs.gov/nc/nwis/gwsi/?site_no=353134077334601 \\
\hline 353127077333701 & L14 & http://waterdata.usgs.gov/nc/nwis/gwsi/?site_no=353127077333701 \\
\hline 353027077340101 & L19 & http://waterdata.usgs.gov/nc/nwis/gwsi/?site_no=353027077340101 \\
\hline 353042077334501 & L26 & http://waterdata.usgs.gov/nc/nwis/gwsi/?site_no=353042077334501 \\
\hline 353050077333403 & $\mathrm{~L} 25$ & http://waterdata.usgs.gov/nc/nwis/gwsi/?site_no=353050077333403 \\
\hline 353103077333406 & L55 & http://waterdata.usgs.gov/nc/nwis/gwsi/?site_no=353103077333406 \\
\hline 353137077334604 & GR148 & http://waterdata.usgs.gov/nc/nwis/gwsi/?site_no=353137077334604 \\
\hline 353153077333204 & GR152 & http://waterdata.usgs.gov/nc/nwis/gwsi/?site_no=353153077333204 \\
\hline 353153077333203 & GR151 & http://waterdata.usgs.gov/nc/nwis/gwsi/?site_no=353153077333203 \\
\hline 353153077333202 & GR150 & http://waterdata.usgs.gov/nc/nwis/gwsi/?site_no $=353153077333202$ \\
\hline 353153077333206 & GR153 & http://waterdata.usgs.gov/nc/nwis/gwsi/?site_no=353153077333206 \\
\hline
\end{tabular}


Appendix table 2. Ninety-five percent confidence intervals for annual loads and methods of load estimation used in the Lizzie Research Station study.

[Methods for load estimation: AMLE, Adjusted Maximum Likelihood Estimate; SUM, Sum of daily flows times mean concentrations for calendar year 2000; LAD, Least Absolute Deviation Method (cannot compute confidence interval with this method); LA, Linear Attribution Method (cannot compute confidence interval with this method)]

\begin{tabular}{|c|c|c|c|c|}
\hline Station name & $\begin{array}{c}\text { Total } \\
\text { nitrogen } \\
\text { load } \\
\text { (tons per year) }\end{array}$ & Lower 95\% & Upper 95\% & $\begin{array}{c}\text { Estimation } \\
\text { method }\end{array}$ \\
\hline \multicolumn{5}{|c|}{2000} \\
\hline Bear Creek at Mays Store & 201 & 182 & 221 & AMLE \\
\hline Neuse River at Kinston & 3,268 & 3,023 & 3,521 & AMLE \\
\hline Plum Tree Branch near Lizzie & 1.4 & 0.0 & 4.4 & SUM \\
\hline Sandy Run near Lizzie & 27 & & & LAD \\
\hline Middle Swamp near Farmville & 38 & 34 & 42 & AMLE \\
\hline Little Contentnea near Willow Green & 97 & & & LA \\
\hline Little Contentnea at Scuffleton & 160 & 139 & 184 & AMLE \\
\hline Contentnea Creek near Lucama & 139 & & & LAD \\
\hline Contentnea Creek near Evansdale & 526 & & & LA \\
\hline Nahunta Swamp near Shine & 109 & 95 & 123 & AMLE \\
\hline Contentnea Creek at Hookerton & 939 & 872 & 996 & AMLE \\
\hline Neuse River near Fort Barnwell & 4,192 & 3,722 & 4,703 & AMLE \\
\hline Trent River near Trenton & 207 & & & LAD \\
\hline Swift Creek near Streets Ferry & 508 & & & LAD \\
\hline \multicolumn{5}{|c|}{2001} \\
\hline Bear Creek at Mays Store & 150 & 134 & 167 & AMLE \\
\hline Neuse River at Kinston & 2,027 & 1,880 & 2,183 & AMLE \\
\hline Sandy Run near Lizzie & 11 & & & LAD \\
\hline Middle Swamp near Farmville & 17 & 15 & 19 & AMLE \\
\hline Little Contentnea near Willow Green & 51 & & & LA \\
\hline Little Contentnea at Scuffleton & 102 & 91 & 115 & AMLE \\
\hline Contentnea Creek near Lucama & 94 & & & LAD \\
\hline Contentnea Creek near Evansdale & 486 & & & LA \\
\hline Nahunta Swamp near Shine & 72 & 64 & 81 & AMLE \\
\hline Contentnea Creek at Hookerton & 622 & 588 & 657 & AMLE \\
\hline Neuse River near Fort Barnwell & 2,474 & 2,300 & 2,654 & AMLE \\
\hline Trent River near Trenton & 92 & & & LAD \\
\hline
\end{tabular}


Appendix table 2. Ninety-five percent confidence intervals for annual loads and methods of load estimation used in the Lizzie Research Station study.-Continued

[Methods for load estimation: AMLE, Adjusted Maximum Likelihood Estimate; SUM, Sum of daily flows times mean concentrations for calendar year 2000; LAD, Least Absolute Deviation Method (cannot compute confidence interval with this method); LA, Linear Attribution Method (cannot compute confidence interval with this method)]

\begin{tabular}{|c|c|c|c|c|}
\hline Station name & $\begin{array}{c}\text { Total } \\
\text { phosphorus } \\
\text { load } \\
\text { (tons per year) }\end{array}$ & Lower 95\% & Upper 95\% & $\begin{array}{c}\text { Estimation } \\
\text { method }\end{array}$ \\
\hline \multicolumn{5}{|c|}{2000} \\
\hline Bear Creek at Mays Store & 9.9 & 7.7 & 12 & AMLE \\
\hline Neuse River at Kinston & 294 & & & LA \\
\hline Plum Tree Branch near Lizzie & 0.0 & 0 & 0.1 & SUM \\
\hline Sandy Run near Lizzie & 4.4 & 3.2 & 5.4 & AMLE \\
\hline Middle Swamp near Farmville & 6.3 & 5.1 & 7.7 & AMLE \\
\hline Little Contentnea near Willow Green & 17 & 14 & 20 & AMLE \\
\hline Little Contentnea at Scuffleton & 26 & 22 & 30 & AMLE \\
\hline Contentnea Creek near Lucama & 7.2 & 5.4 & 8.8 & AMLE \\
\hline Contentnea Creek near Evansdale & 20 & 15 & 25 & AMLE \\
\hline Nahunta Swamp near Shine & 6.7 & & & LA \\
\hline Contentnea Creek at Hookerton & 88 & & & LAD \\
\hline Neuse River near Fort Barnwell & 313 & & & LA \\
\hline Trent River near Trenton & 34 & & & LA \\
\hline Swift Creek near Streets Ferry & 78 & 68 & 108 & AMLE \\
\hline \multicolumn{5}{|c|}{2001} \\
\hline Bear Creek at Mays Store & 8.9 & 6.2 & 12 & AMLE \\
\hline Neuse River at Kinston & 207 & & & LA \\
\hline Sandy Run near Lizzie & 1.8 & 1.3 & 2.6 & AMLE \\
\hline Middle Swamp near Farmville & 3.7 & 3.0 & 4.3 & AMLE \\
\hline Little Contentnea near Willow Green & 9.1 & 6.0 & 12 & AMLE \\
\hline Little Contentnea at Scuffleton & 20 & 18 & 23 & AMLE \\
\hline Contentnea Creek near Lucama & 3.6 & 2.8 & 4.3 & AMLE \\
\hline Contentnea Creek near Evansdale & 16 & 13 & 19 & AMLE \\
\hline Nahunta Swamp near Shine & 3.8 & & & LA \\
\hline Contentnea Creek at Hookerton & 67 & & & LAD \\
\hline Neuse River near Fort Barnwell & 232 & & & LA \\
\hline Trent River near Trenton & 9.1 & & & LA \\
\hline
\end{tabular}




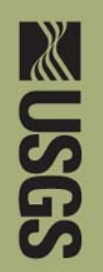

呈

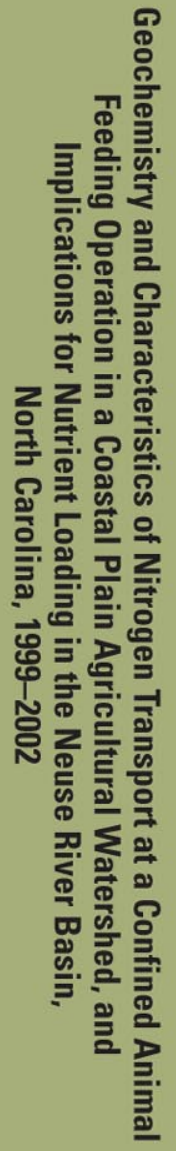

Printed on recycled paper

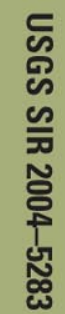

